\title{
UCRL-TR-213993
}

LAWRENCE LIVERMORE N A TIO N A L LABORATORY

Initial Radionuclide Inventories

H. Miller

July 26, 2005 
This document was prepared as an account of work sponsored by an agency of the United States Government. Neither the United States Government nor the University of California nor any of their employees, makes any warranty, express or implied, or assumes any legal liability or responsibility for the accuracy, completeness, or usefulness of any information, apparatus, product, or process disclosed, or represents that its use would not infringe privately owned rights. Reference herein to any specific commercial product, process, or service by trade name, trademark, manufacturer, or otherwise, does not necessarily constitute or imply its endorsement, recommendation, or favoring by the United States Government or the University of California. The views and opinions of authors expressed herein do not necessarily state or reflect those of the United States Government or the University of California, and shall not be used for advertising or product endorsement purposes.

This work was performed under the auspices of the U.S. Department of Energy by University of California, Lawrence Livermore National Laboratory under Contract W-7405-Eng-48. 
QA: QA

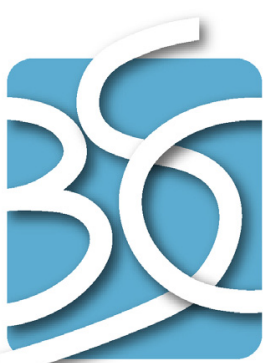

BECHTEL SAIC COMPANYLC

ANL-WIS-MD-000020 REV 01

September 2004

\section{Initial Radionuclide Inventories}

Prepared for:

U.S. Department of Energy

Office of Civilian Radioactive Waste Management

Office of Repository Development

1551 Hillshire Drive

Las Vegas, Nevada 89134-6321

Prepared by:

Bechtel SAIC Company, LLC

1180 Town Center Drive

Las Vegas, Nevada 89144

Under Contract Number

DE-AC28-01RW12101 
ANL-WIS-MD-000020 REV 01 
QA: QA

Initial Radionuclide Inventories

ANL-WIS-MD-000020 REV 01

September 2004 


\section{Scientific Analysis Title}

\section{Initial Radionuclide Inventories}

3. DI (including Revision Number)

ANL-WIS-MD-000020 REV 01

4. Total Appendices

Five (5)

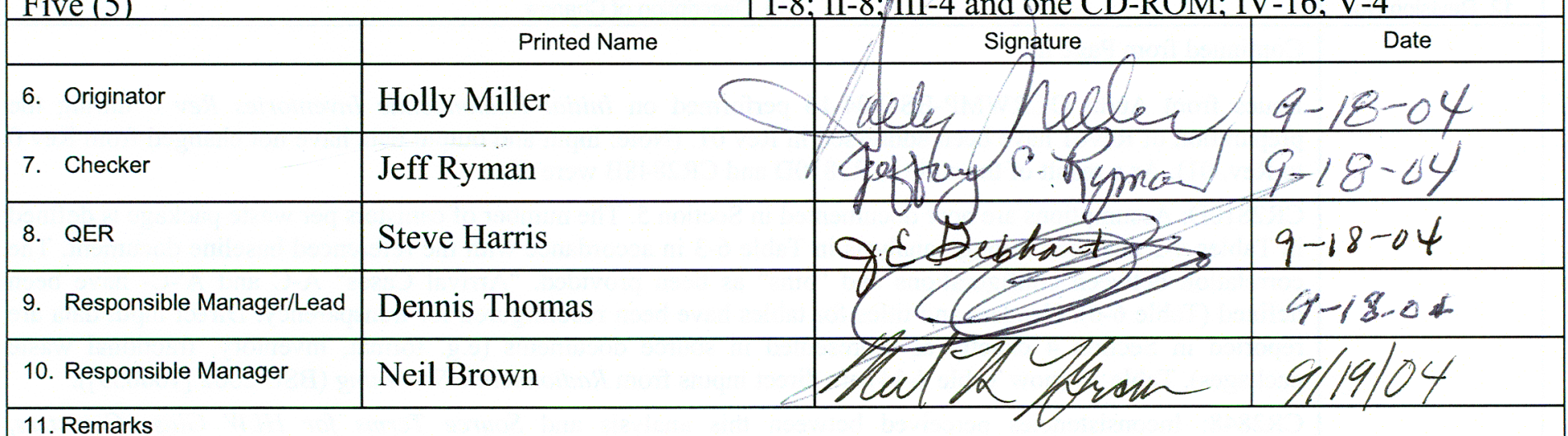

11. Remarks

\section{Change History}

Initial Issue. This analysis updates and supercedes the following analyses performed for the Total System Performance Assessment for the Site Recommendation:

Update:

- Inventory Abstraction (ANL-WIS-MD-000006 REV 00 ICN 03, Attachments I \& II only). REV 00, ICN 03 of Inventory Abstraction (ANL-WIS-MD-000006) was superceded by REV 1 of that document. The scope of Attachments I \& II of ANL-WIS-MD-000006 REV $00 \mathrm{ICN} 03$ were not
transferred to this document. Attachment II is updated here as Attachment I.

Supercede:

- Waste Package Radionuclide Inventory Approximations for TSPA-SR (CAL-WIS-MD-000004 REV 00 ICN 01)

- Per Canister Inventories for DOE SNF for TSPA-SR (CAL-WIS-MD-000006 REV 00).

Revision 01 is a complete revision to address comments from reviews, audits and/or assessments, address/resolve TBVs and CRs as applicable, and update the document to comply with revised OCRWM procedures and plans, as appropriate, governing the preparation of analyses. Change bars were not used because the changes were too extensive.

CR79B has been addressed by appropriate designation and treatment of document inputs in accordance with AP-3.15Q (including but not limited to removing input designations of "technical information" in DIRS to meet new AP.15Q input descriptions.)

CR 2478B: no data were used as direct input from DOE/RW-0184. Tables in the DOE 1987 report, labeled Fuel Assembly Hardware Parts and Materials, are referred to as general corroborative information to the primary input reference (BSC 2004 [DIRS 170879]) for materials specifications for CSNF assembly hardware as discussed in Appendix I of this analysis. 


\section{Scientific Analysis Change History (CONTINUED)}

2. Scientific Analysis Title

Initial Radionuclide Inventories

3. DI (including Revision Number)

ANL-WIS-MD-000020 REV 01

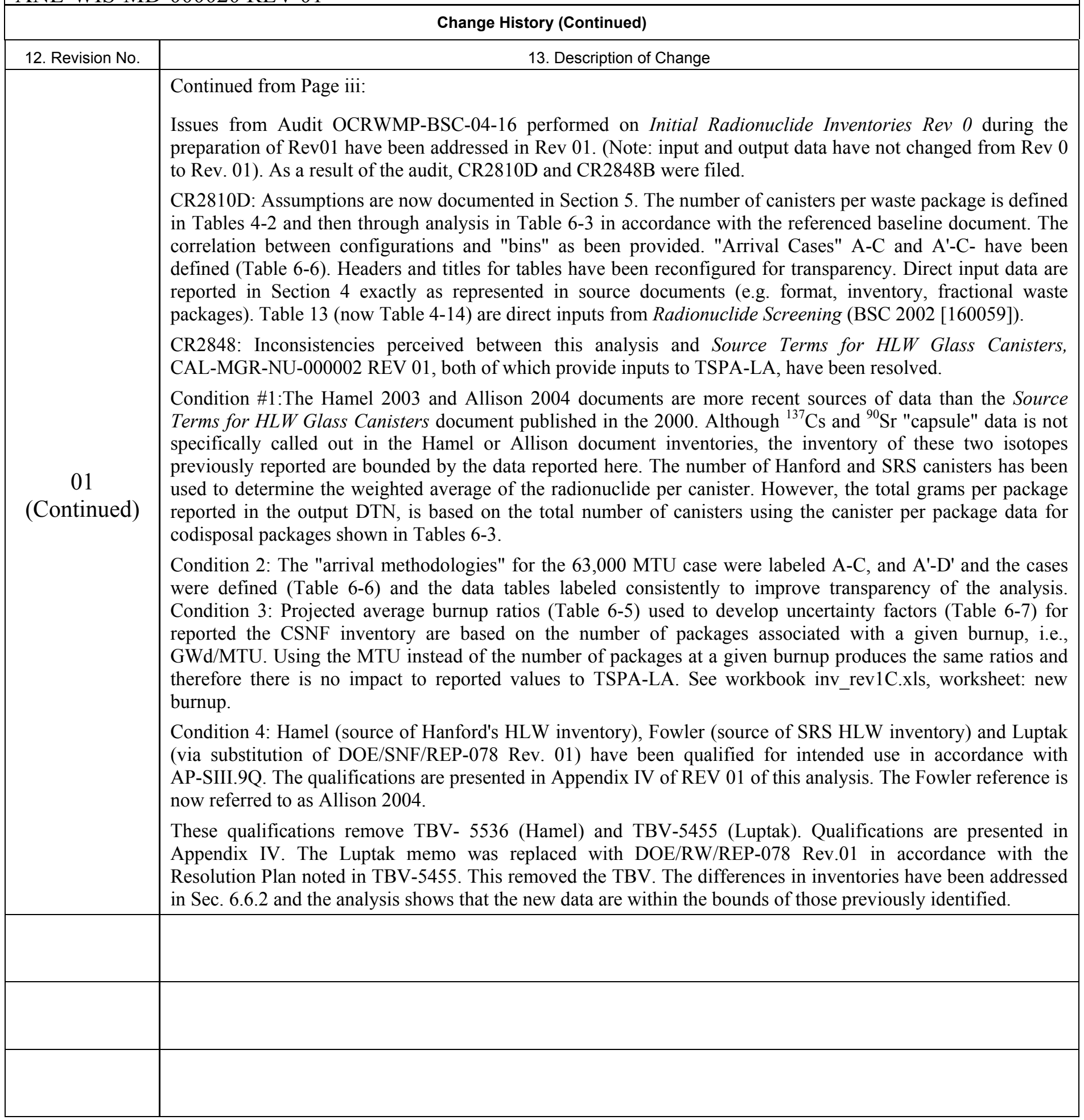




\section{CONTENTS}

Page

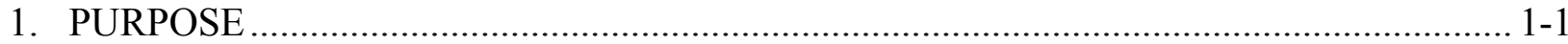

1.1 STUDY LIMITATIONS AND CONSIDERATIONS ……….............................. 1-2

1.2 YUCCA MOUNTAIN PROJECT DOCUMENTS PROVIDING INPUT TO THIS ANALYSIS .................................................................................................... 1-3

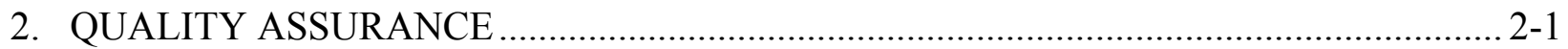

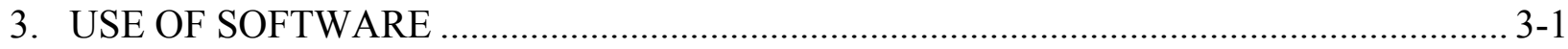

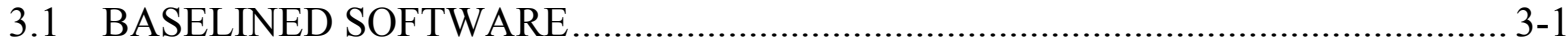

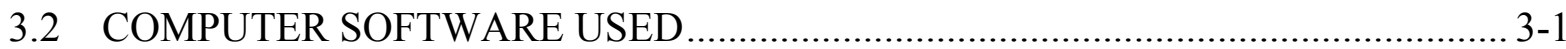

4. INPUTS

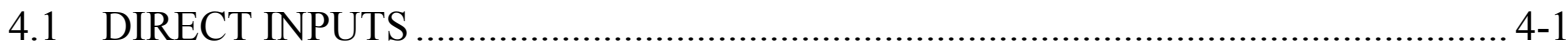

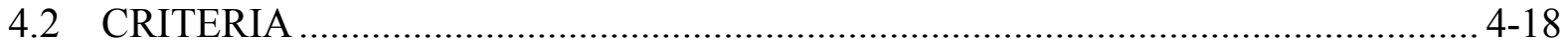

4.3 CODES, STANDARDS, AND REGULATIONS .................................................. 4-19

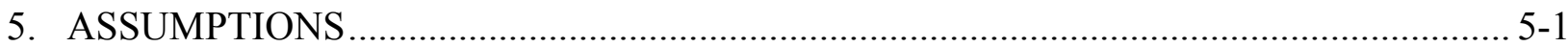

5.1 COMMERCIAL SPENT NUCLEAR FUEL ……............................................ 5-1

5.2 DOE-OWNED SPENT NUCLEAR FUEL …….................................................... 5-1

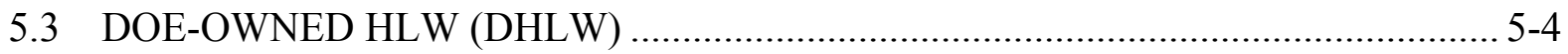

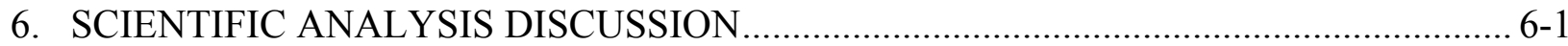

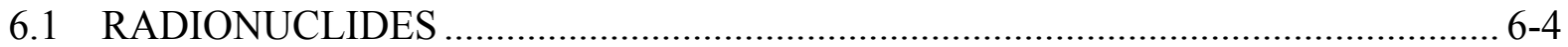

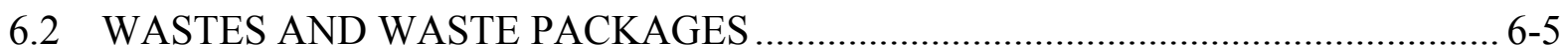

6.3 FEATURES, EVENTS, AND PROCESSES CONSIDERED IN THE

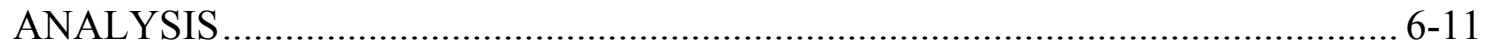

6.4 APPROACH AND METHODS OF CALCULATIONS ……………................... 6-12

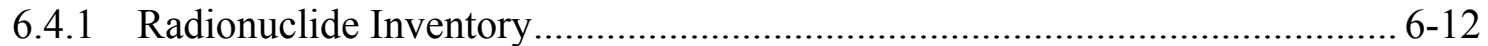

6.4.2 Inventory Heterogeneity ......................................................................... 6-12

6.4.3 Radionuclide Analysis of Activated Mineral Deposits on Assemblies .......... 6-13

6.5 RADIONUCLIDE INVENTORY ANALYSES RESULTS ................................... 6-13

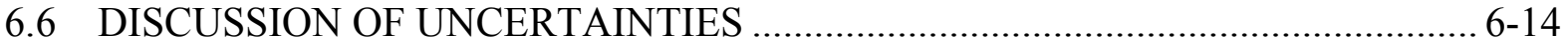

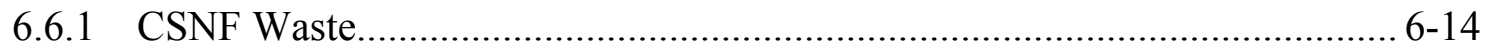

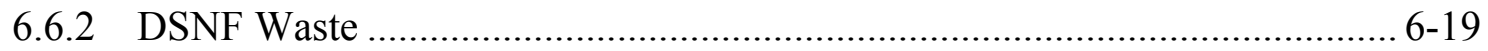

6.6.3 HLW Glass Waste................................................................................ 6-22

6.7 INTENDED USE OF OUTPUT DATA ……………………………………... 6-25

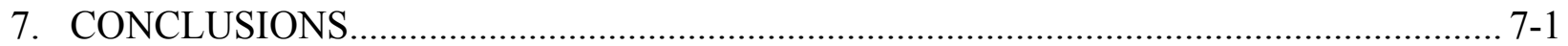

7.1 INITIAL RADIONUCLIDE INVENTORIES .........................................................

7.2 YUCCA MOUNTAIN REVIEW PLAN ACCEPTANCE CRITERIA ……………..... 7-3 


\section{CONTENTS}

Page

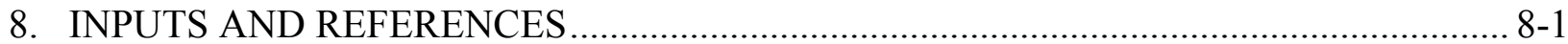

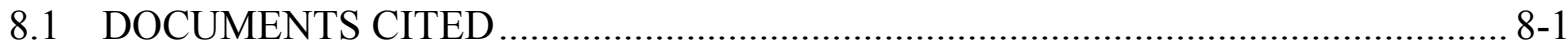

8.2 CODES, STANDARDS, REGULATIONS, AND PROCEDURES ........................... 8-5

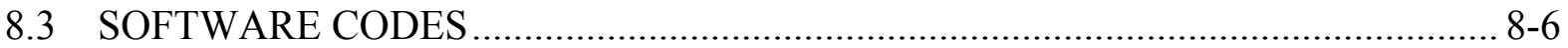

8.4 SOURCE DATA, LISTED BY DATA TRACKING NUMBER ………………........ 8-7

APPENDIX I. NEUTRON-ACTIVATION PRODUCTS OUTSIDE THE SPENTFUEL MATRIX....................................................................................

APPENDIX II. DESCRIPTION OF FILES ON CD ……................................................... II-1

APPENDIX III. WORKSHEETS AND PLOTS IN INV_REV1.XLS ................................... III-1 APPENDIX IV. QUALIFICATION OF UNQUALIFIED DATA USED AS DIRECT

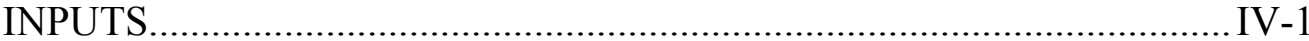

APPENDIX V. DATA QUALIFICATION PLAN ……………………............................ V-1 


\section{FIGURES}

Page

6-1. Various Waste Package Types Containing Different Wastes....................................... 6-7

6-2. Some Waste Package Configurations for CSNF, DSNF, Naval, and HLW Glass .......... 6-8

6-3. Histograms of Waste Package Configurations ......................................................... 6-11

6-4. $\quad$ Average Grams per Package of Radionuclides for Each Waste Type ........................ 6-13

6-5. Comparison of the Per-Package Inventories of the Five CSNF Configurations .......... 6-16

6-6. Ratios of CSNF Configuration Inventories to the CSNF Weighted Average .............. 6-17

6-7. Uncertainty in 2003 DSNF Radionuclide Inventory Estimates ............................... 6-20

6-8. Comparison of the Nominal Radionuclide Inventory for 2003 (old nom) and 2004 (new nom) ................................................................................................ 6-21

6-9. Comparison of the 2003 and 2004 DSNF Radionuclide Inventories ......................... 6-22

6-10. Radionuclide Inventories of the Older and Newer Estimates for Average Short and Long HLW Glass Canisters .......................................................................... 6-24

6-11. SRS Glass Batch Inventories ...................................................................... 6-24 


\section{INTENTIONALLY LEFT BLANK}




\section{TABLES}

Page

4-1. Direct Inputs Used in This Report

4-2. Waste Package Configurations and Inventory Information - Nominal Quantity for LA.....

4-3. Constants Used in Calculations

4-4. Average Radionuclide Inventory (Curies/Assembly) for Each CSNF Waste Package Configuration at the Projected Year of Repository Emplacement (2033) for 63,000 MTU, Case A

4-5. 63,000 MTU Waste Package Burnup Characteristics Based on 1999 CSNF Waste Streams.

4-6. CSNF Assembly Totals and Burnup Characteristics for the 63,000 MTHM Cases Based on 2002 CSNF Waste Streams ....................................................................... 4-6

4-7. Summary of Percent Differences between Calculated and Computed Compositions ..... 4-7

4-8. Nominal and Bounding Radionuclide Inventories for DSNF Canisters .......................... 4-9

4-9. New Estimated Curies Per Canister for Savannah River Site (SRS) HLW (Batches

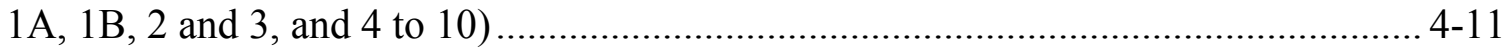

4-10. Estimated Radioactivity in the Hanford HLW Canisters at Decay Date of 2030.......... 4-12

4-11. Hanford HLW Canister Production Estimates for Alternative Canister Wastes Loading and Canister Fill Levels............................................................................ 4-12

4-12. Radionuclide Half-Lives ............................................................................. 4-13

4-13. Results of the Screening Analysis......................................................................... 4-14

4-14. Additional Radionuclides Needed for Accurate Accounting of Those Screened In for 10,000 Years................................................................................................... 4-15

4-15. Identification and Screening Status of CSNF PWR and BWR Hardware-Activation

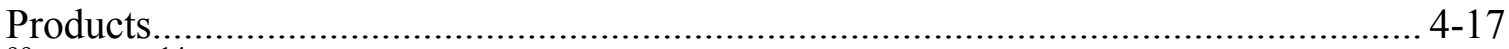

4-16. ${ }^{99} \mathrm{Tc}$ and ${ }^{14} \mathrm{C}$ Inventories of BWR Assembly at Specified Characteristics ................... 4-18

5-1. Assumptions Related to DSNF ............................................................................ 5-2

6-1. Precursors Identified as Significant to the Regulatory Period for TSPA-LA.................. 6-5

6-2. Included Radionuclides (32) ............................................................................ 6-5

6-3. Package Configurations Including New Waste Codisposal Packages to Accommodate DSNF ${ }^{\mathrm{a}}$

6-4. Features, Events, and Processes Included (Screened In) in TSPA-LA and Addressed

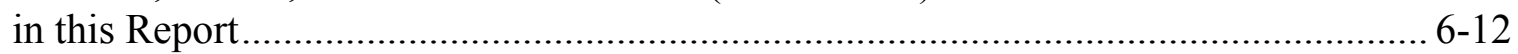

6-5. Average Burnups for the 5 CSNF Configurations, and Ratios to Average ................... 6-16

6-6. Arrival Forecasts for the 63,000 MTU ............................................................ 6-18

6-7. Average Burnups for the Arrival Scenarios Projected For Years 1999 And 2002 2....... 6-19

7-1. Nominal Grams per Waste Package of Radionuclides for Each Type of Waste ............. 7-2

7-2. Uncertainty Multipliers for Grams per Package of Radionuclides for Each Waste Type 
INTENTIONALLY LEFT BLANK 


\section{ACRONYMS}

AP absorber plates

BOL beginning of life

BSC Bechtel SAIC Company, LLC

BWR boiling water reactor

CDSP codisposal

CSNF commercial spent nuclear fuel

CR control rods

DOE U.S. Department of Energy

DHLW DOE owned high-level (radioactive) waste

DSNF DOE owned spent nuclear fuel

EIS Environmental Impact Statement

EOC end of cycle

EOL end of life

EPRI Electric Power Research Institute

FEIS Final Environmental Impact Statement

FEP feature, event, or process

FEPs features, events, and processes

HLW high-level (radioactive) waste

INEEL Idaho National Engineering and Environmental Laboratory

LA License Application

MCO multi-canister overpack

MTHM metric tons of heavy metal

MTU metric tons of uranium

PWR pressurized water reactor

SNF spent nuclear fuel

SNFID spent nuclear fuel identification

SR Site Recommendation

SRS Savannah River Site

TSPA Total System Performance Assessment

TSPA-LA Total System Performance Assessment - License Application 
INTENTIONALLY LEFT BLANK 


\section{PURPOSE}

The purpose of this analysis is to provide an initial radionuclide inventory (in grams per waste package) and associated uncertainty distributions for use in the Total System Performance Assessment for the License Application (TSPA-LA) in support of the license application for the repository at Yucca Mountain, Nevada. This document is intended for use in postclosure analysis only.

Bounding waste stream information and data were collected that capture probable limits. For commercially generated waste, this analysis considers alternative waste stream projections to bound the characteristics of wastes likely to be encountered using arrival scenarios that potentially impact the commercial spent nuclear fuel (CSNF) waste stream. For TSPA-LA, this radionuclide inventory analysis considers U.S. Department of Energy (DOE) high-level radioactive waste (DHLW) glass and two types of spent nuclear fuel (SNF): CSNF and DOEowned (DSNF). These wastes are placed in two groups of waste packages: the CSNF waste package and the codisposal waste package (CDSP), which are designated to contain DHLW glass and DSNF, or DHLW glass only. The radionuclide inventory for naval SNF is provided separately in the classified Naval Nuclear Propulsion Program Technical Support Document for the License Application.

As noted previously, the radionuclide inventory data presented here is intended only for TSPA-LA postclosure calculations. It is not applicable to preclosure safety calculations. Safe storage, transportation, and ultimate disposal of these wastes require safety analyses to support the design and licensing of repository equipment and facilities. These analyses will require radionuclide inventories to represent the radioactive source term that must be accommodated during handling, storage and disposition of these wastes. This analysis uses the best available information to identify the radionuclide inventory that is expected at the last year of last emplacement, currently identified as 2030 and 2033, depending on the type of waste. TSPA-LA uses the results of this analysis to decay the inventory to the year of repository closure projected for the year of 2060 .

The radionuclides of importance to TSPA-LA dose calculations were assessed in Radionuclide Screening (BSC 2002 [DIRS 160059]). The radionuclide screening analysis separately considered the following two postclosure time periods: the 10,000-year regulatory period for the repository at Yucca Mountain, and the period of up to one million years after emplacement identified in Final Environmental Impact Statement (FEIS) (DOE 2002 [DIRS 155970], Section 6.3). Four release scenarios were considered: (1) nominal, (2) human-intrusion, (3) intrusive igneous event, and (4) eruptive igneous event. Table 13 of the screening analysis (Table 4-13) identifies those isotopes that contribute 95 percent of the dose for the different scenarios implemented in the TSPA-LA for the 10,000-year regulatory period (columns 2 and 4 ) and for the FEIS period of one million years (columns 3 and 5). The screening document also indicated that a separate Environmental Protection Agency (EPA) groundwater protection standard (40 CFR 197.30 [DIRS 165519]) required ${ }^{228} \mathrm{Ra}$ be added to the list. Precursors of the screenedin isotopes due to radioactive decay and in-growth were identified for consideration (Table 4-14) (BSC 2002 [DIRS 160059], Table 12). Precursors must be considered for inclusion in TSPA-LA, either by direct inclusion or by appropriate augmentation of the daughter product. Based on this premise, this analysis identifies seven precursors for the 21 radionuclides identified as significant 
to the regulatory period (Table 6-1). These have been added to the inventory for TSPA-LA postclosure analysis. Thus, a total of 28 radionuclides for the 10,000-year regulatory period and an additional four important to the million-year FEIS calculations are identified for TSPA-LA (Tables 6-2 and 7-1). The screening document notes that extending the screening to 20,000 years adds no radionuclides to the lists (DOE 2002 [DIRS 155970]).

This analysis was prepared in accordance with Technical Work Plan for: Regulatory Integration Modeling and Analysis of the Waste Form and Waste Package (BSC 2004 [DIRS 171583]). This analysis provides information and data to support the technical basis for the waste-form representation in the TSPA-LA as it relates to the initial radionuclide inventory at the projected time of emplacement. The technical work plan defines the scope of this report and identifies the regulatory and acceptance criteria to be addressed in this analysis. There were no deviations from the technical work plan. In addition, the guidance provided in Total System Performance Assessment-License Application Methods and Approach (BSC 2003 [DIRS 166296]) has been used in the preparation of this analysis as applicable. Acceptance criteria related to Section 2.2.1.3.4 of Yucca Mountain Review Plan, Final Report (NRC 2003 [DIRS 163274]) are addressed in this report, as identified in Table 3-1 of Technical Work Plan for: Regulatory Integration Modeling and Analysis of the Waste Form and Waste Package (BSC 2004 [DIRS 171583]).

\subsection{STUDY LIMITATIONS AND CONSIDERATIONS}

As required by the Nuclear Waste Policy Act, as amended (NWPA 1987 [DIRS 100016]), the DOE must dispose of all under-contract CSNF and HLW and all government-managed SNF and HLW (BSC 2003 [DIRS 165990]). This analysis addresses the "base case" for CSNF currently allocated (63,000 MTHM CSNF and 7,000 MTHM government-managed (DOE-owned) waste) in accordance with the legal-limit imposed by the Nuclear Waste Policy Act, as amended (NWPA 1987 [DIRS 100016]).

DSNF includes diverse fuels from various experimental, research, and production reactors and consists of several hundred different fuel types that have been stored at several sites (DOE 2003 [DIRS 163377], p. 14). Because much of the available data for these fuels is historical, a process for creating a conservative estimate of the DSNF source terms was developed. The process relies on data used to provide radionuclide inventories for typical SNFs at a range of decay times. These results used ORIGEN-based calculational techniques to develop "templates" scaled to estimate the radionuclide inventory of other similar fuels. Several validation studies have been performed to demonstrate the validity of the model and underlying codes used (DOE 2004 [DIRS 169354], p.14). The National Spent Nuclear Fuel Program consolidates DSNF information and makes it available to support DOE planning and scoping activities as well as design and licensing efforts to enable final repository disposal of DSNF. This source (used as input to this analysis) provides radionuclide inventory data for all DSNF destined for the repository except for naval SNF.

Among the government-managed wastes, naval SNF (which is part of the DSNF MTHM repository allocation) represents a very small percentage of the nuclear waste expected for the repository (BSC 2003 [DIRS 165990] p. xix). Details regarding the design and performance of naval SNF are provided separately in the classified Naval Nuclear Propulsion Program 
Technical Support Document and are not part of this analysis. Naval SNF waste packages (total long and short canisters) have been reported as an "upper bound" of 300 (McKenzie 2001 [DIRS 158051]) and have been included in the number of CSNF waste packages.

The CSNF bare fuel in DOE's possession in not included in this analysis. Source Term Estimates for Spent Nuclear Fuels (DOE 2003 [DIRS 163377]) provides the inventory for DSNF. This analysis excludes that part of the inventory associated with bare fuel and assumes that the remaining inventory is conservative for TSPA-LA calculations. The basis for this assumption is provided in Section 5.2. The repository allotment for DSNF including naval fuel is 2,333 MTHM (Dreyfus 1995 [DIRS 104384]; Lytle 1995 [DIRS 104398]). The repository allocation for naval fuel is 65 MTHM, leaving an allotment of 2,268 MTHM for DSNF. The DSNF inventory (2,348 metric tons of ${ }^{238} \mathrm{U}$ ), excluding the bare fuel inventory (48 metric tons of ${ }^{238} \mathrm{U}$ ), exceeds the repository allotment for DSNF $(2,348-48=2,300$, which is greater than 2,268). Therefore, using the DSNF radionuclide inventory reported in Source Term Estimates for Spent Nuclear Fuels (DOE 2003 [DIRS 163377]), excluding the bare fuel produces a conservative DSNF inventory for TSPA-LA.

Information in this analysis is based on projections of future events. Therefore, it is recognized that there may be wastes with characteristics different from those described in this document. The DOE will accommodate, through operational adjustments and design flexibility, a wide range of transport and arrival sequences, packaging configurations, and waste forms. This analysis takes into consideration these parameters and uses the data as input, understanding that future analyses or models may define them differently in the future.

\subsection{YUCCA MOUNTAIN PROJECT DOCUMENTS PROVIDING INPUT TO THIS ANALYSIS}

Several documents produced by the Yucca Mountain Project provide direct inputs to this report (BSC 2002 [DIRS 160059]; BSC 2003 [DIRS 165990], Tables 2 and 4; CRWMS M\&O 2000 [DIRS 138239]). 
INTENTIONALLY LEFT BLANK 


\section{QUALITY ASSURANCE}

This document was developed in accordance with Section 8 of Technical Work Plan for: Regulatory Integration Modeling and Analysis of the Waste Form and Waste Package (BSC 2004 [DIRS 171583]). The technical work plan indicates that this analysis is subject to the Yucca Mountain Project quality assurance program (DOE 2004 [DIRS 171539]) because it will be used to support the TSPA-LA. This document is subject to Quality Assurance Requirements Description (DOE 2004 [DIRS 171539]) requirements.

AP-SIII.9Q, Scientific Analyses, was primarily followed in developing this document. Data used as direct input to this analysis are qualified for intended use in accordance with AP-SIII.2Q, Qualification of Unqualified Data; AP-3.15Q, Managing Technical Product Inputs; and AP-SIII.9Q, Scientific Analyses. The qualification plans and reports are documented in Appendix IV. The signed originals of the data qualification plans are included in the record package for this analysis.

Technical Work Plan for: Regulatory Integration Modeling and Analysis of the Waste Form and Waste Package (BSC 2004 [DIRS 171583]) includes an evaluation of current work processes and procedures in accordance with AP-SV.1Q, Control of the Electronic Management of Information. This evaluation determined that the work conducted under this technical work plan require controls for the electronic management of information. This analysis activity does not involve sensitive unclassified information and, therefore, controls for that purpose were not implemented. Controls to protect information from damage or destruction for its prescribed lifetime include dual electronic storage on individual hard drives and a network drive with remote backup each night to a secure drive. These systems also ensure that information is readily retrievable.

The BSC Intranet includes several controlled databases for the storage of data, program documents, procedures, reports, models, analyses, etc. to ensure information is accurate and readily available (e.g., OCRWM Program Documents Database (OPDD), Document Information Reference System (DIRS), Records Information System (RIS), Automated Technical Data Tracking system (ATDT)). These systems, in conjunction with procedures, ensure that data or information inputs are from controlled sources and changes to input (data, documents, and design information) undergo the same level of control as the original. Access to controlled information is limited to authorized users through password protection. These system-specified design parameters define how the information will be stored with respect to media, conditions, location retention time, security, and access. They also provide controls to properly identify storage and transfer media as to source, physical and logical format, size, and relevant date.

With respect to analyses, AP-SIII.9Q, Scientific Analyses ensures documents address content determined important to TSPA-LA. AP-17.1Q, Records Management, and AP-6.1Q, Document Control, ensure documents and records are controlled and complete, specify controls for changes to documents, and define retention requirements for records. To ensure transfers of information are error free or within a defined permissible error rate, sum checks after transfers or visual checks of file information (such as file size, date and time, and file names) are used. These checks and the following procedural controls provide adequate controlled access to maintain the security and integrity of the information and ensure transfers of information are error free or 
within a defined permissible error rate. AP-3.15, Managing Technical Product Inputs; AP-SIII.2Q Qualification of Unqualified Data; and AP-SIII.3Q, Submittal and Incorporation of Data to the Technical Data Management System are some examples. All data used as direct input to develop the results or conclusions in this analysis are qualified in accordance with AP-SIII.2Q, Qualification of Unqualified Data, AP-3-15Q, Managing Technical Product Inputs, or AP-SIII.9Q, Scientific Analyses. AP-SIII.2Q and AP-SIII.9Q provide criteria and processes for the qualification of data for its intended use within a technical product.

Controls are also implemented that include the use of InfoWorks software. InfoWorks is a BSC project-wide control, for version control implemented during the preparation and editing of this analysis. Access to documents and subsequent drafts using InfoWorks is password protected. Visual checks were performed to ensure data used in this analysis has been documented accurately and completely in Design and Engineering (D\&E) Information Exchange Drawings (IEDs). IEDs are prepared for data used in analyses and model reports that originate from Design and Engineering (D\&E) calculations. This IED "process" includes a Technical Management Review Board review and approval of a "decision proposal" and copy of the IED. The data selected is at the author's discretion.

This report does not directly impact structures, systems, or components classified in accordance with AP-2.22Q, Classification Analyses and Maintenance of the Q-List. 


\section{USE OF SOFTWARE}

\subsection{BASELINED SOFTWARE}

No controlled and baselined software subject to Section 2.2 of LP-SI.11Q-BSC, Software Management, was used in the creation of this document.

\subsection{COMPUTER SOFTWARE USED}

The calculations performed in this analysis used commercially available, off-the-shelf software (Microsoft Excel 97). Use of Microsoft Excel is considered appropriate because a) the calculations require simple mathematical expressions for deriving the final results, which are standard operations in Microsoft Excel, and b) Microsoft Excel has built-in graphical charting capabilities. No software routines or macros are developed in this use of Microsoft Excel. Calculations and the use of inputs are discussed in Sections 4 and 6. Details of the workbook and worksheet calculations and the corresponding mathematical expressions are given in Appendix II. Appendix III is a CD containing the Microsoft Excel file inv_rev1.xls. Workbook and worksheet names will be denoted in Courier font throughout this document. 
INTENTIONALLY LEFT BLANK 


\section{INPUTS}

\subsection{DIRECT INPUTS}

This section addresses the inputs directly used to develop the initial radionuclide inventory for input to TSPA-LA. Table 4-1 provides a brief description of data used as direct input, its location in this document, and the data source. Figure II-1 provides a graphical depiction of the flow of the analysis and the use of inputs. Equations that are used in this analysis are simple arithmetic operations (multiplication, division, addition, and unit conversions) and are discussed in the context of presenting the use of inputs for analysis development in Section 6. Appendices II and III provide further illustration of these operations.

To determine the average grams per package for the radionuclide inventory expected at the end of emplacement, calculations using several data inputs are needed. For the purpose of this analysis, the inventory considers DHLW glass and the three types of SNF: CSNF, DSNF, and naval SNF. These wastes are distributed in two groups of waste packages: (1) the CSNF waste packages (which include naval waste packages for the purposes of the analysis only), and (2) the codisposal waste package, which contains DSNF and DHLW glass or only DHLW glass.

Table 4-2 identifies waste package configurations and the nominal quantity of waste packages assigned to each configuration for TSPA-LA (BSC 2004 [DIRS 169472], Table 11). To facilitate the transparency of this analysis, waste package configurations identified in Table 11 of $D \& E / P A / C$ IED Typical Waste Package Components Assembly (BSC 2004 [DIRS 169472]) are described (type of waste package for each configuration is identified) and a number is assigned that correlates with the analysis performed as described in Section 6.

The lists of radionuclides determined to be significant to TSPA-LA dose calculations were identified in Radionuclide Screening (BSC 2002 [DIRS 160059], Tables 12 and 13). Table 4-13 shows the 20 radionuclides "screened in" that contribute to 95 percent of the dose for the scenarios implemented in the TSPA-LA. The radionuclides screened in for the 10,000-year regulatory period after emplacement are shown in columns 2 and 4 . The radionuclides identified for the FEIS millionyear period are shown in columns 3 and 5 (BSC 2002 [DIRS 160059], Table 13). This list includes ${ }^{228} \mathrm{Ra}$, which was added to comply with EPA's groundwater protection standard. Radionuclide Screening (BSC 2002 [DIRS 160059] identified three radionuclides that are precursors of "screened in" radionuclides for consideration, to be added directly to the inventory or added by augmentation of the daughter product (Table 4-14). This analysis identifies seven radionuclides (Table 6-1) that are precursors to "screened in" isotopes to be included in the inventory for the regulatory period. Thus, $20+1+7$ radionuclides are identified for the 10,000-year regulatory period. The addition of four radionuclides for the FEIS million-year period results in the final list of 32 radionuclides for TSPA-LA analysis (Tables 6-2 and 7-1). Table 7-1 shows the nominal radionuclide inventory in grams per radionuclide per waste package at the projected year of final emplacement) (DTN: SN0310T0505503.004) for 32 radionuclides.

To determine $\mathrm{g} / \mathrm{Ci}$ (grams per curie), Equation II-1 (Appendix II) is used. The mass per activity $\left(\mathrm{m}_{\mathrm{i}} / \mathrm{a}_{\mathrm{i}}\right)$ in $\mathrm{g} / \mathrm{Ci}$ for each of 32 radionuclides (i) from Table 6-2 is calculated using constants from Parrington et al. (1996 [DIRS 103896]). The latest half-life for ${ }^{79} \mathrm{Se}$ was taken from "Nuclear Data Sheets for A = 79" (Singh 2002 [DIRS 164741], p. 1). The molecular weights $\left(\mathrm{MW}_{\mathrm{i}}\right)$ (in g/mole) were taken from the radionuclide names because that value had enough significant figures for these purposes. 
Table 4-1. Direct Inputs Used in This Report

\begin{tabular}{|c|c|c|c|c|}
\hline \multicolumn{2}{|c|}{ Data/Technical Information } & Values/Table & Units & Source \\
\hline \multirow{2}{*}{$\begin{array}{l}\text { Waste } \\
\text { Package } \\
\text { Configuration }\end{array}$} & $\begin{array}{l}\text { Number of packages for each } \\
\text { configuration }\end{array}$ & Table 4-2 & Packages & BSC 2004 [DIRS 169472], Table 11 \\
\hline & $\begin{array}{l}\text { Number of canisters or assemblies } \\
\text { per package }\end{array}$ & Table 4-2 & $\begin{array}{l}\text { Canisters / } \\
\text { Assemblies }\end{array}$ & BSC 2004 [DIRS 169472], Table 11 \\
\hline & $\begin{array}{l}\text { Average CSNF radionuclide } \\
\text { inventory in } 2033 \text { for each of the } 5 \\
\text { WP configurations (Bins 1-5) for } \\
\text { Case A-63,000 MTU scenario } \\
\text { based on } 1999 \text { CSNF waste } \\
\text { streams. }\end{array}$ & Table 4-4 & $\begin{array}{l}\text { Curies per } \\
\text { radionuclide } \\
\text { per } \\
\text { assembly } \\
\text { (Bins 1-5) }\end{array}$ & $\begin{array}{l}\text { CRWMS M\&O } 2000 \text { [DIRS 138239], } \\
\text { from Disk I, Attachment III, File } \\
\text { D:IBIN.EXE_Filesloutput_filesICase_ } \\
\text { A_63Klaverage_nuclides.dat. Also, } \\
\text { see (CD for this analysis): workbook } \\
\text { CSNFcasea63.xls }\end{array}$ \\
\hline & $\begin{array}{l}\text { Average Initial Burnup values for } \\
63,000 \text { MTU (63K) Cases A-C } \\
\text { (Arrival scenarios) for the } 5 \text { WP } \\
\text { configurations; number of waste } \\
\text { packages for each waste package } \\
\text { design }\end{array}$ & Table 4-5 & $\begin{array}{l}\text { Burnup in } \\
\text { GWd/MTU }\end{array}$ & $\begin{array}{l}\text { CRWMS M\&O 2000 [DIRS 138239] } \\
\text { Tables 10, 12, 14; p. } 18\end{array}$ \\
\hline & $\begin{array}{l}\text { Total Number of PWR\&BWR } \\
\text { Assemblies and burnup values for } \\
63 \mathrm{~K} \text {, Cases A' to D' (Arrival } \\
\text { scenarios) }\end{array}$ & Table 4-6 & $\begin{array}{l}\text { Burnup in } \\
\text { units of } \\
\text { GWd/MTM }\end{array}$ & BSC 2003 [DIRS 165990], Table 2 \\
\hline & $\begin{array}{l}\text { BWR \& PWR burnup values for the } \\
\text { 63K MTHM Cases (Arrival } \\
\text { scenarios A' to } D^{\prime} \text { ) }\end{array}$ & Table 4-6 & GWd/MTU & BSC 2003 [DIRS 165990], Table 4 \\
\hline & $\begin{array}{l}\text { Modeled Calculation of Uncertainty } \\
\text { for CSNF }\end{array}$ & $\begin{array}{l}\text { Table 4-7 } \\
\text { Section } 6.6 .1\end{array}$ & None & $\begin{array}{l}\text { DeHart and Hermann } 1996 \\
\text { [DIRS 156084], Table } 19 \\
\text { Hermann and DeHart } 1998 \\
\text { [DIRS 106563], Table 24 } \\
\end{array}$ \\
\hline & Isotopes Required by EPA \& NRC & ${ }^{228} \mathrm{Ra}^{226} \mathrm{Ra}$ & none & $\begin{array}{l}\text { 40 CFR 197.30 [DIRS 165519] and } \\
\text { 10 CFR 63.331 [DIRS 156605] for } \\
\text { groundwater protection }\end{array}$ \\
\hline & DSNF inventory & Table 4-8 & $\begin{array}{l}\text { Curies/ } \\
\text { canister }\end{array}$ & $\begin{array}{l}\text { First eight worksheets of "Total } \\
2030 \text { D568-585.xls" (DOE } 2003 \\
\text { [DIRS 163377]) }\end{array}$ \\
\hline & DSNF canister count & 2,500 to 5,000 & Canisters & DOE 2004 [DIRS 169354], p. 41 \\
\hline & SRS Glass Information & Table 4-9 & $\begin{array}{l}\text { Curies/ } \\
\text { canister }\end{array}$ & Allison 2004 [DIRS 168734] \\
\hline & $\begin{array}{l}\text { Hanford estimated radiochemical } \\
\text { inventory in HLW, Basis 1/1/2030 }\end{array}$ & Table 4-10 & Curies & Hamel 2003 [DIRS 164947], Table 2 \\
\hline & $\begin{array}{l}\text { HLW canister production estimates } \\
\text { for Alt. Waste loading and canister } \\
\text { fill levels }\end{array}$ & Table 4-11 & Canisters & $\begin{array}{l}\text { Hamel } 2003 \text { [DIRS 164947], p.1-9, } \\
\text { Table 1-3 }\end{array}$ \\
\hline & $\begin{array}{l}\text { Radionuclide half-lives, constants } \\
\text { and conversion factors }\end{array}$ & $\begin{array}{l}\text { Tables } 4-3 \text { and } \\
4-13\end{array}$ & $\begin{array}{l}\text { Years, } \\
\text { grams, mass } \\
\text { per activity } \\
\left(\mathrm{m}_{\mathrm{i}} / \mathrm{a}_{\mathrm{i}}\right)\end{array}$ & Parrington et al. 1996 [DIRS 103896] \\
\hline & Half-life of ${ }^{79} \mathrm{Se}$ & Table 4-3 & Years & Singh 2002 [DIRS 164741] \\
\hline & Half-life of ${ }^{232} \mathrm{Th}$ & Table 4-3 & & $\begin{array}{l}\text { Lide } 1991 \text { [DIRS 131202], p. } 11 \text { to } \\
122\end{array}$ \\
\hline & List of Radionuclides & $\begin{array}{l}\text { Tables 4-14 } \\
\text { and 4-15 }\end{array}$ & None & $\begin{array}{l}\text { BSC 2002 [DIRS 160059], Tables } 12 \\
\text { and 13; Parrington et al. } 1996 \\
\text { [DIRS 103896] }\end{array}$ \\
\hline & Radionuclides in crud & $\begin{array}{l}\text { Appendix I.3 \& } \\
\text { I.4 }\end{array}$ & Curies & $\begin{array}{l}\text { BSC } 2004 \text { [DIRS 171407], Table } 2 \\
\text { BSC } 2004 \text { [DIRS 171435], Table } 8\end{array}$ \\
\hline & Radionuclide inventory in hardware & Table 16 & Curies & $\begin{array}{l}\text { BSC } 2004 \text { [DIRS 171435] } \\
\text { BSC } 2004 \text { [DIRS 171436] }\end{array}$ \\
\hline
\end{tabular}


Table 4-2. Waste Package Configurations and Inventory Information - Nominal Quantity for LA

\begin{tabular}{|c|c|c|c|c|}
\hline $\begin{array}{c}\begin{array}{c}\text { Configuration } \\
\text { Number }\end{array} \\
\end{array}$ & $\begin{array}{c}\text { Waste Package } \\
\text { Configuration }\end{array}$ & \begin{tabular}{|c|} 
Waste \\
Package \\
Type
\end{tabular} & $\begin{array}{c}\text { Number of Waste } \\
\text { Packages } \\
\text { (Nominal Qty. for } \\
\text { LA) }\end{array}$ & Configuration Description \\
\hline 1 & 21-PWR AP & CSNF & 4,299 & $\begin{array}{l}\text { Waste package with absorber plates for criticality control } \\
\text { that will hold up to } 21 \text { PWR assemblies }\end{array}$ \\
\hline 2 & 21-PWR CR & CSNF & 95 & $\begin{array}{l}\text { Waste packages with control rods for criticality control } \\
\text { that will hold up to } 21 \text { PWR assemblies }\end{array}$ \\
\hline 3 & 12-PWR AP long & CSNF & 163 & $\begin{array}{l}\text { Waste package with absorber plates for criticality control } \\
\text { that will hold up to } 12 \text { PWR assemblies }\end{array}$ \\
\hline 4 & 44-BWR AP & CSNF & 2,831 & $\begin{array}{l}\text { Waste package with absorber plates for criticality control } \\
\text { that will hold up to } 44 \text { BWR assemblies }\end{array}$ \\
\hline 5 & 24-BWR AP & CSNF & 84 & $\begin{array}{l}\text { Waste package with thick absorber plates for criticality } \\
\text { control that will hold up to } 24 \text { BWR assemblies }\end{array}$ \\
\hline 6 & $\begin{array}{l}5 \text { HLW short / } \\
1 \text { DSNF short }\end{array}$ & CDSP & 1,147 & $\begin{array}{l}\text { Waste package containing five short HLW glass } \\
\text { canisters and one short DSNF canister }\end{array}$ \\
\hline $7 a$ & $\begin{array}{l}5 \text { HLW long / } \\
1 \text { DSNF long }\end{array}$ & CDSP & 1,406 & $\begin{array}{l}\text { Waste package containing } 5 \text { long HLW glass canisters } \\
\text { and one long DSNF canister }\end{array}$ \\
\hline $8 a$ & $\begin{array}{l}\text { 5HLW long / } \\
1 \text { DSNF short } \\
\end{array}$ & CDSP & 31 & $\begin{array}{l}\text { Waste package containing } 5 \text { long HLW glass canisters } \\
\text { and one short DSNF canister }\end{array}$ \\
\hline $7 \mathrm{~b}$ & 5 HLW long only & CDSP & 679 & Waste package containing 5 long HLW glass canisters \\
\hline $8 b$ & $2 \mathrm{MCO} / 2 \mathrm{HLW}$ & CDSP & 149 & $\begin{array}{l}\text { Waste package containing } 2 \text { multi-canister over packs } \\
\text { and } 2 \text { long HLW glass canisters }\end{array}$ \\
\hline 9 & Naval short & Naval & 144 & \\
\hline 10 & Naval long & Naval & 156 & \\
\hline \multicolumn{3}{|l|}{ Total CDSP } & 3,412 & \\
\hline \multicolumn{3}{|c|}{ Total in CSNF + Naval } & 7,772 & \\
\hline \multicolumn{3}{|l|}{ Grand Total } & 11,184 & \\
\hline
\end{tabular}

Source: BSC 2004 [DIRS 169472], Table 11.

NOTE: The subset totals are derived from source data, but are presented here to enhance transparency of the analysis.

Table 4-3. Constants Used in Calculations

\begin{tabular}{|l|l|l|}
\hline \multicolumn{1}{|c|}{ Constant } & \multicolumn{1}{c|}{ Value } & \multicolumn{1}{c|}{ Source } \\
\hline Avogadro Number & $6.02214 \times 10^{23}$ & Parrington et al. 1996 [DIRS 103896], p. 59 \\
\hline $\mathrm{Bq} / \mathrm{Ci}$ & $3.70 \times 10^{10}$ & Parrington et al. 1996 [DIRS 103896], p. 58 \\
\hline Seconds per Mean Solar Year & $31,556,930$ & Parrington et al. 1996 [DIRS 103896], p. 55 \\
\hline Half-Lives & See Table 4-12 & Parrington et al. 1996 [DIRS 103896], pp. 18 to 50 \\
\hline Half-Life of ${ }^{79}$ Se & $2.95 \times 10^{5}$ years & Singh 2002 [DIRS 164741] \\
\hline${ }^{232} \mathrm{Th}$ & $1.40 \times 10^{10}$ & $\begin{array}{l}\text { Decimal point left out in Parrington et al. 1996 [DIRS 103896]. } \\
\text { Value confirmed by Lide 1991 [DIRS 131202], pp. 11 to 122 }\end{array}$ \\
\hline
\end{tabular}

In order to derive the radionuclide inventory for CSNF, information on assembly type, burnup, and MTU per assembly are used to develop arrival forecasts for the given repository receipt year. Table 4-4 provides the average CSNF radionuclide inventory as curies per assembly for each CSNF waste package configuration for the projected repository receipt year (year 2033). Waste package configurations 1 through 5 in Table 4-2 correspond to Bins 1 through 5 in Table 4-4. 
The data for the 32 isotopes of interest to TSPA-LA, (taken from 61 radionuclides identified for CSNF, were collected based on the 63,000-MTHM inventory. The 63,000-MTHM inventory is 90 percent of the 70,000-MTHM legislated repository "legal limit." The curies per assembly were converted to grams per assembly by multiplying by the $\mathrm{g} / \mathrm{Ci}$ for each radionuclide. The per-assembly inventories (in grams) for CSNF waste packages, multiplied by the number of assemblies per package for each configuration (e.g., 21 assemblies for configuration 1; 44 assemblies for configuration 4, etc.) shown in Table 4-2, yield the grams per package. The number of packages in each configuration shown in Table 4-2 multiplied by that configuration's per-package values yields the total grams for each waste configuration. The total number of grams for each CSNF configuration is then used to derive the weighted average. The weighted average is calculated using this grand total for the appropriate CSNF configuration divided by the total number of CSNF packages.

Table 4-4. Average Radionuclide Inventory (Curies/Assembly) for Each CSNF Waste Package Configuration at the Projected Year of Repository Emplacement (2033) for 63,000 MTU, Case A

\begin{tabular}{|c|c|c|c|c|c|}
\hline Nuclide & $\operatorname{Bin} 1^{a}$ & $\operatorname{Bin} 2^{a}$ & $\operatorname{Bin} 3^{a}$ & $\operatorname{Bin} 4^{a}$ & $\operatorname{Bin} 5^{a}$ \\
\hline${ }^{27} \mathrm{Ac}$ & 1.32E-05 & 1.19E-05 & $1.48 \mathrm{E}-05$ & $8.38 \mathrm{E}-07$ & 2.45E-07 \\
\hline${ }^{1} \mathrm{Am}$ & $1.68 \mathrm{E}+03$ & $7.64 \mathrm{E}+02$ & $2.11 \mathrm{E}+03$ & $4.39 \mathrm{E}+02$ & $7.64 \mathrm{E}+01$ \\
\hline${ }^{2 m} \mathrm{Am}$ & $4.61 \mathrm{E}+00$ & $1.02 \mathrm{E}+00$ & $6.90 \mathrm{E}+00$ & $1.43 \mathrm{E}+00$ & 7.11E-02 \\
\hline${ }^{43} \mathrm{Am}$ & $1.49 \mathrm{E}+01$ & $1.55 \mathrm{E}+00$ & $2.25 \mathrm{E}+01$ & $3.94 \mathrm{E}+00$ & $5.71 \mathrm{E}-02$ \\
\hline${ }^{37 \mathrm{~m}} \mathrm{Ba}$ & $2.70 \mathrm{E}+04$ & $7.19 \mathrm{E}+03$ & $4.34 \mathrm{E}+04$ & $8.95 \mathrm{E}+03$ & 1.07E+03 \\
\hline${ }^{14} \mathrm{C}$ & 2.91E-01 & 5.94E-01 & $3.60 \mathrm{E}-01$ & 1.42E-01 & 2.75E-02 \\
\hline${ }^{113 \mathrm{~m}} \mathrm{Cd}$ & $4.90 \mathrm{E}+00$ & 5.91E-01 & $8.86 \mathrm{E}+00$ & $1.57 \mathrm{E}+00$ & 5.92E-02 \\
\hline${ }^{36} \mathrm{Cl}$ & $5.45 \mathrm{E}-03$ & 2.16E-03 & 7.39E-03 & 2.36E-03 & 4.81E-04 \\
\hline${ }^{242} \mathrm{Cm}$ & $3.82 \mathrm{E}+00$ & 8.42E-01 & $5.69 \mathrm{E}+00$ & $1.18 \mathrm{E}+00$ & 5.87E-02 \\
\hline${ }^{243} \mathrm{~cm}$ & $6.34 \mathrm{E}+00$ & 3.51E-01 & $1.08 \mathrm{E}+01$ & $1.64 \mathrm{E}+00$ & 1.05E-02 \\
\hline${ }^{244} \mathrm{Cm}$ & $8.29 \mathrm{E}+02$ & 1.83E+01 & $1.46 \mathrm{E}+03$ & $2.07 \mathrm{E}+02$ & 2.61E-01 \\
\hline${ }^{245} \mathrm{Cm}$ & 1.99E-01 & 7.05E-03 & 3.06E-01 & 3.32E-02 & 6.10E-05 \\
\hline${ }^{246} \mathrm{Cm}$ & 6.86E-02 & 1.02E-03 & 1.04E-01 & 1.50E-02 & 3.19E-05 \\
\hline${ }^{247} \mathrm{Cm}$ & $0.00 \mathrm{E}+00$ & $0.00 \mathrm{E}+00$ & $0.00 \mathrm{E}+00$ & $0.00 \mathrm{E}+00$ & $0.00 \mathrm{E}+00$ \\
\hline${ }^{60} \mathrm{Co}$ & $2.51 \mathrm{E}+02$ & 2.37E+01 & $5.23 E+02$ & $4.30 \mathrm{E}+01$ & 7.64E-01 \\
\hline${ }^{134} \mathrm{Cs}$ & $1.82 \mathrm{E}+02$ & $5.81 \mathrm{E}+00$ & $2.63 \mathrm{E}+02$ & $6.11 \mathrm{E}+01$ & 1.08E-04 \\
\hline${ }^{135} \mathrm{Cs}$ & 2.71E-01 & 1.09E-01 & 3.86E-01 & $9.98 \mathrm{E}-02$ & 2.20E-02 \\
\hline${ }^{137} \mathrm{Cs}$ & $2.86 \mathrm{E}+04$ & $7.61 \mathrm{E}+03$ & $4.59 \mathrm{E}+04$ & $9.48 \mathrm{E}+03$ & 1.13E+03 \\
\hline${ }^{154} \mathrm{Eu}$ & $4.38 \mathrm{E}+02$ & $2.57 \mathrm{E}+01$ & $8.67 \mathrm{E}+02$ & $1.27 \mathrm{E}+02$ & $1.04 \mathrm{E}+00$ \\
\hline${ }^{155} \mathrm{Eu}$ & $4.61 \mathrm{E}+01$ & $1.96 \mathrm{E}+00$ & $9.63 \mathrm{E}+01$ & $1.79 \mathrm{E}+01$ & $2.51 \mathrm{E}-02$ \\
\hline${ }^{55} \mathrm{Fe}$ & $8.49 \mathrm{E}+00$ & 6.94E-01 & $1.52 \mathrm{E}+01$ & $3.87 \mathrm{E}+00$ & 2.31E-03 \\
\hline${ }^{221} \mathrm{Fr}^{\mathrm{a}}$ & $0.00 \mathrm{E}+00$ & $0.00 \mathrm{E}+00$ & $0.00 \mathrm{E}+00$ & $0.00 \mathrm{E}+00$ & $0.00 \mathrm{E}+00$ \\
\hline${ }^{3} \mathrm{H}$ & $7.47 \mathrm{E}+01$ & $1.28 \mathrm{E}+01$ & 1.37E+02 & $2.68 \mathrm{E}+01$ & $1.58 \mathrm{E}+00$ \\
\hline 129 & 1.71E-02 & 6.62E-03 & \begin{tabular}{|l|}
$2.39 \mathrm{E}-02$ \\
\end{tabular} & $5.60 \mathrm{E}-03$ & 1.10E-03 \\
\hline${ }^{85} \mathrm{Kr}$ & $7.50 \mathrm{E}+02$ & $1.17 \mathrm{E}+02$ & $1.41 \mathrm{E}+03$ & $2.54 \mathrm{E}+02$ & $1.15 \mathrm{E}+01$ \\
\hline${ }^{93 \mathrm{~m}} \mathrm{Nb}$ & $8.61 \mathrm{E}+00$ & $1.70 \mathrm{E}+00$ & $1.49 \mathrm{E}+01$ & 3.49E-01 & 2.28E-01 \\
\hline${ }^{94} \mathrm{Nb}$ & 6.60E-01 & 2.63E-01 & $9.15 \mathrm{E}-01$ & 1.46E-02 & 4.25E-02 \\
\hline${ }^{59} \mathrm{Ni}$ & $1.75 \mathrm{E}+00$ & $1.81 \mathrm{E}+00$ & $2.28 \mathrm{E}+00$ & 4.07E-01 & 2.19E-01 \\
\hline
\end{tabular}


Table 4-4. Average Radionuclide Inventory (Curies/Assembly) for Each CSNF Waste Package Configuration at the Projected Year of Repository Emplacement (2033) for 63,000 MTU, Case A (Continued)

\begin{tabular}{|c|c|c|c|c|c|}
\hline Nuclide & $\operatorname{Bin} 1^{a}$ & $\operatorname{Bin} 2^{a}$ & $\operatorname{Bin} 3^{a}$ & $\operatorname{Bin} 4^{a}$ & $\operatorname{Bin} 5^{a}$ \\
\hline${ }^{3} \mathrm{Ni}$ & $1.97 \mathrm{E}+02$ & $1.66 \mathrm{E}+02$ & $2.74 \mathrm{E}+02$ & $4.55 \mathrm{E}+01$ & $1.92 \mathrm{E}+01$ \\
\hline $\mathrm{Np}$ & 1.93E-01 & 7.02E-02 & 2.69E-01 & 5.05E-02 & $8.15 \mathrm{E}-03$ \\
\hline $\mathrm{Pa}$ & $2.48 \mathrm{E}-05$ & $2.16 \mathrm{E}-05$ & 3.34E-05 & 7.33E-06 & $5.23 \mathrm{E}-06$ \\
\hline $\mathrm{Pb}^{\mathrm{a}}$ & $0.00 \mathrm{E}+00$ & $0.00 \mathrm{E}+00$ & $0.00 \mathrm{E}+00$ & $0.00 \mathrm{E}+00$ & $0.00 \mathrm{E}+00$ \\
\hline $\mathrm{Pd}$ & 6.34E-02 & 1.82E-02 & $9.00 \mathrm{E}-02$ & 2.02E-02 & 2.32E-03 \\
\hline $\mathrm{Pm}$ & 3.37E+02 & $4.70 \mathrm{E}+01$ & $6.10 \mathrm{E}+02$ & $1.52 \mathrm{E}+02$ & 1.31E-02 \\
\hline${ }^{8} \mathrm{Po}^{\mathrm{a}}$ & $0.00 \mathrm{E}+00$ & $0.00 \mathrm{E}+00$ & $0.00 \mathrm{E}+00$ & $0.00 \mathrm{E}+00$ & $0.00 \mathrm{E}+00$ \\
\hline $\mathrm{Pu}$ & $1.57 \mathrm{E}+03$ & $2.25 \mathrm{E}+02$ & $2.42 E+03$ & $4.04 \mathrm{E}+02$ & $1.33 \mathrm{E}+01$ \\
\hline $\mathrm{Pu}$ & $1.55 \mathrm{E}+02$ & $1.13 \mathrm{E}+02$ & $2.02 E+02$ & $4.49 \mathrm{E}+01$ & $2.55 \mathrm{E}+01$ \\
\hline $\mathrm{Pu}$ & $2.57 \mathrm{E}+02$ & $1.07 \mathrm{E}+02$ & $3.48 \mathrm{E}+02$ & $8.92 \mathrm{E}+01$ & $1.67 \mathrm{E}+01$ \\
\hline $\mathrm{Pu}$ & $1.61 \mathrm{E}+04$ & $2.66 \mathrm{E}+03$ & $2.89 E+04$ & $4.43 \mathrm{E}+03$ & $1.88 \mathrm{E}+02$ \\
\hline${ }^{2} \mathrm{Pu}$ & $1.18 \mathrm{E}+00$ & 2.12E-01 & $1.71 \mathrm{E}+00$ & 3.77E-01 & 1.26E-02 \\
\hline${ }^{6} \mathrm{Ra}^{\mathrm{a}}$ & $0.00 \mathrm{E}+00$ & $0.00 \mathrm{E}+00$ & $0.00 \mathrm{E}+00$ & $0.00 \mathrm{E}+00$ & $0.00 \mathrm{E}+00$ \\
\hline${ }^{8} \mathrm{Ra}^{\mathrm{a}}$ & $0.00 \mathrm{E}+00$ & $0.00 \mathrm{E}+00$ & $0.00 \mathrm{E}+00$ & $0.00 \mathrm{E}+00$ & $0.00 \mathrm{E}+00$ \\
\hline $\mathrm{Ru}$ & $2.76 \mathrm{E}+01$ & 2.69E-01 & $8.92 \mathrm{E}+00$ & $6.92 \mathrm{E}+00$ & 3.22E-10 \\
\hline $5 \mathrm{Sb}$ & $2.35 \mathrm{E}+01$ & $1.74 \mathrm{E}+00$ & $4.36 \mathrm{E}+01$ & $9.68 \mathrm{E}+00$ & $6.55 \mathrm{E}-04$ \\
\hline${ }^{79} \mathrm{Se}$ & $3.59 \mathrm{E}-02$ & 1.48E-02 & 5.02E-02 & 1.19E-02 & $2.60 \mathrm{E}-03$ \\
\hline${ }^{147} \mathrm{Sm}^{\mathrm{a}}$ & $0.00 \mathrm{E}+00$ & $0.00 \mathrm{E}+00$ & $0.00 \mathrm{E}+00$ & $0.00 \mathrm{E}+00$ & $0.00 \mathrm{E}+00$ \\
\hline${ }^{51} \mathrm{Sm}$ & $1.66 \mathrm{E}+02$ & $9.05 \mathrm{E}+01$ & $2.38 \mathrm{E}+02$ & $4.04 \mathrm{E}+01$ & $1.80 \mathrm{E}+01$ \\
\hline $\mathrm{Sn}$ & 2.96E-01 & $9.96 \mathrm{E}-02$ & 4.16E-01 & $9.66 \mathrm{E}-02$ & 1.48E-02 \\
\hline${ }^{0} \mathrm{Sr}$ & $1.91 \mathrm{E}+04$ & $5.61 \mathrm{E}+03$ & $3.07 \mathrm{E}+04$ & $6.41 \mathrm{E}+03$ & $8.79 \mathrm{E}+02$ \\
\hline${ }^{99} \mathrm{Tc}$ & $7.12 \mathrm{E}+00$ & $3.09 \mathrm{E}+00$ & $9.89 \mathrm{E}+00$ & $2.40 \mathrm{E}+00$ & 5.58E-01 \\
\hline${ }^{229} \mathrm{Th}^{\mathrm{a}}$ & $0.00 \mathrm{E}+00$ & $0.00 \mathrm{E}+00$ & $0.00 \mathrm{E}+00$ & $0.00 \mathrm{E}+00$ & $0.00 \mathrm{E}+00$ \\
\hline${ }^{0} \mathrm{Th}$ & 1.70E-04 & 2.52E-04 & 1.71E-04 & 5.94E-05 & 1.04E-04 \\
\hline${ }^{232} \mathrm{Th}^{\mathrm{a}}$ & $0.00 \mathrm{E}+00$ & $0.00 \mathrm{E}+00$ & $0.00 \mathrm{E}+00$ & $0.00 \mathrm{E}+00$ & $0.00 \mathrm{E}+00$ \\
\hline${ }^{232} \mathrm{U}$ & 1.39E-02 & $1.78 \mathrm{E}-03$ & $2.17 \mathrm{E}-02$ & 3.19E-03 & 1.11E-04 \\
\hline $2{ }^{233} \mathrm{U}$ & 3.71E-05 & 2.12E-05 & 4.45E-05 & 5.77E-06 & $4.08 \mathrm{E}-07$ \\
\hline${ }^{234} \mathrm{U}$ & $6.03 \mathrm{E}-01$ & 5.54E-01 & 7.73E-01 & $1.98 \mathrm{E}-01$ & 1.94E-01 \\
\hline${ }^{235} \mathrm{U}$ & $7.53 \mathrm{E}-03$ & 1.42E-02 & $9.12 \mathrm{E}-03$ & $2.29 \mathrm{E}-03$ & $6.18 \mathrm{E}-03$ \\
\hline${ }^{236} \mathrm{U}$ & 1.39E-01 & 7.58E-02 & 1.92E-01 & 4.58E-02 & 1.52E-02 \\
\hline $238 \mathrm{U}$ & 1.35E-01 & 1.18E-01 & $1.68 \mathrm{E}-01$ & 5.64E-02 & 5.43E-02 \\
\hline${ }^{90} Y$ & $1.91 \mathrm{E}+04$ & $5.61 \mathrm{E}+03$ & $3.07 E+04$ & $6.41 \mathrm{E}+03$ & $8.79 \mathrm{E}+02$ \\
\hline $\mathrm{Zr}$ & 7.05E-01 & 2.91E-01 & 9.83E-01 & 2.55E-01 & 5.68E-02 \\
\hline
\end{tabular}

Source: CRWMS M\&O 2000 [DIRS 138239]. See Appendix III this document, file inv_rev1.xls, worksheet a63 for data.

NOTE: ${ }^{\mathrm{a}} 0.00 \mathrm{E}+00$ is the value presented in the data input source. Bin numbers ( 1 to 5 ) are equivalent to Configuration numbers (1-5) in Table 4-2.

To estimate uncertainty in the weighted average inventory for CSNF, the burnups of the radionuclides were examined. Table 4-5 and Table 4-6 present burnup characteristics for assembly types corresponding to the CSNF waste package configurations identified in Table 4-2. Cases A to $\mathrm{C}$ in Table 4-5 are based on 1999 waste stream cases (CRWMS M\&O 2000 
[DIRS 138239]). Table 4-6, Cases A' to D' (BSC 2003 [DIRS 165990]) are based on four 2002 waste stream cases. These "cases" represent different arrival "case" methodologies pertaining to forecasts on how waste packages will arrive at the repository (in terms of age of assembly at the time of arrival) and, therefore, affect the characterization of the inventory. The cases are further discussed in Section 6; however, it is noted here that the CSNF radionuclide inventory presented in Table 4-4 is based on the "Case A 63,000 MTU" scenario of CSNF for the 1999 forecast waste streams (CRWMS M\&O 2000 [DIRS 138239]). The weighted average burnups were calculated using the three 1999 waste stream cases (A to C), and the four 2002 waste stream cases (A' to $\left.\mathrm{D}^{\prime}\right)$. These values were then compared to the nominal base case (Case A) in order to evaluate uncertainty associated with the inventory. The data are presented in Section 6.6.1; the calculations are documented in Appendix II and Appendix III CD files $(687 \mathrm{~kb}$ workbook: inv_rev1.xls). The description of these files and the flow of data files or information are presented in Appendix II.

Table 4-5. 63,000 MTU Waste Package Burnup Characteristics Based on 1999 CSNF Waste Streams

\begin{tabular}{|c|c|c|c|}
\hline Case & $\begin{array}{c}63,000 \text { MTU } \\
\text { Waste Package }\end{array}$ & $\begin{array}{c}\text { Number of } \\
\text { Packages }\end{array}$ & $\begin{array}{c}\text { Average Initial } \\
\text { Burnup (GWd/MTU) }\end{array}$ \\
\hline \multirow{5}{*}{ A } & 21-PWR AP & 4,299 & 41.485 \\
\hline & 21-PWR CR & 95 & 19.624 \\
\hline & 12-PWR AP & 163 & 46.326 \\
\hline & 44-BWR & 2,831 & 34.08 \\
\hline & 24-BWR & 84 & 8.065 \\
\hline \multirow{5}{*}{ B } & 21-PWR AP & 4,301 & 42.887 \\
\hline & 21-PWR CR & 93 & 19.544 \\
\hline & 12-PWR AP & 163 & 48.302 \\
\hline & 44-BWR & 2,836 & 35.279 \\
\hline & 24-BWR & 84 & 8.042 \\
\hline \multirow{5}{*}{ C } & 21-PWR AP & 4,298 & 40.536 \\
\hline & 21-PWR CR & 101 & 19.547 \\
\hline & 12-PWR AP & 163 & 39.67 \\
\hline & 44-BWR & 2,808 & 32.448 \\
\hline & 24-BWR & 97 & 8.466 \\
\hline
\end{tabular}

Source: CRWMS 2000 [DIRS 138239], Tables 10, 12, and 14.

Table 4-6. CSNF Assembly Totals and Burnup Characteristics for the 63,000 MTHM Cases Based on 2002 CSNF Waste Streams

\begin{tabular}{|c|c|c|c|c|}
\hline & \multicolumn{2}{|c|}{$\begin{array}{c}\text { Average Burnup } \\
\text { (GWd/MTH) }\end{array}$} & \multicolumn{2}{c|}{ Number of Assemblies } \\
\hline Case & BWR & PWR & BWR & PWR \\
\hline A' $^{\prime}$ & 32 & 39 & 124,848 & 94,344 \\
\hline B' $^{\prime}$ & 42 & 46 & 127,303 & 94,373 \\
\hline C' $^{\prime}$ & 45 & 49 & 127,700 & 94,405 \\
\hline D' $^{\prime}$ & 47 & 51 & 127,772 & 93,252 \\
\hline
\end{tabular}

Source: BSC 2003 [DIRS 165990], Tables 2 and 4. 
The uncertainty associated with CSNF inventory projections includes the uncertainty related to measured versus calculated burn-up for BWR and PWR fuel assemblies (Massie 2004 [DIRS 170651], Summary Sheet) and the manner in which this affects the radionuclide inventory.

Equation 4-1 evaluates the percent difference of calculated to measured burnup $(P)$ :

$$
P=100 \text { (calculated burnup - measured burnup)/(measured burnup) }
$$

Table 4-7 presents additional data used to evaluate inventory projections. These data pertain to biases and uncertainties between calculated and measured isotopic concentrations. These data are used in Sec. 6.6.1 to develop the uncertainty in isotopic predictions.

Table 4-7. Summary of Percent Differences Between Calculated and Computed Compositions

\begin{tabular}{|c|c|c|c|c|c|}
\hline \multicolumn{3}{|c|}{ PWR $^{\text {a }}$} & \multicolumn{3}{|c|}{ BWR $^{b}$} \\
\hline Isotope $^{c}$ & Element & Ave. $(\%)^{d}$ & Isotope $^{c}$ & Element & Ave. $(\%)^{d}$ \\
\hline \multirow[t]{2}{*}{243} & $\mathrm{Am}$ & -4.3 & 241 & $\mathrm{Am}$ & 4.1 \\
\hline & & & 135 & Cs & 5.1 \\
\hline 137 & Cs & 1.3 & 137 & Cs & 1.5 \\
\hline 238 & $\mathrm{Pu}$ & 2.6 & 238 & $\mathrm{Pu}$ & -7 \\
\hline 239 & $\mathrm{Pu}$ & -2.1 & 239 & $\mathrm{Pu}$ & -2.1 \\
\hline 240 & $\mathrm{Pu}$ & -0.2 & 240 & $\mathrm{Pu}$ & -0.9 \\
\hline 241 & $\mathrm{Pu}$ & -1 & 241 & $\mathrm{Pu}$ & -4.5 \\
\hline \multirow[t]{3}{*}{242} & $\mathrm{Pu}$ & 3.1 & 242 & $\mathrm{Pu}$ & 0.5 \\
\hline & & & 90 & $\mathrm{Sr}$ & 8.9 \\
\hline & & & 99 & $\mathrm{Tc}$ & 12.1 \\
\hline 234 & $U$ & 6.1 & 234 & $U$ & -0.2 \\
\hline 235 & U & 0.1 & 235 & U & -2 \\
\hline 236 & $U$ & -2.8 & 236 & $U$ & -1.2 \\
\hline 238 & $U$ & 0.1 & 238 & $U$ & -0.1 \\
\hline $\begin{array}{ll}\text { NOTES: } & \text { a } \\
& \mathrm{b} \\
& \mathrm{c} \\
& \mathrm{d}\end{array}$ & \multicolumn{5}{|c|}{$\begin{array}{l}\text { DeHart and Hermann } 1996 \text { [DIRS 156084], Table } 19 \\
\text { Hermann and DeHart } 1998 \text { [DIRS 106563], Table } 24 \\
\text { Only isotopes important to TSPA-LA see Section } 6.1 \\
\text { (Calculated/measured }-1 \text { ) } \times 100 \% \text {, average of } 4 \text { to } 30 \text { samples. } \\
\text { This value is dependent on the cross section and fission yield } \\
\text { libraries used. These values were calculated using the } \\
\text { 44GROUPNDF5 cross-section and fission yield libraries. }\end{array}$} \\
\hline
\end{tabular}

Table 4-8 provides the summary of curies for the 32 radionuclides of interest for DSNF (DOE 2003 [DIRS 163377] Section 8). Similar to the mathematical operations described for the CSNF data, the DSNF inventory (in curies) for the radionuclides of interest is converted to grams for the nominal and bounding fuel inventories for each canister or assembly type. The total grams of each radionuclide for the total number of canisters or assemblies that comprise DSNF is then derived. These data are also used to develop a "base case" for DSNF that contains all wastes except the bare assemblies (see DSNF assumptions in Sec. 5.2). The uncertainty is computed from the ratio of the maximum to the nominal value for each isotope. Analyses of the data are presented in Section 6.6.2 and Appendices II and III. The description of the calculations, a list of the files containing data calculated, and an illustration of the flow of data 
and calculations are presented in Appendix II. The data corresponding to these files and calculations are documented on Excel worksheets in the Appendix III CD file inv_rev1.xls (687kb workbook: inv_rev1.xls). The data in Table 4-8 are used to develop the new codisposal configurations to accommodate DSNF shown in Table 6-3.

Tables 4-10 and 4-11 provide the basis for the radionuclide content of the HLW glass for the license application. The curie content at the decay date of 2030 is used to perform the mathematical conversions similar to those described for CSNF and DSNF. The radionuclide inventory for the various batches in Table 4-9 is used to develop curves that show the heterogeneity of this DSNF inventory. Analysis of these data is presented in Sections 6.4 and 6.6.3. The description of calculations, a list of the data files used in calculations, and a schematic illustrating the flow of calculations and data files is presented in Appendix II. The data contained in these files for calculations and the results are documented in Appendix III CD files (534kb workbook: inv_rev1.xls).

Table 4-10 provides the summary of the estimated HLW inventory for canisters at the Hanford site as of January 1, 2001 for the radionuclides of interest decayed to January 1, 2030. Although ${ }^{137} \mathrm{Cs}$ and ${ }^{90} \mathrm{Sr}$ capsules are not called out in the new data for Hanford, their new values bound the old values reported in Source Terms for HLW Glass (CRWMS M\&O 2000 [DIRS 151947]. These values are compared and plotted in inv_rev1.xls, worksheet newHLW. Table 4-11 provides the HLW canister production estimates for three production cases (program, planning, and technology) applied to three alternative canister-fill scenarios. The analysis of these data result in values that bound the expected range of HLW canisters to be produced at Hanford's Waste Treatment and Immobilization Plant. The data are used to calculate the inventory in grams and curies for the radionuclides important to dose at the time of expected emplacement. These data are provided so that emplacement of waste in the repository can be planned in light of the various waste package configurations designed for the various kinds of nuclear wastes.

Table 4-11 provides a matrix for the number of canisters possible when three radionuclide loadings and three canister-filling cases are considered. Uncertainty factors for the HLW radionuclide inventory are developed from these data (Tables 4-9, 4-10, and 4-11) and a discussion can be found in Section 6.6.3.

Table 4-12 provides the half-lives for the 32 radionuclides of interest for TSPA-LA. The isotopic composition of the inventory is a key factor in the design, licensing and operation of the repository (and related systems). Since this inventory is time dependent, radionuclide half-lives are used to evaluate and determine this inventory at the time of emplacement. 


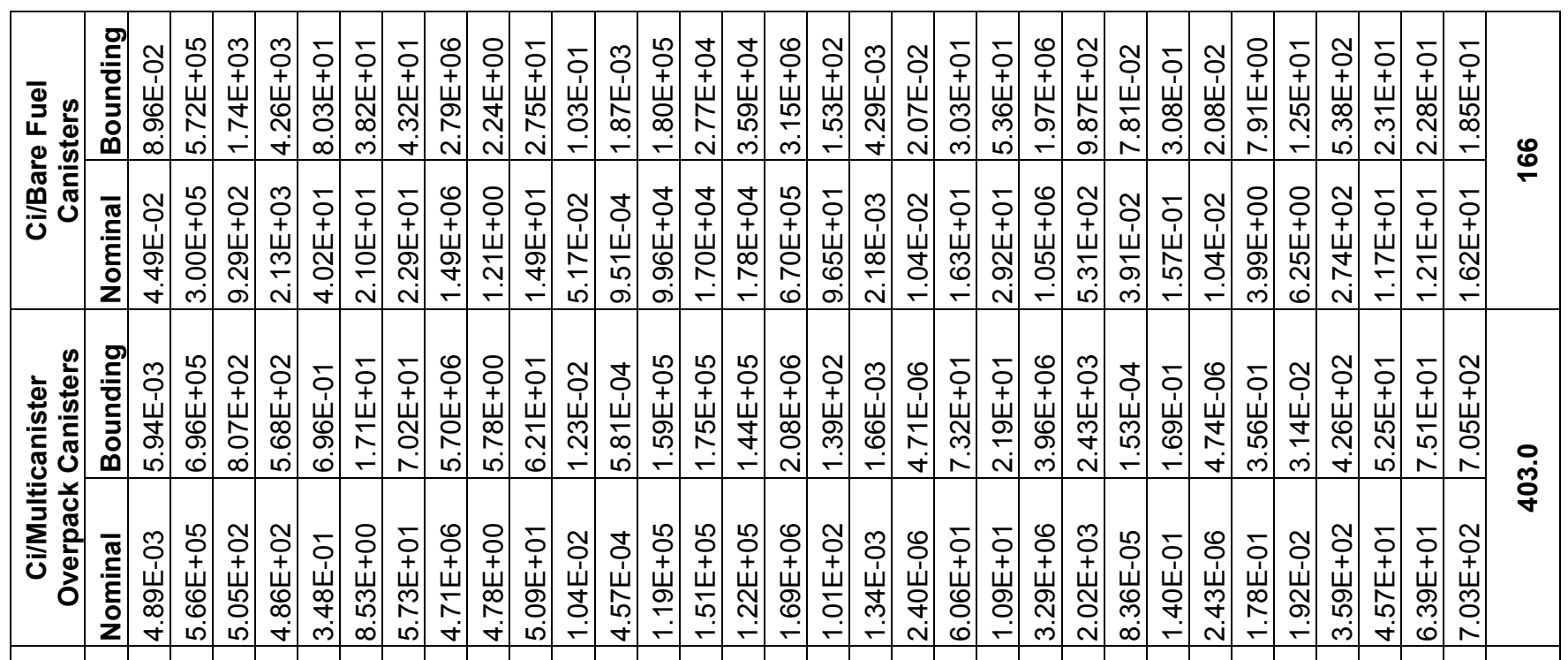

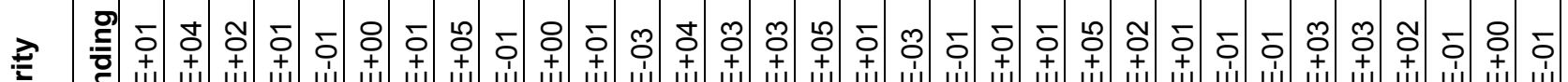

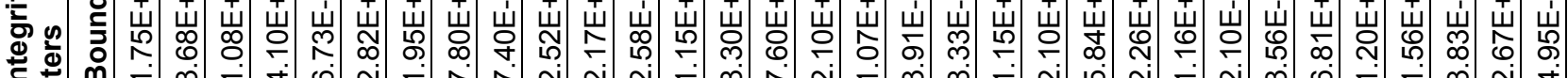

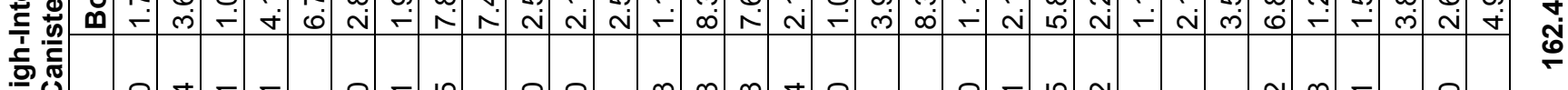

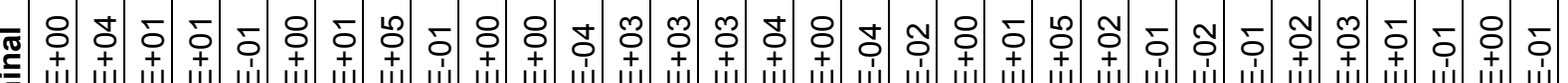

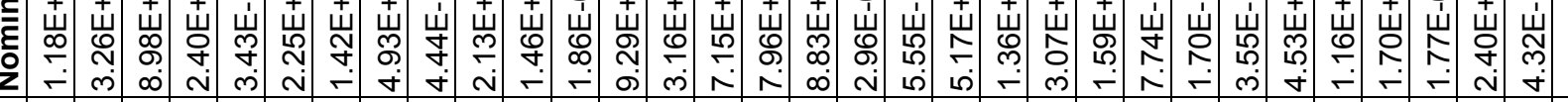

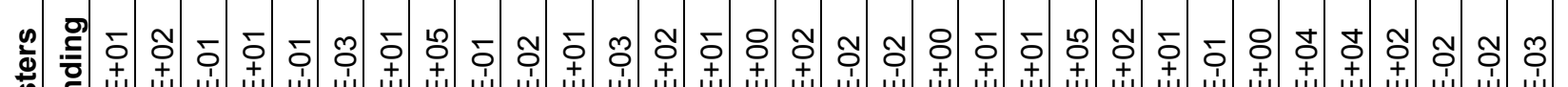

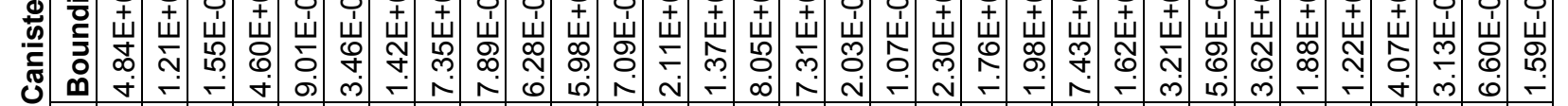
in

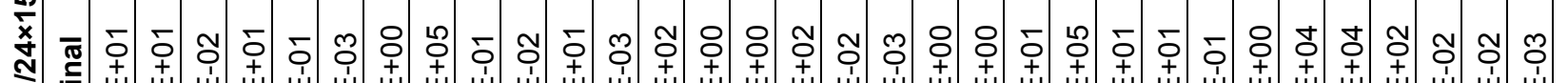

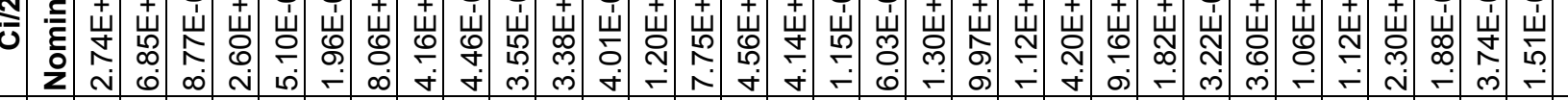

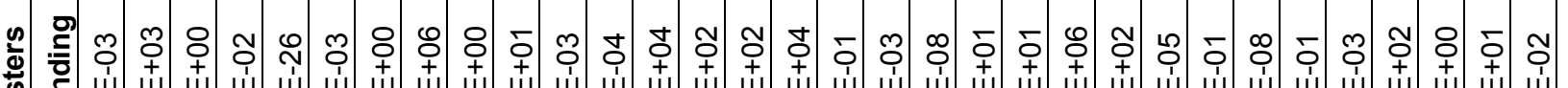

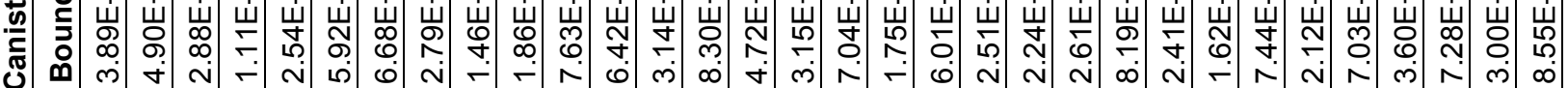

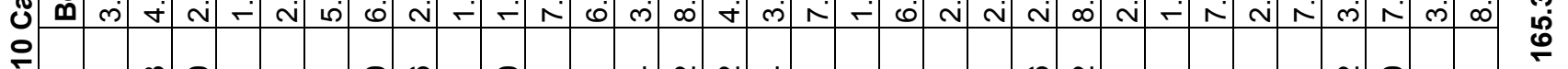

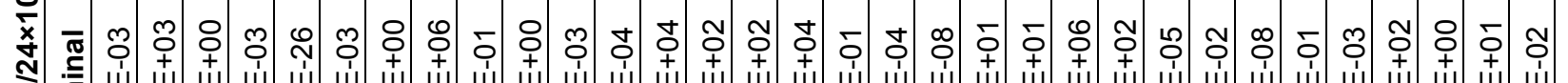

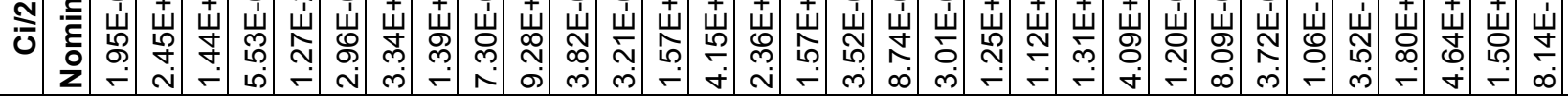

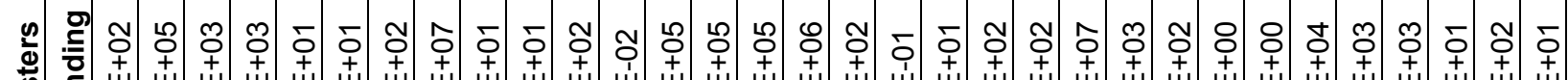

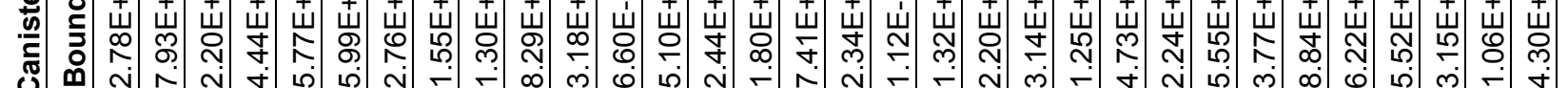
只

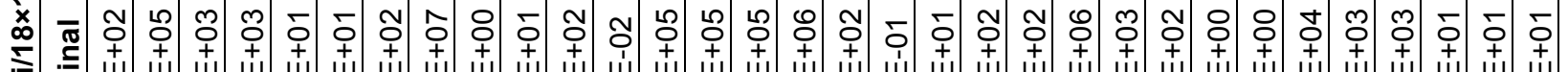

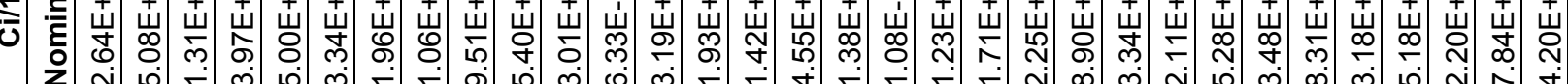

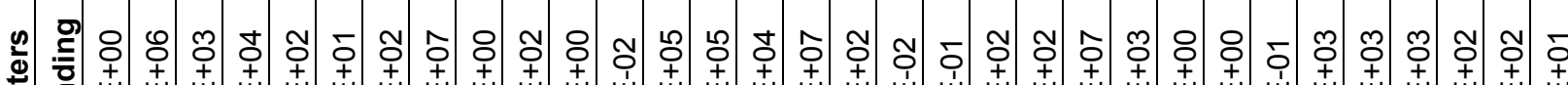
它悹

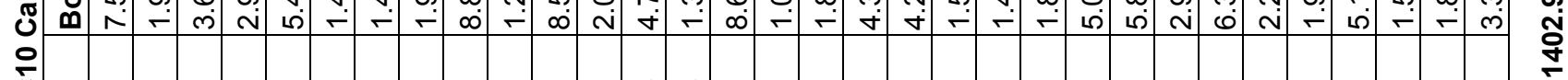

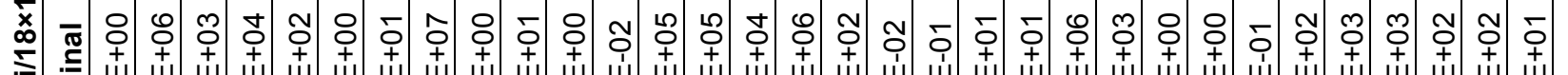

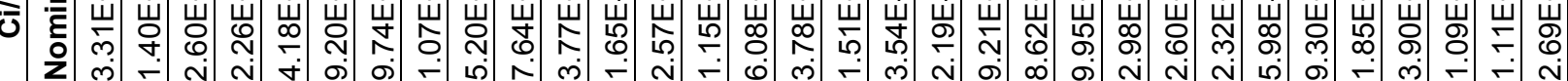

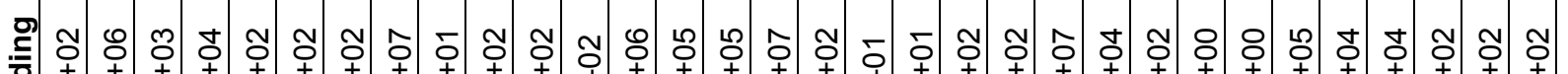

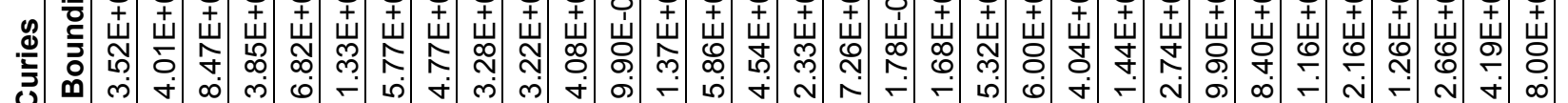

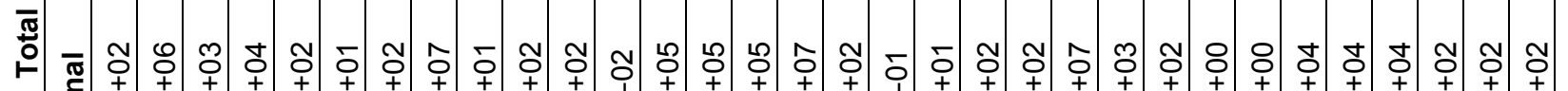

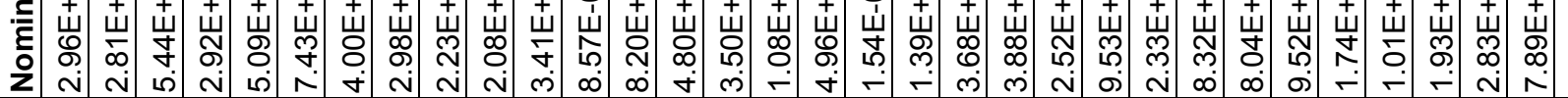


Table 4-9. New Estimated Curies Per Canister for Savannah River Site (SRS) HLW (Batches 1A, 1B, 2 and 3 , and 4 to 10 )

\begin{tabular}{|c|c|c|c|c|}
\hline \multirow[b]{2}{*}{ Radionuclide } & \multicolumn{4}{|c|}{ Batch (Curies) } \\
\hline & $1 A^{a}$ & $1 B^{b}$ & 2 and $3^{c}$ & 4 to $10^{d}$ \\
\hline${ }^{227} \mathrm{Ac}$ & 6.4196E-08 & 4.6920E-08 & 8.5283E-08 & 6.8448E-08 \\
\hline${ }^{241} \mathrm{Am}$ & $4.1273 E+00$ & $4.5983 E+00$ & $2.2002 \mathrm{E}+01$ & $7.1435 \mathrm{E}+01$ \\
\hline${ }^{243} \mathrm{Am}$ & 2.3323E-02 & 3.5501E-02 & 3.6707E-01 & 4.2980E-09 \\
\hline${ }^{14} \mathrm{C}$ & - & - & - & - \\
\hline${ }^{36} \mathrm{Cl}$ & - & - & - & - \\
\hline${ }^{245} \mathrm{Cm}$ & 3.4999E-04 & - & 2.6618E-03 & 6.1466E-03 \\
\hline${ }^{135} \mathrm{Cs}$ & $3.2400 \mathrm{E}-04$ & 5.1600E-04 & 7.4399E-04 & 1.2400E-01 \\
\hline${ }^{137} \mathrm{Cs}$ & $1.7272 \mathrm{E}+01$ & $4.5063 E+01$ & $1.0212 \mathrm{E}+02$ & $1.7020 \mathrm{E}+04$ \\
\hline${ }^{129} \mathrm{I}$ & - & 7.2900 E-05 & 5.2200E-06 & - \\
\hline${ }^{237} \mathrm{~Np}$ & 8.6761E-03 & 1.0542E-02 & 9.3651E-03 & 2.1704E-02 \\
\hline${ }^{231} \mathrm{~Pa}$ & 1.6097E-07 & 1.3325E-07 & $2.5896 \mathrm{E}-07$ & 2.0920E-07 \\
\hline${ }^{210} \mathrm{~Pb}$ & 1.1539E-08 & $4.4721 \mathrm{E}-08$ & 8.1881E-09 & 7.7802E-09 \\
\hline${ }^{238} \mathrm{Pu}$ & $2.7255 \mathrm{E}+01$ & $4.6471 \mathrm{E}+01$ & $2.1417 \mathrm{E}+01$ & $5.4948 E+02$ \\
\hline${ }^{239} \mathrm{Pu}$ & $4.1858 \mathrm{E}+00$ & $3.3772 \mathrm{E}+00$ & $5.2864 \mathrm{E}+00$ & $1.1291 \mathrm{E}+01$ \\
\hline${ }^{240} \mathrm{Pu}$ & $1.1210 \mathrm{E}+00$ & 1.1747E+00 & $1.6894 \mathrm{E}+00$ & $5.3319 \mathrm{E}+00$ \\
\hline${ }^{241} \mathrm{Pu}$ & $3.6146 \mathrm{E}+00$ & $6.8403 \mathrm{E}+00$ & $5.2572 \mathrm{E}+00$ & $9.6093 \mathrm{E}+01$ \\
\hline${ }^{242} \mathrm{Pu}$ & $9.8616 \mathrm{E}-04$ & 1.9614E-03 & 3.1613E-03 & 1.1502E-02 \\
\hline${ }^{226} \mathrm{Ra}$ & 4.1214E-08 & 1.4139E-07 & 3.5806E-08 & 3.8956E-08 \\
\hline${ }^{228} \mathrm{Ra}$ & $6.9194 \mathrm{E}-13$ & 1.1175E-04 & $2.4904 \mathrm{E}-05$ & 9.0666E-04 \\
\hline${ }^{79} \mathrm{Se}$ & 6.7775E-03 & 5.8681E-02 & 4.3088E-02 & - \\
\hline${ }^{126} \mathrm{Sn}$ & 4.0090E-03 & 2.3095E-02 & 3.0894E-02 & - \\
\hline${ }^{90} \mathrm{Sr}$ & $1.6010 \mathrm{E}+02$ & $1.2159 \mathrm{E}+03$ & $1.6155 \mathrm{E}+03$ & $1.4104 \mathrm{E}+04$ \\
\hline${ }^{99} \mathrm{Tc}$ & 1.3598E-01 & 1.2399E-01 & 8.6792E-02 & $7.8193 E+00$ \\
\hline${ }^{229} \mathrm{Th}$ & 1.3297E-04 & 1.7108E-04 & 1.8785E-05 & 8.3143E-05 \\
\hline${ }^{230} \mathrm{Th}$ & 5.5935E-06 & $1.4574 \mathrm{E}-05$ & 6.2142E-06 & 8.6012E-06 \\
\hline${ }^{232} \mathrm{Th}$ & $9.0127 \mathrm{E}-13$ & 1.1500E-04 & $2.5900 \mathrm{E}-05$ & 9.4400E-04 \\
\hline${ }^{232} \mathrm{U}$ & - & - & - & 1.2826E-04 \\
\hline${ }^{233} \mathrm{U}$ & 1.5999E-02 & 3.0197E-02 & 7.3702E-03 & 3.2899E-02 \\
\hline${ }^{234} U$ & 1.9137E-02 & 2.7487E-02 & 2.6428E-02 & 5.8085E-02 \\
\hline${ }^{235} \mathrm{U}$ & 2.1615E-04 & 2.1310 E-04 & 4.5314E-04 & 3.6930E-04 \\
\hline${ }^{236} \mathrm{U}$ & 5.1916E-04 & 7.3003E-04 & 6.5233E-04 & 1.5442E-03 \\
\hline${ }^{238} \mathrm{U}$ & 6.7800E-03 & 5.3300E-03 & 1.7400E-02 & 1.6500E-02 \\
\hline Total Canisters & 495 & 726 & 705 & 3,134 \\
\hline
\end{tabular}

Source: $\quad{ }^{a}$ Allison 2004 [DIRS 168734], Appendix 1 (i.e., Fowler report), Table 5.

${ }^{\mathrm{b}}$ Allison 2004 [DIRS 168734], Appendix 1 (i.e., Fowler report), Table 6.

${ }^{\mathrm{c}}$ Allison 2004 [DIRS 168734], Appendix 1 (i.e., Fowler report), Table 7.

dAllison 2004 [DIRS 168734], Appendix 1 (i.e., Fowler report), Table 8. 
Table 4-10. Estimated Radioactivity in the Hanford HLW Canisters at Decay Date of 2030

\begin{tabular}{|c|c|c|c|c|c|}
\hline Isotope & Element & $\begin{array}{c}\text { Estimated } \\
\text { Radiochemical } \\
\text { Inventory in HLW } \\
\text { Canisters, Basis } \\
\text { January 1, 2030 } \\
\text { (Curies) } \\
\end{array}$ & Isotope & Element & $\begin{array}{c}\text { Estimated } \\
\text { Radiochemical } \\
\text { Inventory in HLW } \\
\text { Canisters, Basis } \\
\text { January 1, 2030 } \\
\text { (Curies) } \\
\end{array}$ \\
\hline 227 & $A c$ & 52 & 240 & $\mathrm{Pu}$ & 12,262 \\
\hline 241 & $\mathrm{Am}$ & 138,408 & 241 & $\mathrm{Pu}$ & 30,931 \\
\hline 243 & $\mathrm{Am}$ & 15 & 242 & $\mathrm{Pu}$ & 1 \\
\hline 242 & $\mathrm{Cm}$ & 0 & 226 & $\mathrm{Ra}$ & 0.09 \\
\hline 243 & $\mathrm{Cm}$ & 7 & 228 & $\mathrm{Ra}$ & 2 \\
\hline 244 & $\mathrm{Cm}$ & 98 & 106 & $\mathrm{Ru}$ & 0 \\
\hline 60 & Co & 179 & 125 & $\mathrm{Sb}$ & 15 \\
\hline 134 & Cs & 1 & 79 & $\mathrm{Se}$ & 122 \\
\hline 137 & Cs & $23,464,803$ & 151 & $\mathrm{Sm}$ & $2,797,968$ \\
\hline 152 & $\mathrm{Eu}$ & 369 & 126 & Sn & 579 \\
\hline 154 & $\mathrm{Eu}$ & 28,084 & 90 & $\mathrm{Sr}$ & $25,114,788$ \\
\hline 155 & $\mathrm{Eu}$ & 1 & 99 & Tc & 29,697 \\
\hline 129 & 1 & 48 & 229 & Th & 2 \\
\hline 137 & $\mathrm{mBa}^{\mathrm{a}}$ & $23,464,803$ & 232 & Th & 8 \\
\hline 113 & $\mathrm{mCd}^{\mathrm{a}}$ & 3,867 & 232 & $U$ & 33 \\
\hline 93 & $\mathrm{mNb}^{\mathrm{a}}$ & 1,138 & 233 & U & 510 \\
\hline 59 & $\mathrm{Ni}$ & 1,370 & 234 & U & 220 \\
\hline 63 & $\mathrm{Ni}$ & 104,703 & 235 & $U$ & 9 \\
\hline 237 & $\mathrm{~Np}$ & 141 & 236 & U & 6 \\
\hline 231 & $\mathrm{~Pa}$ & 272 & 238 & $U$ & 199 \\
\hline 238 & $\mathrm{Pu}$ & 3,880 & 90 & $\mathrm{Y}$ & $25,114,788$ \\
\hline 239 & $\mathrm{Pu}$ & 69,042 & 93 & $\mathrm{Zr}$ & 4,810 \\
\hline
\end{tabular}

Source: Hamel 2003 [DIRS 164947], Table 2.

a The "m" stands for metastable and is in the source table as shown.

Table 4-11. Hanford HLW Canister Production Estimates for Alternative Canister Wastes Loading and Canister Fill Levels

\begin{tabular}{|c|c|c|c|c|c|}
\hline \multirow{2}{*}{$\begin{array}{c}\text { Canister Fill } \\
\text { Scenario }\end{array}$} & \multirow{2}{*}{$\begin{array}{c}\text { Canister } \\
\text { (percent fill) }\end{array}$} & \multirow{2}{*}{$\begin{array}{c}\text { Canister Glass } \\
\text { Volume }\left(\mathrm{m}^{3}\right)\end{array}$} & $\begin{array}{c}\text { Program Case } \\
\text { (assumes } \\
27.7 \text { wt \% waste } \\
\text { loading) }\end{array}$ & $\begin{array}{c}\text { Planning Case } \\
\text { (assumes } \\
36.3 \text { wt } \% \text { waste } \\
\text { loading) }\end{array}$ & $\begin{array}{c}\text { Technology Case } \\
\text { (assumes } \\
45 \text { wt \% waste } \\
\text { loading) }\end{array}$ \\
\hline & & & \multicolumn{3}{|c|}{ Canisters } \\
\hline Maximum & 100 & 1.19 & 11,484 & 8,744 & 7,071 \\
\hline Contract & 95 & 1.14 & 12,085 & 9,202 canisters & 7,442 \\
\hline Minimum & 87 & 1.04 & 13,205 & 10,054 & 8,131 \\
\hline
\end{tabular}

Source: Hamel 2003 [DIRS 164947], p. 1-9, Tables 1 to 3. 
Table 4-12. Radionuclide Half-Lives

\begin{tabular}{|c|c|c|}
\hline Radionuclide & Half-Life (years) & Data Source \\
\hline${ }^{227} \mathrm{Ac}$ & $2.18 \mathrm{E}+01$ & Parrington et al. 1996 [DIRS 103896] \\
\hline${ }^{241} \mathrm{Am}$ & $4.33 E+02$ & Parrington et al. 1996 [DIRS 103896] \\
\hline${ }^{243} \mathrm{Am}$ & $7.37 \mathrm{E}+03$ & Parrington et al. 1996 [DIRS 103896] \\
\hline${ }^{14} \mathrm{C}$ & $5.72 \mathrm{E}+03$ & Parrington et al. 1996 [DIRS 103896] \\
\hline${ }^{36} \mathrm{Cl}$ & $3.01 \mathrm{E}+05$ & Parrington et al. 1996 [DIRS 103896] \\
\hline${ }^{245} \mathrm{Cm}$ & $8.50 \mathrm{E}+03$ & Parrington et al. 1996 [DIRS 103896] \\
\hline${ }^{135} \mathrm{Cs}$ & $2.30 \mathrm{E}+06$ & Parrington et al. 1996 [DIRS 103896] \\
\hline${ }^{137} \mathrm{Cs}$ & $3.01 \mathrm{E}+01$ & Parrington et al. 1996 [DIRS 103896] \\
\hline${ }^{129} \mathrm{I}$ & $1.57 \mathrm{E}+07$ & Parrington et al. 1996 [DIRS 103896] \\
\hline${ }^{237} \mathrm{~Np}$ & $2.14 \mathrm{E}+06$ & Parrington et al. 1996 [DIRS 103896] \\
\hline${ }^{231} \mathrm{~Pa}$ & $3.28 \mathrm{E}+04$ & Parrington et al. 1996 [DIRS 103896] \\
\hline${ }^{210} \mathrm{~Pb}$ & $2.26 \mathrm{E}+01$ & Parrington et al. 1996 [DIRS 103896] \\
\hline${ }^{238} \mathrm{Pu}$ & 8.77E+01 & Parrington et al. 1996 [DIRS 103896] \\
\hline${ }^{239} \mathrm{Pu}$ & $2.41 \mathrm{E}+04$ & Parrington et al. 1996 [DIRS 103896] \\
\hline${ }^{240} \mathrm{Pu}$ & $6.56 \mathrm{E}+03$ & Parrington et al. 1996 [DIRS 103896] \\
\hline${ }^{241} \mathrm{Pu}$ & $1.44 \mathrm{E}+01$ & Parrington et al. 1996 [DIRS 103896] \\
\hline${ }^{242} \mathrm{Pu}$ & $3.75 E+05$ & Parrington et al. 1996 [DIRS 103896] \\
\hline${ }^{226} \mathrm{Ra}$ & $1.60 \mathrm{E}+03$ & Parrington et al. 1996 [DIRS 103896] \\
\hline${ }^{228} \mathrm{Ra}$ & $5.76 \mathrm{E}+00$ & Parrington et al. 1996 [DIRS 103896] \\
\hline${ }^{79} \mathrm{Se}$ & $2.95 E+05$ & Singh 2002 [DIRS 164741] \\
\hline${ }^{126} \mathrm{Sn}$ & $2.50 \mathrm{E}+05$ & Parrington et al. 1996 [DIRS 103896] \\
\hline${ }^{90} \mathrm{Sr}$ & $2.88 \mathrm{E}+01$ & Parrington et al. 1996 [DIRS 103896] \\
\hline${ }^{99} \mathrm{Tc}$ & $2.13 E+05$ & Parrington et al. 1996 [DIRS 103896] \\
\hline${ }^{229} \mathrm{Th}$ & $7.30 \mathrm{E}+03$ & Parrington et al. 1996 [DIRS 103896] \\
\hline${ }^{230} \mathrm{Th}$ & $7.54 \mathrm{E}+04$ & Parrington et al. 1996 [DIRS 103896] \\
\hline${ }^{232} \mathrm{Th}$ & $1.40 \mathrm{E}+10$ & $\begin{array}{l}\text { Decimal point left out in Parrington et al. } 1996 \\
\text { [DIRS 103896]. Value confirmed by Lide } 1991 \\
\text { [DIRS 131202], pp. } 11 \text { to } 122 .\end{array}$ \\
\hline${ }^{232} \mathrm{U}$ & $6.98 \mathrm{E}+01$ & Parrington et al. 1996 [DIRS 103896] \\
\hline${ }^{233} U$ & $1.59 \mathrm{E}+05$ & Parrington et al. 1996 [DIRS 103896] \\
\hline${ }^{234} \mathrm{U}$ & $2.46 \mathrm{E}+05$ & Parrington et al. 1996 [DIRS 103896] \\
\hline${ }^{235} U$ & $7.04 \mathrm{E}+08$ & Parrington et al. 1996 [DIRS 103896] \\
\hline${ }^{236} U$ & $2.34 \mathrm{E}+07$ & Parrington et al. 1996 [DIRS 103896] \\
\hline${ }^{238} U$ & $4.47 \mathrm{E}+09$ & Parrington et al. 1996 [DIRS 103896] \\
\hline
\end{tabular}

Radionuclide Screening (BSC 2002 [DIRS 160059]) considered two postclosure periods: the 10,000-year regulatory and the million-year FEIS and four release scenarios: (1) nominal, (2) human intrusion, (3) intrusive igneous event, and (4) eruptive igneous event. The screening analysis considered the two types of CSNF: spent boiling water reactor (BWR) fuel and spent pressurized water reactor (PWR) fuel, the U.S. Department of Energy spent nuclear fuel (DSNF), and high-level radioactive waste (HLW). Average and outlying (that is, high burnup, high initial enrichment, low age, or otherwise exceptional) forms of each waste-form type were considered. Table 4-13 lists the radionuclides identified in Table 13 of Radionuclide Screening (BSC 2002 [DIRS 160059]) as those that "may substantially affect repository performance for the exposure 
scenarios and times listed and should be considered in the total system performance assessment modeling for license application." It was also noted that extending the screening from 10,000 years to 20,000 years adds no radionuclides to the list for the 10,000-year regulatory period (BSC 2002 [DIRS 160059], p. 38 and Table 10).

The purpose of the screening analysis was to "identify all of the radionuclides of major importance to dose and virtually all of the marginally important radionuclides." Further analysis determined that precursors to screened-in radionuclides (Table 4-14) should be considered.

Table 4-13. Results of the Screening Analysis

\begin{tabular}{|c|c|c|c|c|}
\hline \multirow[b]{2}{*}{ Radionuclide } & \multicolumn{2}{|c|}{$\begin{array}{c}\text { Nominal, Human-Intrusion, and Intrusive } \\
\text { Igneous Scenarios }\end{array}$} & \multicolumn{2}{|c|}{ Eruptive Igneous Scenario } \\
\hline & $\begin{array}{c}100 \text { to } \\
20,000 \text { years }\end{array}$ & $\begin{array}{l}20,000 \text { to } \\
1 \text { million years }\end{array}$ & $\begin{array}{c}100 \text { to } \\
20,000 \text { years }\end{array}$ & $\begin{array}{c}20,000 \text { to } \\
1 \text { million years }\end{array}$ \\
\hline${ }^{227} \mathrm{Ac}$ & ${ }^{227} \mathrm{Ac}$ & ${ }^{227} \mathrm{Ac}$ & ${ }^{227} \mathrm{Ac}$ & ${ }^{227} \mathrm{Ac}$ \\
\hline${ }^{241} \mathrm{Am}$ & ${ }^{241} \mathrm{Am}$ & & ${ }^{241} \mathrm{Am}$ & \\
\hline${ }^{243} \mathrm{Am}$ & ${ }^{243} \mathrm{Am}$ & ${ }^{243} \mathrm{Am}$ & ${ }^{243} \mathrm{Am}$ & ${ }^{243} \mathrm{Am}$ \\
\hline${ }^{14} \mathrm{C}$ & ${ }^{14} \mathrm{C}$ & ${ }^{14} \mathrm{C}$ & & \\
\hline${ }^{36} \mathrm{Cl}$ & & ${ }^{36} \mathrm{Cl}$ & & \\
\hline${ }^{135} \mathrm{Cs}$ & ${ }^{135} \mathrm{Cs}$ & ${ }^{135} \mathrm{Cs}$ & & \\
\hline${ }^{137} \mathrm{Cs}$ & ${ }^{137} \mathrm{Cs}$ & & ${ }^{137} \mathrm{Cs}$ & \\
\hline${ }^{129} I$ & ${ }^{129} \mathrm{I}$ & ${ }^{129} \mathrm{I}$ & & \\
\hline${ }^{237} \mathrm{~Np}$ & ${ }^{237} \mathrm{~Np}$ & ${ }^{237} \mathrm{~Np}$ & & ${ }^{237} \mathrm{~Np}$ \\
\hline${ }^{231} \mathrm{~Pa}$ & ${ }^{231} \mathrm{~Pa}$ & ${ }^{231} \mathrm{~Pa}$ & & ${ }^{231} \mathrm{~Pa}$ \\
\hline${ }^{210} \mathrm{~Pb}$ & & ${ }^{210} \mathrm{~Pb}$ & & ${ }^{210} \mathrm{~Pb}$ \\
\hline${ }^{238} \mathrm{Pu}$ & ${ }^{238} \mathrm{Pu}$ & & ${ }^{238} \mathrm{Pu}$ & \\
\hline${ }^{239} \mathrm{Pu}$ & ${ }^{239} \mathrm{Pu}$ & ${ }^{239} \mathrm{Pu}$ & ${ }^{239} \mathrm{Pu}$ & ${ }^{239} \mathrm{Pu}$ \\
\hline${ }^{240} \mathrm{Pu}$ & ${ }^{240} \mathrm{Pu}$ & ${ }^{240} \mathrm{Pu}$ & ${ }^{240} \mathrm{Pu}$ & ${ }^{240} \mathrm{Pu}$ \\
\hline${ }^{242} \mathrm{Pu}$ & & ${ }^{242} \mathrm{Pu}$ & & ${ }^{242} \mathrm{Pu}$ \\
\hline${ }^{226} \mathrm{Ra}$ & ${ }^{226} \mathrm{Ra}$ & ${ }^{226} \mathrm{Ra}$ & & ${ }^{226} \mathrm{Ra}$ \\
\hline${ }^{79} \mathrm{Se}$ & & ${ }^{79} \mathrm{Se}$ & & \\
\hline${ }^{126} \mathrm{Sn}$ & & ${ }^{126} \mathrm{Sn}$ & & ${ }^{126} \mathrm{Sn}$ \\
\hline${ }^{90} \mathrm{Sr}$ & ${ }^{90} \mathrm{Sr}$ & & ${ }^{90} \mathrm{Sr}$ & \\
\hline${ }^{99} \mathrm{Tc}$ & ${ }^{99} \mathrm{Tc}$ & ${ }^{99} \mathrm{Tc}$ & & ${ }^{99} \mathrm{Tc}$ \\
\hline${ }^{229} \mathrm{Th}$ & ${ }^{229} \mathrm{Th}$ & ${ }^{229} \mathrm{Th}$ & ${ }^{229} \mathrm{Th}$ & ${ }^{229} \mathrm{Th}$ \\
\hline${ }^{230} \mathrm{Th}$ & & ${ }^{230} \mathrm{Th}$ & & ${ }^{230} \mathrm{Th}$ \\
\hline${ }^{232} \mathrm{Th}$ & & ${ }^{232} \mathrm{Th}$ & & ${ }^{232} \mathrm{Th}$ \\
\hline${ }^{232} \mathrm{U}$ & ${ }^{232} U$ & & ${ }^{232} U$ & \\
\hline${ }^{233} \mathrm{U}$ & ${ }^{233} \mathrm{U}$ & ${ }^{233} \mathrm{U}$ & ${ }^{233} U$ & ${ }^{233} \mathrm{U}$ \\
\hline${ }^{234} \mathrm{U}$ & ${ }^{234} U$ & ${ }^{234} \mathrm{U}$ & ${ }^{234} \mathrm{U}$ & ${ }^{234} \mathrm{U}$ \\
\hline${ }^{236} \mathrm{U}$ & & ${ }^{236} \mathrm{U}$ & & ${ }^{236} \mathrm{U}$ \\
\hline${ }^{238} \mathrm{U}$ & ${ }^{238} \mathrm{U}$ & ${ }^{238} \mathrm{U}$ & & ${ }^{238} \mathrm{U}$ \\
\hline Counts & 20 & 23 & 12 & 18 \\
\hline
\end{tabular}

Source: BSC 2002 [DIRS 160059], Table 13.

NOTES: Extending the screening for the regulatory period to include the 20,000-year screening time adds no radionuclides to the screening lists (BSC 2002 [DIRS 160059], Section 6.3.2). See Section 6.1 for a discussion of additional radionuclides that are added to the radionuclide inventory. 
Table 4-14. Additional Radionuclides Needed for Accurate Accounting of Those Screened In for 10,000 Years

\begin{tabular}{|c|c|c|}
\hline $\begin{array}{l}\text { Nuclide } \\
\text { Examined }\end{array}$ & Discussion & $\begin{array}{c}\text { Additional } \\
\text { Nuclides }\end{array}$ \\
\hline${ }^{227} \mathrm{Ac}$ & Daughter of ${ }^{231} \mathrm{~Pa}$, which is screened in (see Table Note). & - \\
\hline${ }^{241} \mathrm{Am}$ & $\begin{array}{l}{ }^{245} \mathrm{Cm} \rightarrow{ }^{241} \mathrm{Pu} \rightarrow{ }^{241} \mathrm{Am} .{ }^{245} \mathrm{Cm} \text { has a half-life much greater than that of }{ }^{241} \mathrm{Am} \text { and can } \\
\text { provide a source of }{ }^{241} \mathrm{Am} \text {. Toward the end of the regulatory period, }{ }^{241} \mathrm{Am} \text { is in secular } \\
\text { equilibrium with }{ }^{245} \mathrm{Cm} \text {. Also, }{ }^{245} \mathrm{Bk} \rightarrow{ }^{241} \mathrm{Am} \text {, but }{ }^{245} \mathrm{Bk} \text { does not appear in the waste } \\
\text { forms used for the screening analysis. }\end{array}$ & ${ }^{241} \mathrm{Pu}{ }^{245} \mathrm{Cm}$ \\
\hline${ }^{243} \mathrm{Am}$ & 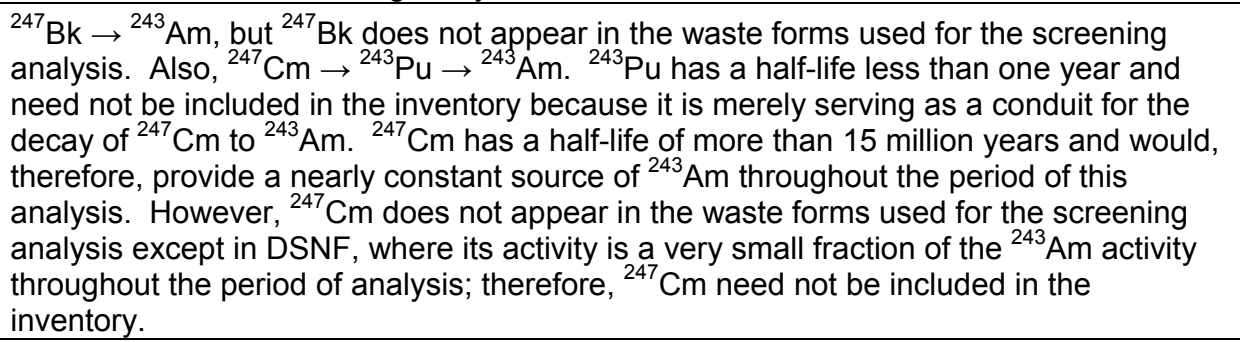 & - \\
\hline${ }^{14} \mathrm{C}$ & $\begin{array}{l}\text { Activation product; not produced by the decay of anything in the waste forms used for } \\
\text { the screening analysis. }\end{array}$ & - \\
\hline${ }^{36} \mathrm{Cl}$ & $\begin{array}{l}\text { Activation product; not produced by the decay of anything in the waste forms used for } \\
\text { the screening analysis. }\end{array}$ & - \\
\hline${ }^{135} \mathrm{Cs}$ & $\begin{array}{l}\text { Fission product; not produced by the decay of anything in the waste forms used for the } \\
\text { screening analysis }\end{array}$ & - \\
\hline${ }^{137} \mathrm{Cs}$ & $\begin{array}{l}\text { Fission product; not produced by the decay of anything in the waste forms used for the } \\
\text { screening analysis }\end{array}$ & - \\
\hline 129 & $\begin{array}{l}\text { Fission product; not produced by the decay of anything in the waste forms used for the } \\
\text { screening analysis }\end{array}$ & - \\
\hline${ }^{237} \mathrm{~Np}$ & $\begin{array}{l}\text { Decay product of }{ }^{241} \mathrm{Am} \text {, which is screened in. Also produced by decay of }{ }^{237} \mathrm{U} \text {, which } \\
\text { is produced by a minor branch of the decay of }{ }^{241} \mathrm{Pu} .{ }^{237} \mathrm{U} \text { has a half-life less than one } \\
\text { year and need not be included in the initial inventory because it is merely serving as a } \\
\text { conduit for the decay of }{ }^{241} \mathrm{Pu} \text { to }{ }^{237} \mathrm{~Np} \text {. }{ }^{241} \mathrm{Pu} \text { is listed above as needed for the } \\
\text { inventory. }\end{array}$ & - \\
\hline${ }^{231} \mathrm{~Pa}$ & $\begin{array}{l}{ }^{235} \mathrm{U} \rightarrow{ }^{231} \mathrm{Th} \rightarrow{ }^{231} \mathrm{~Pa} .{ }^{231} \mathrm{Th} \text { has a half-life less than one year and need not be } \\
\text { included in the initial inventory because it is merely serving as a conduit for the decay of } \\
{ }^{235} \mathrm{U} \text { to }{ }^{231} \mathrm{~Pa} \text {. } \\
\text { waste forms and its invenent in the waste forms is needed to accurately project the inventory of }{ }^{231} \mathrm{~Pa} \text {, } \\
\text { especially for times beyond the regulatory period. }\end{array}$ & ${ }^{235} \mathrm{U}$ \\
\hline${ }^{210} \mathrm{~Pb}$ & $\begin{array}{l}{ }^{226} \mathrm{Ra} \rightarrow{ }^{210} \mathrm{~Pb} \text { through a series of short-lived radionuclides that need not be included in } \\
\text { the inventory. }{ }^{226} \mathrm{Ra} \text { is screened in wherever }{ }^{210} \mathrm{~Pb} \text { is screened in. }\end{array}$ & - \\
\hline${ }^{238} \mathrm{Pu}$ & $\begin{array}{l}{ }^{242 \mathrm{~m}} \mathrm{Am} \rightarrow{ }^{242} \mathrm{Am} \rightarrow{ }^{242} \mathrm{Cm} \rightarrow{ }^{238} \mathrm{Pu} .{ }^{242} \mathrm{Cm} \text { and }{ }^{242} \mathrm{Am} \text { have half-lives less than one } \\
\text { year and need not be included in the inventory because they are merely serving as a } \\
\text { conduit for the decay of }{ }^{242 \mathrm{~m}} \mathrm{Am} \text { to }{ }^{238} \mathrm{Pu} \text {. Also }{ }^{242 \mathrm{~m}} \mathrm{Am} \rightarrow{ }^{238} \mathrm{~Np} \rightarrow{ }^{238} \mathrm{Pu} .{ }^{238} \mathrm{~Np} \text { has a } \\
\text { half-life of less than one year and need not be included in the inventory. }{ }^{242 \mathrm{~m}} \mathrm{Am} \text { has a } \\
\text { longer half-life than }{ }^{238} \mathrm{Pu} \text {, so could conceivably provide a source of }{ }^{238} \mathrm{Pu} \text { worth } \\
\text { tracking in TSPA-LA. However, although }{ }^{242 \mathrm{~m}} \mathrm{Am} \text { shows up in BWR, DSNF, HLW, and } \\
\mathrm{PWR} \text { waste forms, in each case, the }{ }^{242 \mathrm{~m}} \mathrm{Am} \text { activity is negligible compared to that of } \\
{ }^{238} \mathrm{Pu} \text {. }\end{array}$ & - \\
\hline${ }^{239} \mathrm{Pu}$ & $\begin{array}{l}{ }^{243} \mathrm{Am} \rightarrow{ }^{239} \mathrm{~Np} \rightarrow{ }^{239} \mathrm{Pu} . \\
\text { included in the inventory. }{ }^{239} \mathrm{~Np} \text { has a half-life less than one year and need not be } \\
\text { in BWR, DSNF, HLW, and PWR waste forms, } \mathrm{n} \text {. Also, but in each case, the }{ }^{243} \mathrm{Pu} \text {. }{ }^{243} \mathrm{Cm} \text { activity is } \\
\text { negligible compared to that of }{ }^{239} \mathrm{Pu} \text {. }\end{array}$ & - \\
\hline
\end{tabular}


Table 4-14. Additional Radionuclides Needed for Accurate Accounting of Those Screened In for 10,000 Years (Continued)

\begin{tabular}{|c|c|c|}
\hline $\begin{array}{l}\text { Nuclide } \\
\text { Examined }\end{array}$ & Discussion & $\begin{array}{l}\text { Additional } \\
\text { Nuclides }\end{array}$ \\
\hline${ }^{240} \mathrm{Pu}$ & $\begin{array}{l}{ }^{244} \mathrm{Cm} \rightarrow{ }^{240} \mathrm{Pu} .{ }^{244} \mathrm{Cm} \text { has a half-life much shorter than that of }{ }^{240} \mathrm{Pu} \text {. For that reason, } \\
\text { its initial activity would have to be much greater than that of }{ }^{240} \mathrm{Pu} \text { to significantly affect } \\
\text { the activity of }{ }^{240} \mathrm{Pu} \text {. This claim can be verified as follows: A necessary condition for } \\
\text { the inventory of the parent radionuclide to significantly affect that of the daughter is that } \\
\text { the number of atoms in initial inventory for the parent Np be at least comparable to that } \\
\text { of the daughter, } \mathrm{Nd} \text {. That is, } \mathrm{Np} \cong \mathrm{Nd} \text { or } \mathrm{Np}>\mathrm{Nd} \text {. In this case, because the half-life of } \\
\text { the parent is much less than that of the daughter, the relationship between the decay } \\
\text { constants is } \lambda p>>\lambda \text {. Given the required relationship of the numbers of atoms Np and } \\
\mathrm{Nd} \text {, the necessary condition stated in terms of activities }(\mathrm{A}=\mathrm{N} \lambda) \text { is } \mathrm{Np} \lambda \mathrm{p}>>\mathrm{Nd} \lambda \mathrm{d} \text {. As it } \\
\text { happens, the necessary condition is not met because the initial }{ }^{244} \mathrm{Cm} \text { activity in the } \\
\text { waste forms that were used for the screening analysis is less than the initial }{ }^{240} \mathrm{Pu} \\
\text { activity. Therefore, }{ }^{244} \mathrm{Cm} \text { need not be included in the inventory. }\end{array}$ & - \\
\hline${ }^{242} \mathrm{Pu}$ & $\begin{array}{l}{ }^{246} \mathrm{Cm} \rightarrow{ }^{242} \mathrm{Pu} .{ }^{246} \mathrm{Cm} \text { has a half-life much shorter than that of }{ }^{242} \mathrm{Pu} \text {. For that reason, } \\
\text { its activity would have to be much higher than that of }{ }^{242} \mathrm{Pu} \text { to significantly affect the } \\
\text { activity of }{ }^{242} \mathrm{Pu} \text { (See the discussion for }{ }^{240} \mathrm{Pu} \text { for a justification of this claim). As it } \\
\text { happens, the initial }{ }^{246} \mathrm{Cm} \text { activity in the waste forms that were used for the screening } \\
\text { analysis is less than the initial }{ }^{242} \mathrm{Pu} \text { activity. Therefore, }{ }^{246} \mathrm{Cm} \text { need not be included in } \\
\text { the inventory. }\end{array}$ & - \\
\hline${ }^{226} \mathrm{Ra}$ & Decay product of ${ }^{230} \mathrm{Th}$, which is screened in & - \\
\hline${ }^{228} \mathrm{Ra}$ & Decay product of ${ }^{232} \mathrm{Th}$, which is screened in & - \\
\hline${ }^{79} \mathrm{Se}$ & $\begin{array}{l}\text { Fission product; not produced by the decay of anything in the waste forms used for the } \\
\text { screening analysis }\end{array}$ & - \\
\hline${ }^{126} \mathrm{Sn}$ & $\begin{array}{l}\text { Fission product; not produced by the decay of anything in the waste forms used for the } \\
\text { screening analysis }\end{array}$ & - \\
\hline${ }^{90} \mathrm{Sr}$ & $\begin{array}{l}\text { Fission product; not produced by the decay of anything in the waste forms used for the } \\
\text { screening analysis }\end{array}$ & - \\
\hline${ }^{99} \mathrm{Tc}$ & $\begin{array}{l}\text { Fission product; not produced by the decay of anything in the waste forms used for the } \\
\text { screening analysis }\end{array}$ & - \\
\hline${ }^{229} \mathrm{Th}$ & Decay product of ${ }^{233} \mathrm{U}$, which is screened in & - \\
\hline${ }^{230} \mathrm{Th}$ & Decay product of ${ }^{234} U$, which is screened in & - \\
\hline${ }^{232} \mathrm{Th}$ & Decay product of ${ }^{236} U$, which is screened in & - \\
\hline${ }^{232} U$ & $\begin{array}{l}\text { Decay product of }{ }^{236} \mathrm{Pu} \text {, which has a half-life of about } 3 \text { years. With such a short half- } \\
\text { life, by the time the waste is received at the repository, most of the }{ }^{236} \mathrm{Pu} \text { will have } \\
\text { decayed to }{ }^{232} \mathrm{U} \text {. In any case, }{ }^{236} \mathrm{Pu} \text { has a half-life much shorter than that of }{ }^{232} \mathrm{U} \text {. For } \\
\text { that reason, its activity would have to be much higher than that of }{ }^{232} \mathrm{U} \text { to significantly } \\
\text { affect the activity of }{ }^{232} \cup\left(\text { See the discussion for }{ }^{240} \mathrm{Pu} \text { for a justification of this claim). }\right. \\
\text { As it happens, the initial }{ }^{236} \mathrm{Pu} \text { activity in the waste forms that were used for the } \\
\text { screening analysis is less than the initial }{ }^{232} \mathrm{U} \text { activity. Therefore, }{ }^{236} \mathrm{Pu} \text { need not be } \\
\text { included in the inventory. }\end{array}$ & - \\
\hline${ }^{233} \mathrm{U}$ & $\begin{array}{l}{ }^{237} \mathrm{~Np} \rightarrow{ }^{233} \mathrm{~Pa} \rightarrow{ }^{233} \mathrm{U} .{ }^{237} \mathrm{~Np} \text { is screened in. }{ }^{233} \mathrm{~Pa} \text { has a half-life less than one year } \\
\text { and need not be included in the inventory. }\end{array}$ & - \\
\hline${ }^{234} \mathrm{U}$ & $\begin{array}{l}{ }^{238} \mathrm{U} \rightarrow{ }^{234} \mathrm{Th} \rightarrow{ }^{234} \mathrm{~Pa} \rightarrow{ }^{234} \mathrm{U} .{ }^{238} \mathrm{U} \text { is screened in. }{ }^{234} \mathrm{~Pa} \text { and }{ }^{234} \mathrm{Th} \text { have half-lives less } \\
\text { than } 1 \text { year and need not be included in the inventory. }\end{array}$ & - \\
\hline${ }^{236} U$ & Decay product of ${ }^{240} \mathrm{Pu}$, which is screened in & - \\
\hline${ }^{238} \mathrm{U}$ & Decay product of ${ }^{242} \mathrm{Pu}$, which is screened in & - \\
\hline
\end{tabular}

Source: BSC 2002 [DIRS 160059], Table 12.

NOTE: Radionuclide Screening (BSC 2002 [DIRS 160059], p. 38) states that the radionuclides shown in the far right column should be included for the inventory either by direct inclusion or by appropriate augmentation of the daughter product.

See Parrington et al. 1996 [DIRS 103896] for decay relationships and half-lives. 
Table 4-15 presents the nuclear reactions and half-lives of those elements that make up the composition of BWR and PWR assembly hardware that provide the basis for identifying activation products.

Table 4-15. Identification and Screening Status of CSNF PWR and BWR Hardware-Activation Products

\begin{tabular}{|c|c|}
\hline Element & $\begin{array}{l}\text { Nuclear Reactions Considered } \\
\text { (Half-Lives in Parentheses) }^{\mathrm{a}}\end{array}$ \\
\hline $\mathrm{Al}$ & ${ }^{27} \mathrm{Al}(\mathrm{n}, \gamma){ }^{28} \mathrm{Al}(2 \mathrm{~min}) \rightarrow{ }^{28} \mathrm{Si}$ (stable) \\
\hline $\mathrm{B}$ & ${ }^{11} \mathrm{~B}(\mathrm{n}, \gamma){ }^{12} \mathrm{~B}(20 \mathrm{~ms}) \rightarrow{ }^{12} \mathrm{C}$ (stable) \\
\hline C & ${ }^{13} \mathrm{C}(\mathrm{n}, \gamma){ }^{14} \mathrm{C}\left(5.7 \times 10^{3} \mathrm{yr}\right)$ \\
\hline Co & ${ }^{59} \mathrm{Co}(\mathrm{n}, \gamma){ }^{60} \mathrm{Co}(5.3 \mathrm{yr})$ \\
\hline \multirow[t]{2}{*}{$\mathrm{Cr}$} & ${ }^{50} \mathrm{Cr}(\mathrm{n}, \gamma){ }^{51} \mathrm{Cr}(27$ days $) \rightarrow{ }^{51} \mathrm{~V}($ stable $)$ \\
\hline & ${ }^{54} \mathrm{Cr}(\mathrm{n}, \gamma){ }^{55} \mathrm{Cr}(3 \mathrm{~min}) \rightarrow{ }^{55} \mathrm{Mn}$ (stable) \\
\hline \multirow[t]{2}{*}{$\mathrm{Cu}$} & ${ }^{63} \mathrm{Cu}(\mathrm{n}, \gamma){ }^{64} \mathrm{Cu}(13 \mathrm{hr}) \rightarrow{ }^{64} \mathrm{Zn}$ (stable), ${ }^{64} \mathrm{Ni}$ (stable) \\
\hline & ${ }^{65} \mathrm{Cu}(\mathrm{n}, \gamma){ }^{66} \mathrm{Cu}(5 \mathrm{~min}) \rightarrow{ }^{66} \mathrm{Zn}($ stable $)$ \\
\hline \multirow[t]{3}{*}{$\mathrm{Fe}$} & ${ }^{54} \mathrm{Fe}(\mathrm{n}, \gamma){ }^{55} \mathrm{Fe}(2.7 \mathrm{yr}) \rightarrow{ }^{55} \mathrm{Mn}$ (stable) \\
\hline & ${ }^{54} \mathrm{Fe}(\mathrm{n}, \alpha){ }^{51} \mathrm{Cr}(27$ days $) \rightarrow{ }^{51} \mathrm{~V}$ (stable) \\
\hline & ${ }^{58} \mathrm{Fe}(\mathrm{n}, \gamma){ }^{59} \mathrm{Fe}(45$ days $) \rightarrow{ }^{59} \mathrm{Co}$ (stable) \\
\hline $\mathrm{Mn}$ & ${ }^{55} \mathrm{Mn}(\mathrm{n}, \gamma){ }^{56} \mathrm{Mn}(2.6 \mathrm{hr}) \rightarrow{ }^{56} \mathrm{Fe}$ (stable) \\
\hline \multirow[t]{3}{*}{ Mo } & ${ }^{92} \mathrm{Mo}(\mathrm{n}, \gamma){ }^{93} \mathrm{Mo}(6.9 \mathrm{hr}) \rightarrow{ }^{93} \mathrm{Nb}$ (stable) \\
\hline & ${ }^{98} \mathrm{Mo}(\mathrm{n}, \gamma){ }^{99} \mathrm{Mo}(2.7$ days $) \rightarrow{ }^{99} \mathrm{Tc}\left(2.1 \times 10^{5} \mathrm{yr}\right)$ \\
\hline & ${ }^{100} \mathrm{Mo}(\mathrm{n}, \gamma){ }^{101} \mathrm{Mo}(15 \mathrm{~min}) \rightarrow{ }^{101} \mathrm{Tc}(14 \mathrm{~min}) \rightarrow{ }^{100} \mathrm{Ru}($ stable $)$ \\
\hline \multirow[t]{2}{*}{$N$} & ${ }^{14} \mathrm{~N}(\mathrm{n}, \mathrm{p}){ }^{14} \mathrm{C}\left(5.7 \times 10^{3} \mathrm{y}\right)$ \\
\hline & ${ }^{15} \mathrm{~N}(\mathrm{n}, \gamma){ }^{16} \mathrm{~N}(7 \mathrm{sec}) \rightarrow{ }^{16} \mathrm{O}$ (stable) \\
\hline $\mathrm{Nb}$ & ${ }^{93} \mathrm{Nb}(\mathrm{n}, \gamma){ }^{94} \mathrm{Nb}\left(2.0 \times 10^{4} \mathrm{yr}\right)$ \\
\hline \multirow[t]{3}{*}{$\mathrm{Ni}$} & ${ }^{58} \mathrm{Ni}(\mathrm{n}, \gamma)^{59} \mathrm{Ni}\left(7.6 \times 10^{4} \mathrm{yr}\right)$ \\
\hline & ${ }^{62} \mathrm{Ni}(\mathrm{n}, \gamma){ }^{63} \mathrm{Ni}\left(1 \times 10^{2} \mathrm{yr}\right)$ \\
\hline & ${ }^{64} \mathrm{Ni}(\mathrm{n}, \gamma){ }^{63} \mathrm{Ni}(2.5 \mathrm{hr}) \rightarrow{ }^{65} \mathrm{Cu}$ (stable) \\
\hline \multirow[t]{2}{*}{ O } & ${ }^{18} \mathrm{O}(\mathrm{n}, \gamma){ }^{19} \mathrm{O}(27 \mathrm{sec}) \rightarrow{ }^{19} \mathrm{~F}$ (stable) \\
\hline & ${ }^{17} \mathrm{O}(\mathrm{n}, \alpha){ }^{14} \mathrm{C}\left(5.7 \times 10^{3} \mathrm{yr}\right)$ \\
\hline $\mathrm{P}$ & ${ }^{31} \mathrm{P}(\mathrm{n}, \gamma){ }^{32} \mathrm{P}(14$ days $) \rightarrow{ }^{32} \mathrm{~S}$ (stable) \\
\hline \multirow[t]{2}{*}{ s } & ${ }^{34} \mathrm{~S}(\mathrm{n}, \gamma){ }^{35} \mathrm{~S}$ (87 days) $\rightarrow{ }^{35} \mathrm{Cl}$ (stable) \\
\hline & ${ }^{36} \mathrm{~S}(\mathrm{n}, \gamma){ }^{37} \mathrm{~S}$ (87 days) $\rightarrow{ }^{37} \mathrm{Cl}$ (stable) \\
\hline $\mathrm{Si}$ & ${ }^{30} \mathrm{Si}(\mathrm{n}, \gamma){ }^{31} \mathrm{Si}(2.6 \mathrm{hr}) \rightarrow{ }^{31} \mathrm{P}$ (stable) \\
\hline \multirow[t]{4}{*}{$\mathrm{Sn}$} & ${ }^{112} \mathrm{Sn}(\mathrm{n}, \gamma){ }^{113} \mathrm{Sn}(115$ days $) \rightarrow{ }^{113} \ln$ (stable) \\
\hline & ${ }^{120} \mathrm{Sn}(\mathrm{n}, \gamma){ }^{121} \mathrm{Sn}(1.1$ days $) \rightarrow{ }^{121} \mathrm{Sb}$ (stable) \\
\hline & ${ }^{122} \mathrm{Sn}(\mathrm{n}, \gamma){ }^{123} \mathrm{Sn}(129$ days $) \rightarrow{ }^{123} \mathrm{Sb}$ (stable) \\
\hline & ${ }^{124} \mathrm{Sn}(\mathrm{n}, \gamma){ }^{125} \mathrm{Sn}(9.6$ days $) \rightarrow{ }^{125} \mathrm{Sb}(2.7 \mathrm{yr})$ \\
\hline $\mathrm{Ti}$ & ${ }^{50} \mathrm{Ti}(\mathrm{n}, \gamma){ }^{51} \mathrm{Ti}(5.8 \mathrm{~min}) \rightarrow{ }^{51} \mathrm{~V}$ (stable) \\
\hline \multirow[t]{3}{*}{$\mathrm{Zr}$} & ${ }^{92} \mathrm{Zr}(\mathrm{n}, \gamma){ }^{93} \mathrm{Zr}\left(1.5 \times 10^{6} \mathrm{yr}\right)$ \\
\hline & ${ }^{94} \mathrm{Zr}(\mathrm{n}, \gamma){ }^{95} \mathrm{Zr}$ (64 days) $\rightarrow{ }^{95} \mathrm{Nb}$ (35 days) $\rightarrow{ }^{95} \mathrm{Mo}$ (stable) \\
\hline & ${ }^{96} \mathrm{Zr}(\mathrm{n}, \gamma){ }^{97} \mathrm{Zr}(17 \mathrm{hr}) \rightarrow{ }^{97} \mathrm{Nb}(1.2 \mathrm{~h}) \rightarrow{ }^{97} \mathrm{Mo}($ stable $)$ \\
\hline
\end{tabular}

Source: Parrington et al. 1996 [DIRS 103896].

NOTES: ${ }^{a}$ Activation of reaction products ignored. 
Table 4-16 provides the ${ }^{14} \mathrm{C}$ and ${ }^{99} \mathrm{Tc}$ inventories expected in 5-year-old and 25-year-old PWR and BWR assemblies (BSC 2004 [DIRS 171435]; BSC 2004 [DIRS 171436]). These tables are used in Appendix I to evaluate neutron-activation products outside the spent-fuel matrix and their contribution to the radionuclide inventory. The values are intended to be bounding.

Table 4-16. ${ }^{99} \mathrm{Tc}$ and ${ }^{14} \mathrm{C}$ Inventories of BWR Assembly at Specified Characteristics

\begin{tabular}{|c|c|c|c|c|c|c|c|c|c|c|c|c|}
\hline & \multirow{2}{*}{\multicolumn{3}{|c|}{$\begin{array}{c}\text { Average BWR SNF } \\
\text { Assembly } \\
(3.5 \%, 40 \mathrm{GWd} / \mathrm{MTU}, \\
25 \text { years })\end{array}$}} & \multirow{2}{*}{\multicolumn{3}{|c|}{$\begin{array}{c}\begin{array}{c}\text { Bounding BWR SNF } \\
\text { Assembly }\end{array} \\
\begin{array}{c}(5.0 \%, 75 \mathrm{GWd} / \mathrm{MTU}, \\
5 \text { years })\end{array} \\
\end{array}$}} & \multirow{2}{*}{\multicolumn{3}{|c|}{$\begin{array}{c}\text { Average PWR SNF } \\
\text { Assembly } \\
(4.0 \%, 48 \mathrm{GWd} / \mathrm{MTU}, \\
25 \text { years }) \\
\end{array}$}} & \multicolumn{3}{|c|}{$\begin{array}{c}\text { Bounding PWR SNF } \\
\text { Assembly }\end{array}$} \\
\hline & & & & & & & & & & \multicolumn{3}{|c|}{$(5.0 \%, 80 \mathrm{GWd} / \mathrm{MTU}, 5$ years } \\
\hline & \begin{tabular}{|c|}
$\begin{array}{c}\text { Fission } \\
\text { Products }\end{array}$ \\
${ }^{99} \mathrm{Tc}$ \\
\end{tabular} & ${ }^{14} \mathrm{C}$ & ${ }^{99} \mathrm{Tc}$ & \begin{tabular}{|c|}
$\begin{array}{c}\text { Fission } \\
\text { Products }\end{array}$ \\
${ }^{99} \mathrm{Tc}$ \\
\end{tabular} & ${ }^{14} \mathrm{C}$ & ${ }^{99} \mathrm{Tc}$ & \begin{tabular}{|c|}
$\begin{array}{c}\text { Fission } \\
\text { Products }\end{array}$ \\
${ }^{99} \mathrm{Tc}$ \\
\end{tabular} & ${ }^{14} \mathrm{C}$ & ${ }^{99} \mathrm{Tc}$ & \begin{tabular}{|c|}
$\begin{array}{c}\text { Fission } \\
\text { Products }\end{array}$ \\
${ }^{99} \mathrm{Tc}$ \\
\end{tabular} & ${ }^{14} \mathrm{C}$ & ${ }^{99} \mathrm{Tc}$ \\
\hline Bottom & & $2.44 \times 10^{-2}$ & $0.00 \times 10^{0}$ & & $4.39 \times 10^{-2}$ & $0.00 \times 10^{0}$ & & $0.00 \times 10^{0}$ & $2.91 \times 10^{-4}$ & & $0.00 \times 10^{0}$ & $4.63 \times 10^{-4}$ \\
\hline Plenum & & $4.11 \times 10^{-3}$ & $0.00 \times 10^{0}$ & & $7.39 \times 10^{-3}$ & $0.00 \times 10^{0}$ & & $0.00 \times 10^{0}$ & $3.78 \times 10^{-5}$ & & $0.00 \times 10^{0}$ & $6.04 \times 10^{-5}$ \\
\hline Top & & $6.85 \times 10^{-3}$ & $0.00 \times 10^{0}$ & & $1.23 \times 10^{-2}$ & $0.00 \times 10^{0}$ & & $2.26 \times 10^{-3}$ & $1.58 \times 10^{-4}$ & & $3.62 \times 10^{-3}$ & $2.51 \times 10^{-4}$ \\
\hline TOTAL & $3.20 \times 10^{0}$ & $1.75 \times 10^{-1}$ & $0.00 \times 10^{0}$ & $5.35 \times 10^{0}$ & $3.16 \times 10^{-1}$ & $1.34 \times 10-5$ & $8.99 \times 10^{0}$ & $3.32 \times 10^{-1}$ & $1.10 \times 10^{-3}$ & $1.34 \times 10^{1}$ & $5.35 \times 10^{-1}$ & $1.76 \times 10^{-3}$ \\
\hline
\end{tabular}

Source: BSC 2004 [DIRS 171435], Table 6; BSC 2004 [DIRS 171436], Table 12.

NOTE: $\quad 0.00 \times 10^{0}$ is the value presented in the data input source.

\subsection{CRITERIA}

Criteria addressed by Technical Work Plan For: Regulatory Integration Modeling and Analysis of the Waste Form and Waste Package (BSC 2004 [DIRS 171583], Section 3) and applicable to this analysis are presented in Sections 4.2 and 4.3.

Section 3.4 of Project Requirements Document (Canori and Leitner 2003 [DIRS 166275]) contains requirements relevant to this analysis. The key requirements (referred to by their requirement identifier) are:

1. PRD-002/T-014 (Canori and Leitner 2003 [DIRS 166275], p. 3-14) "Performance Objectives for the Geologic Repository after Permanent Closure" (traceable to 10 CFR 63.113 [DIRS 156605]).

This section specifies the repository performance objectives that must be met following permanent closure. It includes a requirement for multiple barriers and limits on radiological exposure.

2. PRD-002/T-015 (Canori and Leitner 2003 [DIRS 166275], p. 3-14) "Requirements for Performance Assessment”" (traceable to 10 CFR 63.114 [DIRS 156605]).

This section specifies the technical requirements to be used in performing a performance assessment. It includes requirements for calculations, including data related to site geology, hydrology, variability in the models, and deterioration or degradation processes, including waste form degradation. 
Work described in this document support these requirements, but more specific criteria exist in Section 2.2.1 of Yucca Mountain Review Plan, Final Report (NRC 2003 [DIRS 163274]). Selected acceptance criteria are presented to supplement or clarify Project Requirements Document (Canori and Leitner 2003 [DIRS 166275]) citation. The following acceptance criteria were identified in the technical work plan as applicable to this analysis. Section 7.2 quotes the full text of the applicable acceptance criteria with pointers to the information within this report that pertains to the criteria.

Radionuclide Release Rates Acceptance Criteria (NRC 2003 [DIRS 163274], Section 2.2.1.3.4.3):

- Acceptance Criterion 1-System Description and Model Integration are Adequate

- Acceptance Criterion 2-Data are Sufficient for Model Justification

- Acceptance Criterion 3-Data Uncertainty is Characterized and Propagated Through the Model Abstraction.

Section 3.3 of Technical Work Plan For: Regulatory Integration Modeling and Analysis of the Waste Form and Waste Package (BSC 2004 [DIRS 171583]) addresses "other acceptance or completion criteria." Technical products are required to address and document the accuracy, precision, and representativeness of the work performed as part of the uncertainty analyses. In addition, technical products will meet the level of detail and accuracy needed to support the TSPA-LA model.

\subsection{CODES, STANDARDS, AND REGULATIONS}

Section 3.1 of Technical Work Plan For: Regulatory Integration Modeling and Analysis of the Waste Form and Waste Package (BSC 2004 [DIRS 171583]) states that this work will conform, as appropriate, to guidance provided in ASTM C 1174-97 [DIRS 105725], Standard Practice for Prediction of the Long-Term Behavior of Materials, Including Waste Forms, Used in Engineered Barrier Systems (EBS) for Geological Disposal of High-Level Radioactive Waste. This analysis conforms to this guidance in that it conforms "to methods used to aid in the prediction of the long-term behavior of materials, such as 'engineered barrier' system (EBS) materials and waste forms, used in the geologic disposal of high-level nuclear waste in the U.S. Government disposal site."

Section 3.2 of Technical Work Plan For: Regulatory Integration Modeling and Analysis of the Waste Form and Waste Package (BSC 2004 [DIRS 171583]) states that 10 CFR Part 63 [DIRS 156605] is applicable to this work. Certain sections of 10 CFR Part 63 [DIRS 156605] and 40 CFR Part 197 [DIRS 165519] are relevant to the use of the results from analyses performed as a part of the Total System Performance Assessment for the License Application (TSPA-LA). The output from this analysis will be used in the TSPA-LA postclosure analysis. 


\section{INTENTIONALLY LEFT BLANK}




\section{ASSUMPTIONS}

There are many assumptions that have been made in the development of the source documents used in this analysis. The assumptions relevant to the data used in this analysis are provided here.

\subsection{COMMERCIAL SPENT NUCLEAR FUEL}

The data presented in this analysis that was used to characterize the CSNF radionuclide inventory was based on calculations that compiled commercial waste stream information from several sources (CRWMS M\&O 2000 [DIRS 138239]). In order to derive the number of waste packages for each waste package design configuration, the average initial burnup (GWd/MTU) and the radionuclide inventory in curies for the year of expected completion of emplacement (2033), assumptions were made. Source term information for a Babcock \& Wilcox Mark B PWR assembly with initial heavy metal loading of $475 \mathrm{~kg}$ was chosen (to develop the inputs to this analysis) because it has characteristics that are considered generally "representative" of other PWR assemblies. Therefore, it was assumed that the source term values from the Mark B assemblies are representative and can be applied to other PWR assemblies of different classes and initial uranium loading by a simple ratio of the initial uranium loading. This assumption is verified in PWR and BWR Source Term Sensitivity Study (BSC 2004 [DIRS 167058]).

Similarly, source term information was developed for a General Electric 2/3 BWR assembly with an initial heavy metal loading of $200 \mathrm{~kg}$. This assembly was chosen because it has characteristics that are "representative" of other BWR assemblies. It was assumed that source term values from this assembly could be applied to other BWR assemblies of different classes and initial uranium loading by a simple ratio of the initial uranium loading. This assumption is also verified in $P W R$ and BWR Source Term Sensitivity Study (BSC 2004 [DIRS 167058]).

Assumptions were also made as to the loading of assemblies of different types into the various waste package configurations. Although the specific criteria for loading assemblies is not yet known, it was assumed that no thermal criteria will be violated so long as the mix of assemblies placed into a waste package are below the maximum allowable limit (CRWMS M\&O 2000 [DIRS 138239]). Since it is unknown which assemblies the utilities will send at a given time, arrival forecasts were developed based on three different arrival "case" methodologies to account for the most likely scenarios. These were presented in Section 4.1, and Tables 4-5 and 4-6.

\subsection{DOE-OWNED SPENT NUCLEAR FUEL}

The National Spent Fuel Program has noted that complete information is not available for many DSNFs. In the absence of some information needed to calculate scaling factors, assumptions that tend to err toward a more conservative result were used (DOE 2003 [DIRS 163377], p. 21). These assumptions are intended to cause a conservative bias such that the resulting estimate will predict a source term with a higher dose. Table 5-1 contains assumptions suggested when information is incomplete. 
Table 5-1. Assumptions Related to DSNF

\begin{tabular}{|c|c|c|}
\hline $\begin{array}{l}\text { Unknown } \\
\text { Parameter }\end{array}$ & Conservative Assumption & Basis \\
\hline Cladding & $\begin{array}{l}\text { If cladding is unknown, assume it is } \\
\text { stainless steel }\end{array}$ & $\begin{array}{l}\text { Stainless steel is more conducive to the production } \\
\text { of activation products than that of other typical } \\
\text { cladding materials (e.g., aluminum, zirconium, } \\
\text { graphite). }\end{array}$ \\
\hline Fuel compound & $\begin{array}{l}\text { If end-of-life plutonium exceeds } 1 \% \\
\text { by weight, assume a mixed oxide } \\
\text { fuel. } \\
\text { If thorium is present at end-of-life, } \\
\text { assume a U-Th oxide fuel. } \\
\text { Otherwise, assume a uranium fuel. }\end{array}$ & $\begin{array}{l}\text { Because the majority of spent nuclear fuels (SNFs) } \\
\text { are uranium fuels, this is assumed unless } \\
\text { information provides evidence of other fuel } \\
\text { compounds. }\end{array}$ \\
\hline BOL enrichment & $\begin{array}{l}\text { Assume the initial fissile mass equals } \\
\text { the fissile mass depleted (i.e., } 100 \% \\
\text { depletion). } \\
\text { If needed, the initial uranium } \\
\text { inventory can be estimated as the } \\
\text { end-of-life heavy metal mass plus the } \\
\text { initial fissile mass. }\end{array}$ & $\begin{array}{l}\text { Estimates the lowest possible enrichment (i.e., will } \\
\text { underpredict the actual enrichment). } \\
\text { These correlations assume uranium fuels. Uranium } \\
\text { fuels comprise the majority of DSNFs. These } \\
\text { correlations also provide reasonable } \\
\text { approximations for other fuel types. }\end{array}$ \\
\hline Moderator & Heavy water. & $\begin{array}{l}\text { Heavy water moderation produces a soft neutron } \\
\text { spectrum that is generally more conducive to } \\
\text { transmutation of heavy metals }\end{array}$ \\
\hline $\begin{array}{l}\text { Reactor shutdown } \\
\text { or fuel removal } \\
\text { date }\end{array}$ & $\begin{array}{l}\text { Date for fuel shipping, storage, or any } \\
\text { other activity that confirms the fuel } \\
\text { was no longer in the reactor. }\end{array}$ & $\begin{array}{l}\text { Use of later date will produce a conservative result } \\
\text { for all radionuclides of interest except }{ }^{237} \mathrm{~Np} \text { and } \\
{ }^{241} \mathrm{Am} \text { because, for a period, they may increase } \\
\text { rather that decrease. }\end{array}$ \\
\hline
\end{tabular}

Source: DOE 2003 [DIRS 163377], Table 1.

The CSNF bare fuel that is in DOE's possession is not included in this analysis. Source Term Estimates for DOE Spent Nuclear Fuels (DOE 2003 [DIRS 163377]) provides the inventory for DSNF. This analysis excludes the part of that inventory associated with bare fuel and assumes that the remaining inventory is conservative for TSPA-LA calculations. The basis for this assumption is as follows. The repository allotment for DSNF, that also includes naval fuel, is 2,333 MTHM (Dreyfus 1995 [DIRS 104384]; Lytle 1995 [DIRS 104398]). The repository allocation for naval fuel is 65 MTHM, leaving an allotment of 2,268 MTHM for DSNF. The DSNF inventory $\left(2,348\right.$ metric ton of ${ }^{238} \mathrm{U}$ ) excluding the bare fuel inventory (48 metric ton of $\left.{ }^{238} \mathrm{U}\right)$ exceeds the repository allotment for DSNF $(2,348-48=2,300$, which is greater than 2,268). Therefore, using the DSNF radionuclide inventory reported in Source Term Estimates for Spent Nuclear Fuels (DOE 2003 [DIRS 163377]), excluding the bare fuel, produces a conservative DSNF inventory for TSPA-LA.

The nonnaval DSNF inventory of 2,348 metric tons of ${ }^{238} \mathrm{U}$ (DOE 2003 [DIRS 163377]) includes 48 metric tons of ${ }^{238} \mathrm{U}$ of bare fuel assemblies. Bare fuel assemblies do not fit in codisposal waste packages. The remaining nonnaval inventory of 2,300 metric tons of ${ }^{238} \mathrm{U}$ are allocated to the 3,412 codisposal packages. The remaining 7,472 waste packages designated for CSNF are fully allocated to PWR and BWR assemblies and are, therefore, not available for bare fuel.

This analysis distributes the remaining DSNF inventory into codisposal waste packages. TSPA-LA models 11,184 waste packages (see Table 4-2), of which 7,472 are CSNF, 300 are 
naval and 3,412 are codisposal (BSC 2004 [DIRS 169472], Table 11). If the codisposal packages are fully loaded, the DSNF and HLW glass repository allocations of 2,333 and 4,667 MTHM respectively, will be exceeded (Dreyfus 1995 [DIRS 104384]); Lytle 1995 [DIRS 104398]). Although the number of DSNF and HLW canisters implied by the number of codisposal waste packages cannot be emplaced in the repository using the existing limits, including these canisters within the TSPA results in a conservative inventory.

As noted in Section 6.6.2, 38 percent of the DSNF radionuclide inventory (Table 4-8) comes from 0.31 percent of the total DSNF. The report states that 0.31 percent of the mass relied heavily on conservative assumptions to compensate for incomplete information. Uncertainties include those related to burnup, BOL (beginning of life) for the fuel, the BOL concentration in structural materials, the impurities in structural materials, the uncertainties related to methodologies, the statistical uncertainties, as well as measured versus calculated uncertainties. All of these attributes are considered and contribute to an overall uncertainty that is applied to the nominal and bounding inventory. If we can assume that the 99.69 percent of the fuels with sufficient information can represent the 0.31 percent of the fuel with insufficient information, the expected value for the radionuclide inventory (curies) for DSNF is more reasonably 62 percent of the nominal inventory estimated (i.e., 62 percent +62 percent $\times 0.31$ percent $\cong$ 62 percent)(DOE 2003 [DIRS 163377]). This assumption is used in the analysis in Section 6.6.2.

For DSNF, radiological inventories are estimated based on a validated ORIGEN code output (i.e., a fuel template) that was developed for that fuel type (DOE 2003 [DIRS 163377]. Approximately 10 percent of the DSNF inventory uses a template that, although based on another fuel type, shares parameters that dominate the model with respect to generation of radionuclides. For about 0.2 percent of the fuels in the inventory, the burnup information is uncertain because of missing or incomplete BOL (beginning of life) and burnup values. For these fuels, BOL heavy metal is assumed to be two times the EOL (end of life) value, which overestimates the burnup for over 96 percent of the DSNF. This assumption produces a very conservative estimate of the burnup, which results in an increased scaling of the template radionuclide inventories. The remainder of approximately 0.11 percent of the DSNF uses a Worst-Case template that was derived by taking the highest normalized (Ci/MTU) values for each radionuclide from all the available templates. Although such a fuel does not physically exist, this template is used to bound fuel materials in the DSNF inventory for which a template cannot be selected (DOE 2004 [DIRS 169354], p. E-18). There are two reasons for this: the unavailability of a template that adequately models the fuel and the unavailability of sufficient information to identify a proper template. For example, various different fuels and cladding types, in which much of the fuel has been destructively examined, and do not conform to any one template. Thus the radionuclide inventory for these fuel records are estimated using the worstcase template, which maximizes the radionuclide production as a function of burnup and produces a conservative estimate. Since bounding burnup information is not available to support estimation of the inventory, the estimated nominal burnup is used and the bounding value is conservatively assumed to be two times (2×) the nominal (DOE 2003 [DIRS 163377], p. 38). Use of the worst-case template provides a high degree of confidence that, for a given burnup, the resulting radionuclide estimate will bound virtually any fuel's actual radionuclide content (DOE 2003 [DIRS 163377], Section E-3.1). The reported inventory is derived using data that 
has been measured, reported, calculated, and modeled having applied statistical analysis to identify those "most likely," as well as those that are bounding.

\subsection{DOE-OWNED HLW (DHLW)}

It is assumed that radionuclide inventory and waste package data from the Savannah River Site (SRS) and the Hanford site are sufficient to characterize the inventory of HLW glass inventory for TSPA-LA. The SRS data is from Allison (2004 [DIRS 168734], Appendix 1) and the Hanford data is from Hamel (2003 [DIRS 164947]). The basis for this assumption is, although earlier reports such as Inventory Abstraction (BSC 2001 [DIRS 157575]) and Source Terms for HLW Glass Canisters (CRWMS M\&O 2000 [DIRS 151947]) analyzed data from Hanford, SRS, INEEL, and the West Valley Demonstration Project, further analyses showed that the SRS and Hanford glass packages dominated the radionuclide content of the glass inventory. This assumption is used in Section 6.6.3.

As with DSNF and CSNF, assumptions pertaining to the reported inventory are also described here. It is noted that the actual number of canisters to be produced at the SRS and their curie concentrations are dependent on the waste loading achieved and the efficiency of cleaning. It is assumed that the glass compositions and curie content in canisters already produced at the SRS provides a suitable modeling basis for future production of SRS canisters.

It is assumed that waste packages will be fully loaded for TSPA-LA purposes. Note that using the "historic method" for counting MTHM per glass canister (2.3 MTHM per West Valley canister and 0.5 MTHM per DHLW canister) (DOE 1985 [DIRS 103492], Table 1-1), the glass allocation of 4,667 MTHM (Dreyfus 1995 [DIRS 104384]; Lytle 1995 [DIRS 104398]) would equal about 8,329 glass canisters instead of the 16,614 canisters used in TSPA for codisposal. The TSPA was calculated assuming the full 16,614 canisters thus providing an extra margin of conservatism and preventing the underestimation of risk due to HLW glass.

An assumption was made in the absence of confirming data to bound the percent waste loading of future HLW canisters based on Hanford's Waste Treatment and Immobilization Plant (WTP) technology case. Estimating a increase of $7 \mathrm{wt} \%$ in waste loading above that specified for the technology case and applying it to the 100 percent fill scenario yields an uncertainty factor of 1.5, which when applied to the HLW inventory derives a maximum value. Since the technology case will require additional technology development to demonstrate the glass waste form and vitrification technology, it is reasonable to make an assumption to bound the waste for this case. 


\section{SCIENTIFIC ANALYSIS DISCUSSION}

This section presents the results of this analysis. A description of the mathematical operations performed in this analysis is presented in more detail in Appendices I and II, and in Excel tables and graphs on the Appendix III CD. The outputs of this analysis, the initial radionuclide inventories (in grams per radionuclide per waste package) and uncertainty distributions associated with this inventory are presented in Tables 7-1 and 7-2, and DTN: SN0310T0505503.004. The outputs are reasonable compared to the inputs, and the results are suitable for the intended use. The uncertainties are taken into account by consistently using the most conservative approach; the calculations, therefore, yield a conservatively bounding set of results. The directly used inputs to this analysis are listed in Section 4.1. The qualification of unqualified data used as direct input is presented in Appendix IV. The following inputs are used as corroborating information:

1. Support for the claim that Zircaloy is highly corrosion resistant under repository conditions (BSC 2003 [DIRS 168795]). The information from this source is addressed in Appendix I.4.3.

2. Superseded report analyzing radionuclide inventory (BSC 2001 [DIRS 157575]). The information from this source is addressed in Sections 1, 6, 6.6.3, and Appendices I and II for an analysis of neutron-activation products in the crud and BWR or PWR hardware.

3. Initial breach fraction of cladding in CSNF (BSC 2003 [DIRS 162153], p. 38). This information from this source is addressed in Appendix I.4.1.

4. Fast release fraction of ${ }^{99} \mathrm{Tc}$ (BSC 2004 [DIRS 167321], Table 8.1-1). This information from this source is addressed in Appendix I.4.1.

5. No credit was taken for DSNF cladding (BSC 2003 [DIRS 163693], p. 50). This information from this source is addressed in Appendix I.4.1.

6. DSNF degradation rate for LA (BSC 2003 [DIRS 163693], p. 65). This information from this source is addressed in Appendix I.4.2.

7. Information from Source Terms for HLW Glass Canisters (CRWMS M\&O 2000 [DIRS 151947], Tables 6-1 and 6-2) is discussed in Section 6.6.3 and Appendix II.3.

8. Information from Total System Performance Assessment for the Site Recommendation (CRWMS M\&O 2000 [DIRS 153246]) is addressed in Appendix I.4.2.

9. Materials specifications for CSNF assembly hardware, specifically stainless steel components were used from DOE 1987 [DIRS 132333] to corroborate information used by the analysis in Appendix I.4.2.

10. Determination of the Accuracy of Utility Spent-Fuel Burnup Records (EPRI 1999 [DIRS 164649]) provided a corroborative measure of the uncertainty related to 
measured versus calculated values of burnup CSNF. This information can be found in Section 6.6.1.

11. Reactor Record Uncertainty Determination (Massie 2004 [DIRS 170651], Summary Sheet) provides 2004 information pertaining to the percent uncertainty related to measured versus calculated values of burnup of CSNF BWR and PWR assemblies. These data can be found in Section 6.6.1 and Appendix III.

12. Source Term Estimates for DOE Spent Nuclear Fuels (DOE 2004 [DIRS 169354]) Revision 1 is used as corroborative input to provide updated DSNF radionuclide inventory data published January 2004. These data are compared with the DSNF radionuclide inventory data used in this analysis to validate the inputs used and validate the uncertainty factors developed. The data used in this analysis to develop the inventory comes from Revision 0 of the same report (DOE 2003 [DIRS 163377]), published in March 2003. These data can be found in Section 6.6.2 and Appendix III Excel workbook file inv_rev1.xls.

13. 2002 Waste Stream Projection Report (BSC 2003 [DIRS 165990], p.16 and 17) is the source for the definitions of Cases A' to D', an alternative set of methodologies used to develop arrival forecasts. Cases A' to D' were compared to Cases A to C from Waste Packages and Source Terms for the Commercial 1999 Design Basis Waste Streams (CRWMS M\&O 2000 [DIRS 138239]), which is also a source of direct input (Table 4-1). The data are part of the uncertainty associated with arrival forecasts used to develop uncertainty factors for CSNF inventory. These definitions can be found in Table 6-6.

14. An illustration from Waste Form Degradation Process Model Report (CRWMS M\&O 2002 [DIRS 150704], Figure 3.1-1) used to provide an overview of waste package types containing different wastes in the inventory (Figure 6-1).

15. An illustration from Yucca Mountain Science and Engineering Report (DOE 2002 [DIRS 155943], Figure 3-5) is used to provide illustration of some waste package configurations for CSNF, DSNF, naval, and HLW glass. This illustration is shown as Figure 6-2.

16. PWR and BWR Source Term Sensitivity Study (BSC 2004 [DIRS 167058]) is used to corroborate the assumption that the source term values from the Mark B assembly are "representative" and can be applied to other PWR assemblies of different classes and initial uranium loadings by a simple ratio of the initial uranium loading. It is also used to corroborate the assumption that the source term values from the GE 2/3 assembly are "representative" and can be applied to other BWR assemblies of different classes and initial uranium loadings by a simple ratio of the initial uranium loading.

This analysis is a simple mathematical compilation of lists of radionuclide inventory data obtained from documented sources (i.e., addition, subtraction, division, multiplication of existing inventory data). No models have been used in this analysis and no alternative methods other than the one used were evaluated to provide a cumulative radionuclide inventory for TSPA-LA. 
The fact that the sources used as data input provide the most recent data needed and that these data are considered bounding, applying simple mathematical operations on the inventories reported for DSNF, CSNF, and HLW projections were considered the only reasonable method.

Uncertainties applied to data were developed from uncertainties commonly used in the nuclear industry. These uncertainties pertain to errors in records (EPRI 1999 [DIRS 164649]), errors in measured versus calculated data (Hermann and DeHart 1998 [DIRS 106563]; DeHart and Hermann 1996 [DIRS 156084]), uncertainties related to the age and activity levels (burnup) of the waste and age-at-arrival using arrival scenarios. Use of known error or uncertainty factors, calculation of averages, and developing ratios as factors to establish ranges of values, are the methods used in this analysis. Where more recent data has become available, comparisons are identified or plotted, or both, to illustrate the validity of calculated uncertainties or show the more recent data is bounded by that used in this analysis, or both. Referenced documents have applied methodologies to developing uncertainties associated with the radionuclide inventory source terms reported and used in this analysis. No other methods of determining the inventory or developing the uncertainty were considered in this analysis.

The sources of data used in this analysis provide "qualified" input data. Sources where the data require qualification in accordance with BSC procedures, the qualification is documented in Appendix IV of this analysis. This data qualification is intended to provide the desired level of confidence that the data are suitable for their intended use and the intended use is only for this analysis. AP-SIII.9Q, Section 5.2.1-1 states, "The extent to which the data demonstrate the properties of interest shall be addressed. One or more of the following factors shall be used when presenting the case that the data are suitable for intended use:"

- Reliability of data source

- Qualification of personnel or organizations generating the data

- Prior uses of the data

- Availability of corroborating data.

Data from the following sources are qualified for intended use in accordance with the above factors in AP-SIII.9Q and found in the Appendix IV as noted:

IV.1. "Projected Glass Composition and Curie Content of Canisters from the Savannah River Site (U)" (Allison 2004 [DIRS 168734], Appendix 1 (Fowler report, Rev.2)).

IV.2. "Waste Treatment and Immobilization Plant (WTP) High-Level Waste (HLW) Canister Production Estimates to Support Analyses by the Yucca Mountain Project" (Hamel 2003 [DIRS 164947]).

IV.3. Validation of SCALE (SASH2H) Isotopic Predictions for BWR Spent Fuel (Hermann and DeHart 1998 [DIRS 106563]); An Extension of the Validation of SCALE (SASH2H) Isotopic Predictions for PWR Spent Fuel (DeHart and Hermann 1996 [DIRS 156084]). 
IV.4. $\quad$ Source Term Estimates for DOE Spent Nuclear Fuels (DOE 2004 [DIRS 163377]; Source Term Estimates for DOE Spent Nuclear Fuels (DOE 2004 [DIRS 169354]).

For data not derived from external sources, AP-SIII.2Q Qualification of Unqualified Data has been used for data qualification. Inputs qualified in accordance with AP-SIII.2Q require a Data Qualification Plan and use of one or a combination of methods identified in Attachment 3 of AP-SIII.2Q. This plan is provided in Appendix V; the results this data qualification task are presented in Section IV.5. The data to be qualified in accordance with AP-SIII.2Q are from the following reference sources:

IV.5 2002 Waste Stream Projections Report (BSC 2003 [DIRS 165990]). Data Qualification Plan for this source of data is in Appendix V; the signed copy is in the record package for this analysis.

Assumptions have been incorporated into this analysis and are documented in Section 5. An assumption was made in the absence of confirming data to bound the percent waste loading of future HLW canisters based on Hanford's Waste Treatment and Immobilization Plant (WTP) technology case. Estimating an increase of $7 \mathrm{wt} \%$ in waste loading above that specified for the technology case and applying it to the 100 percent fill scenario yields an uncertainty factor of 1.5 , which when applied to the HLW inventory derives a maximum value. Because the technology case will require additional technology development to demonstrate the glass waste form and vitrification technology, it is reasonable to make an assumption to bound the waste for this case.

\subsection{RADIONUCLIDES}

The radionuclides of importance to TSPA-LA dose calculations were assessed in Radionuclide Screening (BSC 2002 [DIRS 160059]). This screening document separately considered both the 10,000 -year regulatory period and the million-year FEIS period. Four release scenarios were considered: (1) the nominal scenario, (2) the human-intrusion scenario, (3) an intrusive igneous event, and (4) an eruptive igneous event. These scenarios result in dose from groundwater and the atmospheric pathways. Table 4-13 shows the radionuclides that contribute to 95 percent of the dose for the different scenarios implemented in the TSPA-LA for the regulatory period of 10,000 years (columns 2 and 4), and those added for the million-year period (columns 3 and 5) (BSC 2002 [DIRS 160059]). Additional radionuclides were included for groundwater protection based U.S. Environmental Protection Agency (EPA) regulations (40 CFR 197.30 [DIRS 165519]) and 10 CFR 63.331 [DIRS 156605]. These standards set limits on: 1) combined activity of ${ }^{226} \mathrm{Ra}$ and ${ }^{228} \mathrm{Ra}$ in groundwater; 2) gross alpha activity (including ${ }^{226} \mathrm{Ra}$ but excluding radon and uranium), and 3 ) dose from combined beta and photon emitting radionuclides in groundwater. ${ }^{226} \mathrm{Ra}$ and ${ }^{228} \mathrm{Ra}$ were added to the inventory for TSPA-LA. Compliance with the gross-alpha regulation requires inclusion of appropriate equilibrium activity contributions for short-lived decay products (BSC 2002 [DIRS 160059], Section 6.6.1). Short-lived decay products can be computed from the activities of their parents so it is not necessary to list or include them in the radionuclide inventory for this analysis (DOE 2002 [DIRS 160059], Section 6.6.1). However, Radionuclide Screening (BSC 2002 [DIRS 160059]) notes that the alpha activities of long-lived decay products that have been screened in, and those of their shortlived daughters are to be counted in the gross-alpha calculation. The third item is concerned 
with dose from contaminated drinking water and because this pathway was included in the initial screening, no additional analysis was needed.

Radionuclide Screening (BSC 2002 [DIRS 160059]) noted that some radionuclides that are precursors of important radionuclides were not identified by the screening analysis as potentially important. Table 4-14 illustrates the systematic examination of the radionuclides screened in according to the 95 percent cutoff and of ${ }^{228} \mathrm{Ra}$ included for groundwater protection standard. Three additional radionuclides were identified for inclusion based either on the daughter product or augmentation of the precursor radionuclide screened in: ${ }^{241} \mathrm{Pu},{ }^{245} \mathrm{Cm}$, and ${ }^{235} \mathrm{U}$ (BSC 2002 [DIRS 160059], Table 12). As a result of this analysis, seven precursors have been added for inclusion in TSPA-LA (Table 6-1).

Table 6-1. Precursors Identified as Significant to the Regulatory Period for TSPA-LA

\begin{tabular}{|l|l|}
\hline \multicolumn{1}{|c|}{ Radionuclide } & \multicolumn{1}{c|}{ Added Precursor } \\
\hline${ }^{241} \mathrm{Am}$ & ${ }^{245} \mathrm{Cm}$ and ${ }^{241} \mathrm{Pu}$ \\
\hline${ }^{231} \mathrm{~Pa}$ & ${ }^{235} \mathrm{U}$ \\
\hline${ }^{226} \mathrm{Ra} \mathrm{a}^{2}$ & ${ }^{230} \mathrm{Th}$ \\
\hline${ }^{228} \mathrm{Ra}$ & ${ }^{232} \mathrm{Th}$ \\
\hline${ }^{232} \mathrm{Th}$ & ${ }^{236} \mathrm{U}$ \\
\hline${ }^{238} \mathrm{U}$ & ${ }^{242} \mathrm{Pu}$ \\
\hline Source: & This table is a compilation of the preceding text. \\
NOTE: & $\begin{array}{l}\text { 228 } \mathrm{Ra} \text { was screened in due to EPA groundwater } \\
\text { protection standard 40 CFR Part 197 [DIRS 165519]. }\end{array}$
\end{tabular}

Table 6-2 includes the 21 radionuclides identified as significant to the regulatory period (20 radionuclides identified in Table 4-13 screened in for dose, plus ${ }^{228} \mathrm{Ra}$ included for groundwater protection), plus seven precursors identified in Table 6-1 as significant to the regulatory period. In addition, four additional radionuclides are included in the inventory and are identified for the FEIS million-year period.

\subsection{WASTES AND WASTE PACKAGES}

Figure 6-1 illustrates the four types of nuclear waste in the waste form inventory to be emplaced in the repository: CSNF, DSNF, DHLW glass, and naval spent nuclear fuel. For the repository layout and thermal calculations, ten waste package configurations were designed to accommodate the waste types listed in Table 4-2. (Configurations $7 \mathrm{a}, 7 \mathrm{~b}$ and $8 \mathrm{a}, 8 \mathrm{~b}$ represent two loadings of two configurations.) Figure 6-2 illustrates some of the waste package configurations.

The CSNF configurations 1 through 5 in Table 4-2 contain the commercial fuel assemblies from PWRs and BWRs loaded with either neutron absorber plates (AP) or control rods (CR) for criticality control. The codisposal configurations $6,7 \mathrm{a}, 8 \mathrm{a}, 7 \mathrm{~b}$, and $8 \mathrm{~b}$ in Table 4-2 hold DSNF and DHLW in various sized canisters within the waste package.

The DSNF inventory analyzed in Section 6.6.2 of this analysis includes all DSNF destined for the repository except for the bare fuel and the naval SNF. Bare fuel is CSNF in the custody of DOE and DHLW is analyzed in Section 6.6.3. 
Naval fuel will be packaged in either short or long canisters (Configurations 9 and 10 in Table 4-2). Naval fuel is a DSNF. It is a robust fuel and is included in the allocation for disposal of DSNF. For TSPA-LA postclosure analysis, the 300 naval packages are treated as CSNF packages. This approximation is justified for the following two reasons: 1) naval fuel is not codisposed with glass; 2) naval fuel is a robust fuel, more robust than CSNF, and much more robust than DSNF as modeled in TSPA (no cladding and/or instantaneous dissolution). Even for scenarios where CSNF cladding is not degraded by events, comparison studies have shown that a CSNF package release bounds a naval package release (BSC 2001 [DIRS 152059], Section 6.1.1).

Table 6-2. Included Radionuclides (32)

\begin{tabular}{|c|c|c|c|c|}
\hline $\begin{array}{l}\text { Radionuclides } \\
\text { Important to Dose }\end{array}$ & $\begin{array}{l}\text { Screened in } \\
\text { for Dose }\end{array}$ & $\begin{array}{l}\text { Precursor Screened } \\
\text { in For Dose }\end{array}$ & $\begin{array}{l}\text { Screened In for } \\
\text { Groundwater } \\
\text { Protection (EPA) }\end{array}$ & $\begin{array}{c}\text { Additional Radionuclides for } \\
\text { the FEIS Million-Year } \\
\text { Calculation }\end{array}$ \\
\hline${ }^{227} \mathrm{Ac}$ & ${ }^{227} \mathrm{Ac}$ & & & \\
\hline${ }^{241} \mathrm{Am}$ & ${ }^{241} \mathrm{Am}$ & & & \\
\hline${ }^{243} \mathrm{Am}$ & ${ }^{243} \mathrm{Am}$ & & & \\
\hline${ }^{14} \mathrm{C}$ & ${ }^{14} \mathrm{C}$ & & & \\
\hline${ }^{36} \mathrm{Cl}$ & & & & ${ }^{36} \mathrm{Cl}$ \\
\hline${ }^{245} \mathrm{Cm}$ & & ${ }^{245} \mathrm{Cm}$ & & \\
\hline${ }^{135} \mathrm{Cs}$ & ${ }^{135} \mathrm{Cs}$ & & & \\
\hline${ }^{137} \mathrm{Cs}$ & ${ }^{137} \mathrm{Cs}$ & & & \\
\hline $129 \mathrm{I}$ & ${ }^{129}$ & & & \\
\hline${ }^{237} \mathrm{~Np}$ & ${ }^{237} \mathrm{~Np}$ & & & \\
\hline${ }^{231} \mathrm{~Pa}$ & ${ }^{231} \mathrm{~Pa}$ & & & \\
\hline${ }^{210} \mathrm{~Pb}$ & & & & ${ }^{210} \mathrm{~Pb}$ \\
\hline${ }^{238} \mathrm{Pu}$ & ${ }^{238} \mathrm{Pu}$ & & & \\
\hline${ }^{239} \mathrm{Pu}$ & ${ }^{239} \mathrm{Pu}$ & & & \\
\hline${ }^{240} \mathrm{Pu}$ & ${ }^{240} \mathrm{Pu}$ & & & \\
\hline${ }^{241} \mathrm{Pu}$ & & ${ }^{241} \mathrm{Pu}$ & & \\
\hline${ }^{242} \mathrm{Pu}$ & & ${ }^{242} \mathrm{Pu}$ & & \\
\hline${ }^{226} \mathrm{Ra}^{\mathrm{b}}$ & ${ }^{226} \mathrm{Ra}^{\mathrm{a}}$ & & & \\
\hline${ }^{228} \mathrm{Ra}^{\mathrm{a}}$ & & & ${ }^{228} \mathrm{Ra}^{\mathrm{b}}$ & \\
\hline${ }^{79} \mathrm{Se}$ & & & & ${ }^{79} \mathrm{Se}$ \\
\hline${ }^{126} \mathrm{Sn}$ & & & & ${ }^{126} \mathrm{Sn}$ \\
\hline${ }^{90} \mathrm{Sr}$ & ${ }^{90} \mathrm{Sr}$ & & & \\
\hline${ }^{99} \mathrm{Tc}$ & ${ }^{99} \mathrm{Tc}$ & & & \\
\hline${ }^{229} \mathrm{Th}$ & ${ }^{229} \mathrm{Th}$ & & & \\
\hline${ }^{230} \mathrm{Th}$ & & ${ }^{230} \mathrm{Th}$ & & \\
\hline${ }^{232} \mathrm{Th}$ & & ${ }^{232} \mathrm{Th}$ & & \\
\hline${ }^{232} U$ & ${ }^{232} U$ & & & \\
\hline${ }^{233} \mathrm{U}$ & ${ }^{233} \mathrm{U}$ & & & \\
\hline${ }^{234} \mathrm{U}$ & ${ }^{234} \mathrm{U}$ & & & \\
\hline${ }^{235} \mathrm{U}$ & & ${ }^{235} \mathrm{U}$ & & \\
\hline${ }^{236} U$ & & ${ }^{236} \mathrm{U}$ & & \\
\hline${ }^{238} \mathrm{U}$ & ${ }^{238} \mathrm{U}$ & & & \\
\hline count & 20 & 7 & 1 & 4 \\
\hline
\end{tabular}

Source: BSC 2002 [DIRS 160059], Section 6.1.

NOTES: Radionuclide Screening (BSC [DIRS 160059]) shows that extending screening to 20,000 years after emplacement adds no new radionuclides.

a Additional Isotopes required by 10 CFR 63.331b [DIRS 156605] for groundwater protection.

b Additional Isotopes required by EPA 40 CFR 197.30a [DIRS 165519] for groundwater protection. 


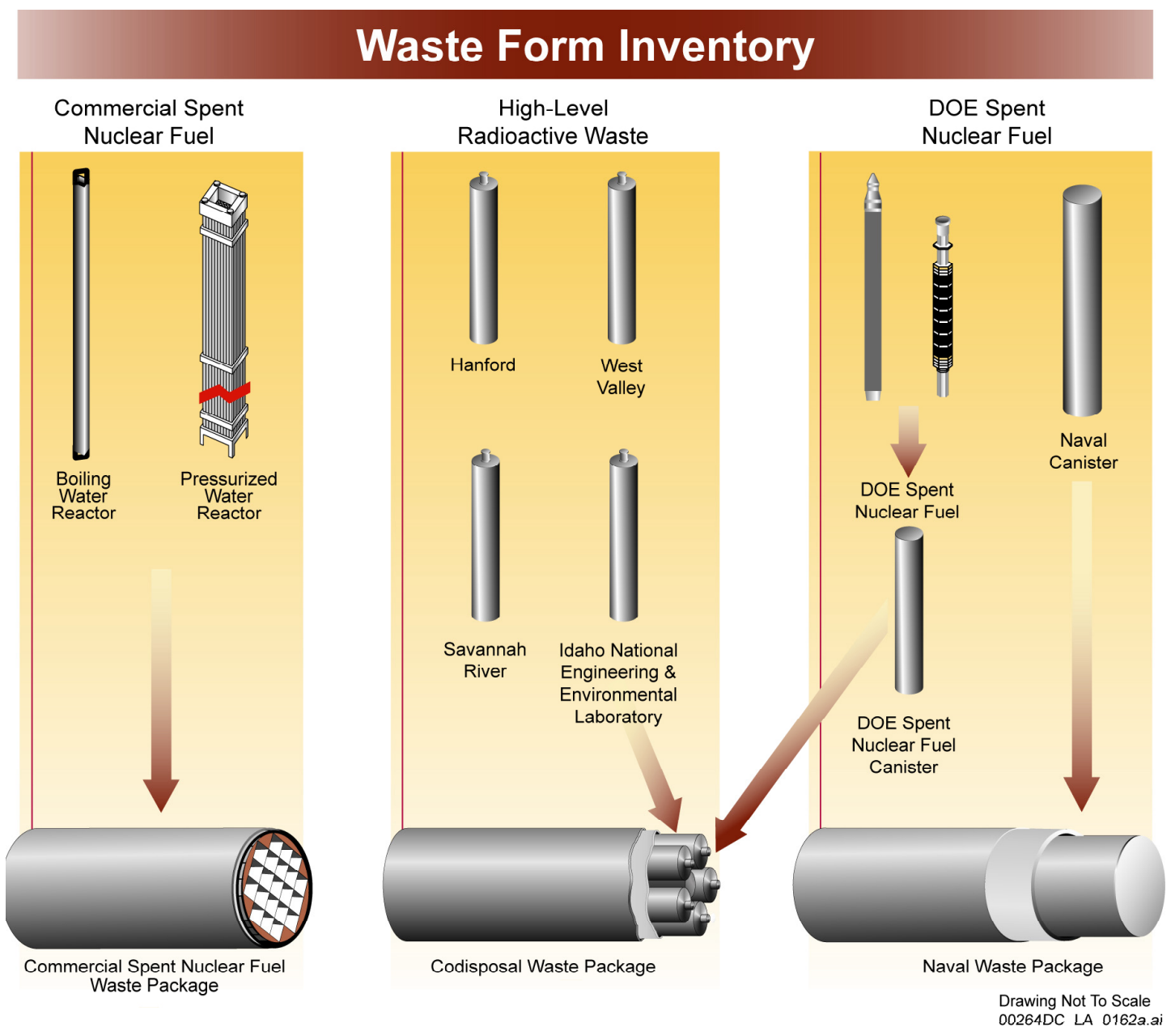

Source: Modified from CRWMS M\&O 2000 [DIRS 150707], Figure 3.1-1.

Figure 6-1. Various Waste Package Types Containing Different Wastes

There are many types of DOE-owned fuel assemblies and parts. These fuels and parts come from a wide range of reactor types with various cladding materials and enrichments. The large number of DSNFs is indicative of the number and variety of different reactor types that once existed. The DOE-owned fuel assemblies and parts have been categorized by the size, shape, composition, condition of the assemblies, and the size and corrosion resistance of the canister into which wastes are to be loaded (DOE 2003 [DIRS 163377]):

- Short standard canister, $1.5 \mathrm{ft}$ by $10 \mathrm{ft}$

- Long standard canister, $1.5 \mathrm{ft}$ by $15 \mathrm{ft}$

- Wide short standard canister, $2 \mathrm{ft}$ by $10 \mathrm{ft}$

- Wide long standard canister, $2 \mathrm{ft}$ by $15 \mathrm{ft}$

- High-integrity can (HIC) (placed within a long standard canister), $1.5 \mathrm{ft}$ by $15 \mathrm{ft}$

- Multicanister overpacks (MCO), $2.1 \mathrm{ft}$ by $14 \mathrm{ft}$

- Bare PWR and BWR assemblies. 

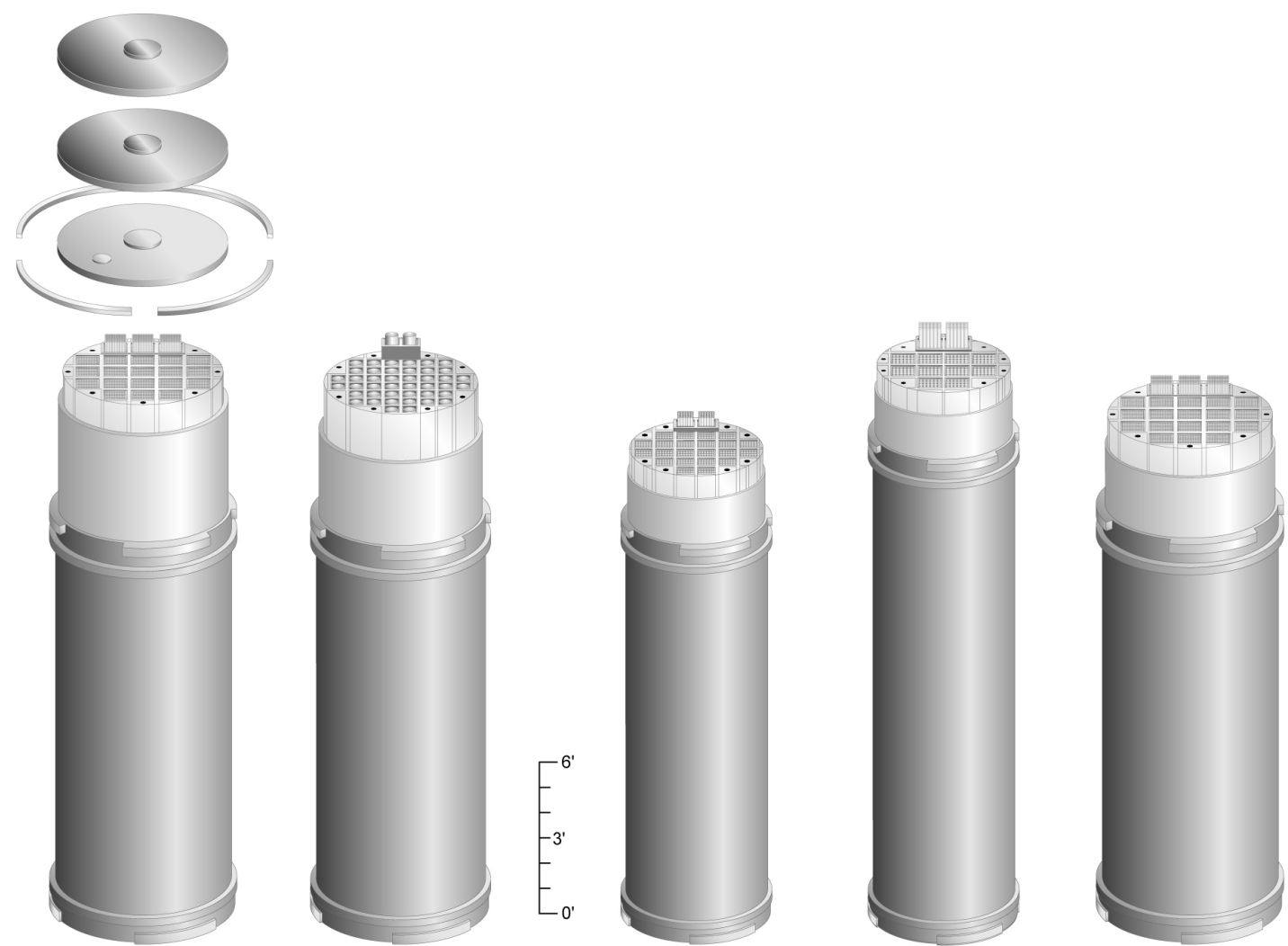

21-PWRCR

44-BWR

24-BWR

12-PWR

21-PWRAP
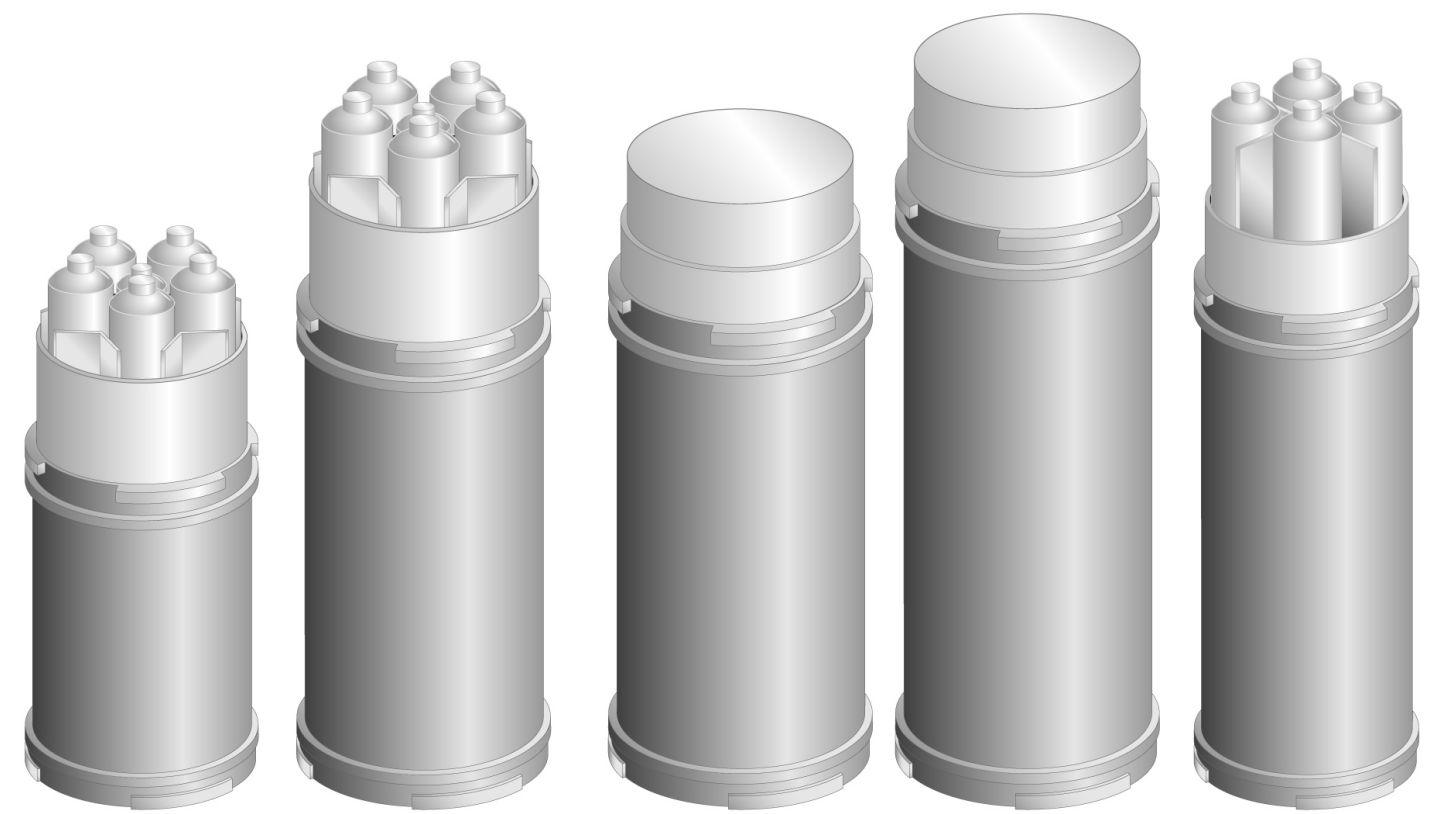

5-DHLW/DOE SNF Short

\section{5-DHLW/DOE}

SNF Long
Naval SNF Long

Source: Modified from DOE 2002 [DIRS 155943], Figure 3-5.

NOTE: For clarity, basket is excluded from this illustration.

Figure 6-2. Some Waste Package Configurations for CSNF, DSNF, Naval, and HLW Glass 
The wide canisters and the bare PWR and BWR assemblies from DOE (DOE 2003 [DIRS 163377]) are not mentioned in Table 4-2. The DOE has possession of 79 PWR and 87 BWR assemblies, which would fit into four 21-PWR packages and two 44-BWR packages. This trivial number of packages, compared to the number of other CSNF packages, is not included in the DSNF average for TSPA-LA. The wide packages, however, are included in TSPA-LA, as shown in the alternate set of loadings in Table 6-3.

During production of this analysis, the codisposal loadings changed from those in Table 4-2 to those in Table 6-3. In Table 6-3, the CDSP configurations have been altered to accept the DSNF inventory that represents 2,300 metric tons of ${ }^{238} \mathrm{U}$ (DOE 2003 [DIRS 163377]), while preserving the total number of codisposal packages (DOE 2003 [DIRS 167367]. DSNF data on nominal and bounding fuel inventories in total curies per category and the number of packages per category are shown in Tables 4-8 and 4-9 (DOE 2003 [DIRS 163377], "Total 2030 D568_585.xls"). These data were used to develop the data for the DOE canister configurations in Table 6-3. The numbers of packages needed to accommodate the canisters in each category were identified. One canister per package was calculated for each configuration except multi-canister overpack (MCO), which has two canisters per package. Unneeded radionuclides were removed from this data and these data were placed in DSNF Ci Summary 32 (Appendix III Microsoft Excel workbook: inv_rev1.xls, worksheet: Ci summary 32 for DSNF). The detailed process for calculating the old and new average inventory per package is shown in Appendix II-3.

The largest difference between Tables 4-2 and 6-3 is the redefinition of Configuration $8 \mathrm{a}$ to accommodate the wide canisters within waste packages designed to hold the multicanisteroverpack-type (MCO) canisters. Configuration 8a has 192 canisters to accommodate the 165 wide-short and 27 wide-long canisters (DOE 2003 [DIRS 163377]). Configuration 7a has both long and high-integrity cans (HIC) in long-standard canisters. Configuration $7 \mathrm{~b}$ has the seven waste packages without DSNF needed to match the total number of codisposal packages listed in Table 4-2. Note the move of glass canisters from Configuration $7 \mathrm{~b}$ to the other configurations. The new configurations accommodate 195 more DSNF canisters and 543 fewer glass canisters. The deviation of Table 6-3 from Table 4-2 is justified, because Table 4-2 was provided for layout and thermal purposes and the codisposal packages represent a small fraction of the thermal load. In addition, during the preparation of this analysis, the maximum capacity/loading of CDSP waste packages (as well as CSNF) was documented as one of the functional and operational requirements and design solutions (DOE 2003 [DIRS 163377]).

Figure 6-3 plots the number of waste packages of each type for the two alternate configurations. It can be seen that the CSNF configurations dominate the co-disposal and naval configurations. 
Table 6-3. Package Configurations Including New Waste Codisposal Packages to Accommodate DSNF

\begin{tabular}{|c|c|c|c|c|c|c|c|}
\hline $\begin{array}{c}\text { Configuration } \\
\text { Number }\end{array}$ & $\begin{array}{c}\text { Waste } \\
\text { Package } \\
\text { Type }\end{array}$ & $\begin{array}{c}\text { Number of } \\
\text { Waste } \\
\text { Packages }\end{array}$ & $\begin{array}{l}\text { Spent Nuclear } \\
\text { Fuel Unit }\end{array}$ & $\begin{array}{l}\text { Max \# of } \\
\text { Units per } \\
\text { Package }^{a}\end{array}$ & $\begin{array}{c}\text { \# of Glass } \\
\text { Canisters } \\
\text { per } \\
\text { Package }^{\text {a }}\end{array}$ & $\begin{array}{l}\text { Glass } \\
\text { Unit }\end{array}$ & Shorthand \\
\hline 1 & CSNF & 4,299 & PWR assembly & 21 & 0 & & 21-PWR AP \\
\hline 2 & CSNF & 95 & PWR assembly & 21 & 0 & & 21-PWR CR \\
\hline 3 & CSNF & 163 & PWR assembly & 12 & 0 & & 12-PWR AP \\
\hline 4 & CSNF & 2,831 & BWR assembly & 44 & 0 & & 44-BWR \\
\hline 5 & CSNF & 84 & BWR assembly & 24 & 0 & & 24-BWR \\
\hline 6 & Codisposal & 1,403 & Short Canister & $1 \mathrm{DSNF}$ & $5 \mathrm{HLW}$ & short & $1 \mathrm{~S} / 5 \mathrm{~S}$ \\
\hline $7 a$ & Codisposal & 1,608 & Long Canister & $1 \mathrm{DSNF}$ & $5 \mathrm{HLW}$ & long & $1 \mathrm{~L} / 5 \mathrm{~L}$ \\
\hline $8 a$ & Codisposal & 192 & Wide Canister & 1 DSNF & $3 \mathrm{HLW}$ & long & $1 \mathrm{~W} / 3 \mathrm{~L}$ \\
\hline $7 b$ & Codisposal & 7 & None & 0 & $5 \mathrm{HLW}$ & long & $0 / 5 \mathrm{~L}$ \\
\hline $8 \mathrm{~b}$ & Codisposal & 202 & $\mathrm{MCO}$ & $2 \mathrm{MCO}$ & $2 \mathrm{HLW}$ & long & $2 \mathrm{MCO} / 2 \mathrm{~L}$ \\
\hline 9 & Naval & 144 & Canister & 1 & 0 & & Naval \\
\hline 10 & Naval & 156 & Canister & 1 & 0 & & Naval \\
\hline \multicolumn{2}{|c|}{$\begin{array}{c}\text { Total Number of Codisposal } \\
\text { Waste Packages }\end{array}$} & 3,412 & & & & & \\
\hline \multicolumn{2}{|c|}{$\begin{array}{c}\text { Total Number of CSNF + Naval } \\
\text { Waste Packages }\end{array}$} & 7,772 & & & & & \\
\hline \multicolumn{2}{|c|}{ Grand Total } & 11,184 & & & & & \\
\hline
\end{tabular}

Source: DOE 2003 [DIRS 163377], “Total 2030 D568--585.xls”. From Appendix III Microsoft Excel workbook: inv_rev1.xls, worksheet: new configs.

NOTES: The CSNF assemblies in DOE custody (bare fuel) were not included in the DSNF inventory for TSPA-LA. See DSNF Assumptions, Sec. 5.2.

a Maximum capacity for CDSP, naval, MCO, and BWR/PWR CSNF waste packages are defined in DOE 2003 [DIRS 167367]. 


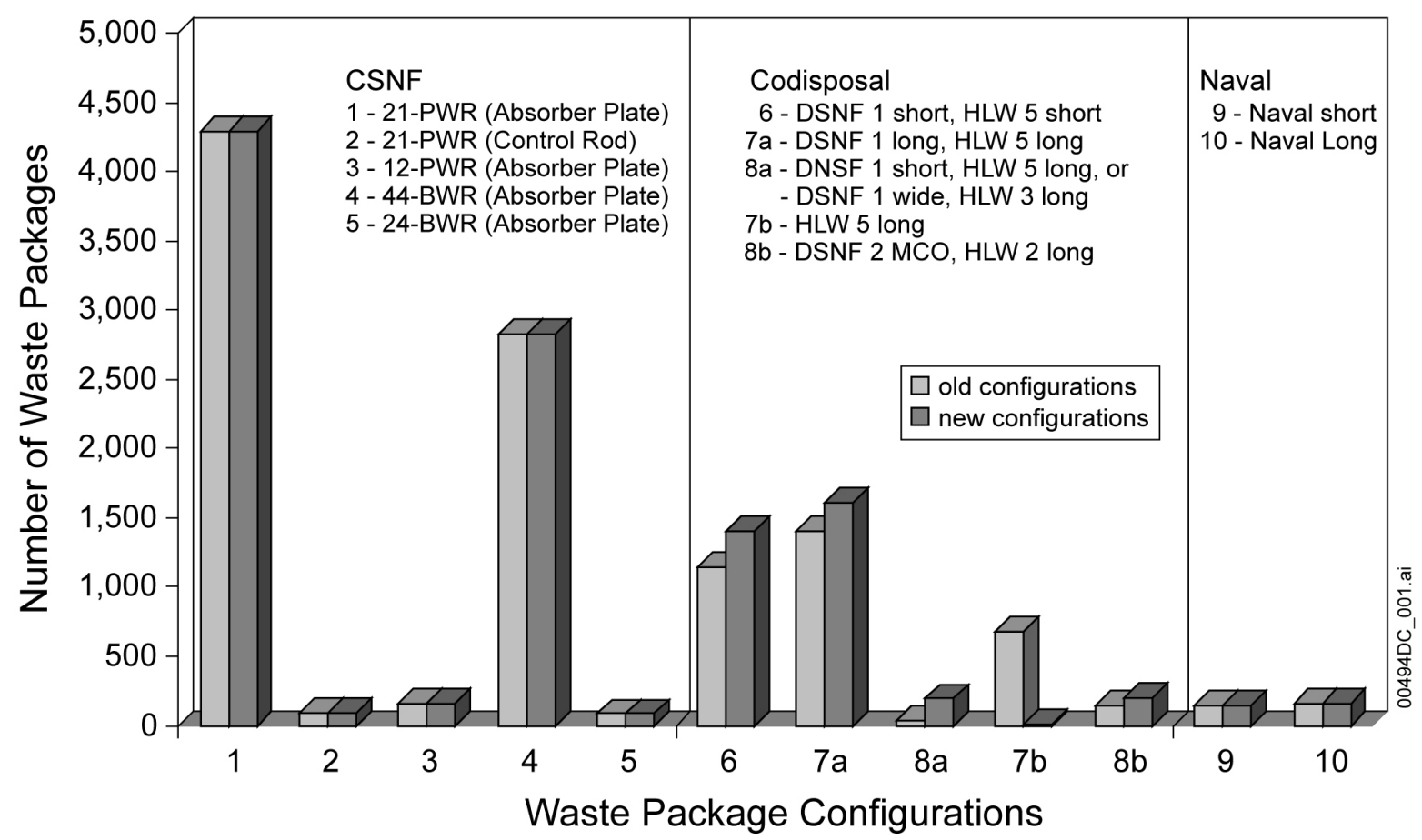

Source: From Appendix III: Microsoft Excel workbook: inv_rev1.xls, worksheet "chart config."

Figure 6-3. Histograms of Waste Package Configurations

DHLW glass will be delivered to the repository in short and long canisters.

\subsection{FEATURES, EVENTS, AND PROCESSES CONSIDERED IN THE ANALYSIS}

As stipulated in Technical Work Plan For: Regulatory Integration Modeling and Analysis of the Waste Form and Waste Package (BSC 2004 [DIRS 171583]), this analysis addresses key radionuclide inventory-related features, events, and processes (FEPs) for waste form and engineered barrier system components of the repository that are screened in (i.e., included FEPs) for TSPA-LA. These FEPs are identified in Table 6-4. There were no "screened-out" FEPs identified.

Each FEP was evaluated for inclusion or exclusion in the total system performance assessment against three criteria, which are stated as regulatory requirements at NRC's rule 10 CFR 63.114(d)(e)(f) [DIRS 156605]. The development of a comprehensive list of FEPs potentially relevant to postclosure performance of the potential Yucca Mountain repository is an ongoing, iterative process based on site-specific information, design, and regulations. The approach for developing an initial list of FEPs, in support of TSPA-SR (CRWMS M\&O 2000 [DIRS 153246]), was documented in The Development of Information Catalogued in REV00 of the YMP FEP Database (BSC 2001 [DIRS 154365]). The initial FEP list contained 328 FEPs, of which 176 were included in TSPA-SR models (CRWMS M\&O 2000 [DIRS 153246], Tables B-9 through B-17). To support TSPA-LA, the FEP list was reevaluated in accordance with The Enhanced Plan for Features, Events, and Processes (FEPs) at Yucca Mountain (BSC 2002 [DIRS 158966]). 
Table 6-4 provides a list of FEPs that are evaluated in this analysis in accordance with their assignment in the LA FEP list (MO0407SEPFEPLA.000 [DIRS 170760]). Specific reference to the various sections within this document where issues related to each FEP are addressed is provided in the tables. The detailed discussion of these FEPs, their implementation in TSPA-LA, and the exclusionary arguments are documented in Miscellaneous Waste-Form FEPS (BSC 2004 [DIRS 170020]).

Table 6-4. Features, Events, and Processes Included (Screened In) in TSPA-LA and Addressed in this Report

\begin{tabular}{|l|l|l|}
\hline \multicolumn{1}{|c|}{ FEP Number } & \multicolumn{1}{|c|}{ FEP Name } & Sections Where Disposition is Described \\
\hline 2.1.01.01.0A & Waste inventory & $\begin{array}{l}\text { All, summarized in Section } 6.7 \\
\text { Radionuclide Screening (BSC 2002 [DIRS } \\
160059], \text { Tables 12 and 13) }\end{array}$ \\
\hline 2.1.01.03.0A & Heterogeneity of waste inventory & Sections 6.4 and 6.6 \\
\hline $3.1 .01 .01 .0 \mathrm{~A}$ & Radioactive decay and in-growth & Section 6.1 \\
\hline
\end{tabular}

Source: DTN: MO0407SEPFEPLA6.000 [DIRS 170760].

\subsection{APPROACH AND METHODS OF CALCULATIONS}

\subsubsection{Radionuclide Inventory}

All direct inputs are listed in Table 4-1. The inputs identified in Table 4-1 and the new configurations defined in Table 6-3 were used to calculate the nominal radionuclide inventory in grams per package for representative CSNF and codisposal waste packages. The inventories and associated uncertainty ranges were calculated using standard functions of the Microsoft Excel Software. These calculations and electronic data files are described in Appendix II. The data are developed and illustrated in Appendix III that is a CD containing Microsoft Excel workbook: inv_rev1.xls. These calculations resulted from inventories identified for the year of projected completion of emplacement (e.g., 2033 for CSNF and 2030 for HLW and DSNF). TSPA-LA requires inventory for the year of repository closure and, therefore, takes the output of this analysis and decays the inventory to that date, which is 2060 for the TSPA-LA calculations. This report provides the inventories at years 2030 and 2033. Further discussion of the calculations supporting the uncertainty ranges is provided in Section 6.6.

\subsubsection{Inventory Heterogeneity}

The repository waste types are heterogeneous both in type (SNF versus glass) and in inventory per package. CSNF, DSNF, and HLW shipped to the repository will contain quantities of radionuclides that vary from waste package to waste package, fuel assembly to fuel assembly, and from canister to canister. The composition of each of these waste forms vary due to several factors that include but are not limited to initial uranium enrichment, possible plutonium enrichment, and fuel burn up. Given these differences in composition, the mass of radionuclides available for transport will vary significantly among waste packages. The heterogeneity is larger for DSNF and HLW glass inventories than for CSNF. This package-to-package inventory variability is not significant for postclosure TSPA-LA because it samples across many realizations, and each waste package is as likely to fail as any other one. The heterogeneity of the 
inventory for TSPA-LA postclosure performance is characterized with the uncertainty parameters (Section 6.6) for the average inventory within the CSNF and codisposal packages.

\subsubsection{Radionuclide Analysis of Activated Mineral Deposits on Assemblies}

Appendix I is an analysis of the radionuclides that exist on the outside of cladding and the assembly hardware. This analysis demonstrates that it is appropriate to neglect the radionuclide contribution from activated mineral deposits (crud) on CSNF assemblies in TSPA-LA. However, the Appendix I analysis identifies ${ }^{99} \mathrm{Tc}$ and ${ }^{14} \mathrm{C}$ as potentially significant hardwareactivation products in CSNF assemblies. As demonstrated in the analysis, a negligible fraction of the ${ }^{99} \mathrm{Tc}$ in CSNF is due to hardware activation. Because the TSPA does not take credit for DSNF cladding, the ${ }^{99} \mathrm{Tc}$ inventory from CSNF hardware is overwhelmed by the ${ }^{99} \mathrm{Tc}$ from DSNF in codisposal waste packages. Therefore, combining the inventory of ${ }^{99} \mathrm{Tc}$ from CSNF hardware-activation products together with the ${ }^{99} \mathrm{Tc}$ in the CSNF matrix, as has been done in the supporting calculations of Radionuclide Screening (BSC 2002 [DIRS 160059]), is an acceptable approximation for TSPA-LA. The analysis in Appendix I estimates that approximately 18 percent of the ${ }^{14} \mathrm{C}$ inventory in CSNF originates from neutron activation of stainless steel hardware outside the fuel rods. This hardware will start to corrode and release ${ }^{14} \mathrm{C}$ upon waste package breach. TSPA-LA will consider this contribution separately from the ${ }^{14} \mathrm{C}$ in the fuel matrix.

\subsection{RADIONUCLIDE INVENTORY ANALYSES RESULTS}

Table 7-1 shows the expected nominal inventory in average grams per package for 32 radionuclides for each waste type at year 2030 or 2033. The inventory is shown in Figure 6-4 with the radionuclides listed in descending order of the mass in the CSNF packages. The numerical values are provided in Appendix III Microsoft Excel workbook: inv_rev1.xls, worksheet Chart gpp. Uncertainty in the inventory values is discussed in the next section.

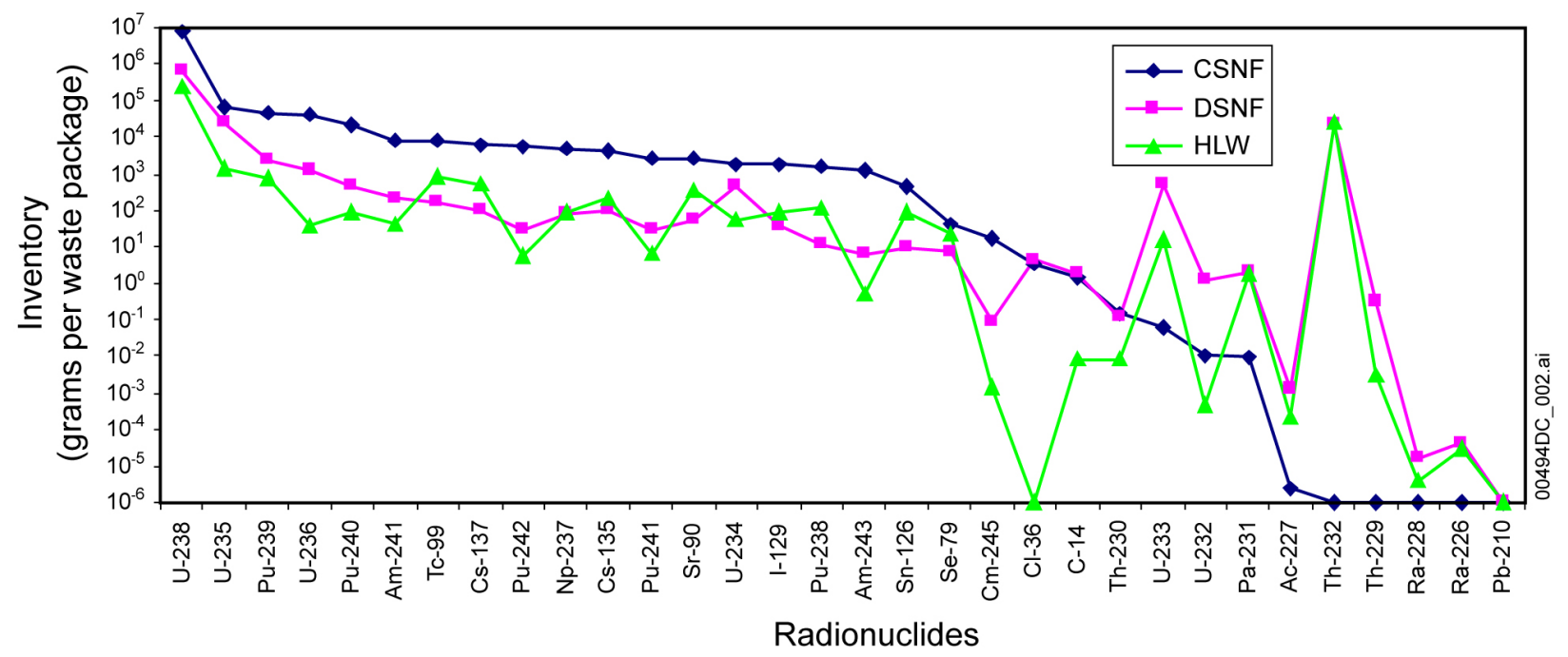

Source: From Appendix III Microsoft Excel workbook: inv_rev1.xls, worksheet Chart gpp.

NOTE: Years of Projection: CSNF, 2033; DSNF, 2030; and HLW, 2030.

Figure 6-4. Average Grams per Package of Radionuclides for Each Waste Type 


\subsection{DISCUSSION OF UNCERTAINTIES}

A number of sources contribute to the uncertainty in the radionuclide inventories. The first source is due to the computational method and nuclear data used in predicting future radionuclide inventories (e.g., isotopic neutron cross section or decay half-life). The second source of uncertainty is the completeness of the records that are kept for the SNF and HLW materials (e.g., burnup history or HLW batch compositions). The third source, and most difficult to quantify, is the uncertainty about future decisions that will influence the creation, packaging and shipment of waste. These decisions influence the selection of waste types destined for emplacement for which the "legal limit" is defined as 70,000 MTHM. Because the waste is heterogeneous, the selection process can change the average waste characteristics. Uncertainty is discussed in greater detail in the following subsections for each of the three waste types.

\subsubsection{CSNF Waste}

The investigations of computational methods for the prediction of radionuclide inventory based on uncertainties in PWR and BWR burnup data have been reviewed. It has been shown that isotopic concentrations can be predicted with "reasonable accuracy" relative to measured data even in light of the complexities of BWR and PWR reactor design and operation. Records and nuclear data associated with burnup and nuclear reactor operation have been studied by DeHart and Hermann (1996 [DIRS 156084]) and Hermann and DeHart (1998 [DIRS 106563]). Validation studies have demonstrated the capability to predict the isotopic composition of PWR and BWR fuels as a function of burnup history using the computer code systems SCALE (Standardized Computer Analysis for Licensing Evaluation) and SASH2H, a multicode sequence that determines the isotopic composition of spent fuel using the ORIGEN-S code for depletion and decay calculations (DeHart and Hermann 1996 [DIRS 156084], p.1); Hermann and DeHart (1998 [DIRS 106563], p. xi).

Differences between calculated and measured isotopic concentrations for any fuel result from biases and uncertainties in both the calculational method and the original experimental measurement. The uncertainty associated with the prediction of the concentration of a given isotope is estimated from a set of measured-to-calculated ratios. The reported average percentage difference between measured and computed isotopic concentrations are used in this analysis to evaluate the uncertainty associated with the CSNF radionuclide inventory. Uncertainties for other radionuclides of interest to TSPA-LA that are not part of nuclear reactor operations are evaluated by these methods as well in the absence of data specific to such isotopes. Table 4-7 lists the "average percent difference between measured and computed isotopic concentrations" for those isotopes important to dose for 10,000-year regulatory period using Equation 6-1 as calculated by DeHart and Hermann (1996 [DIRS 156084], Table 19) and Hermann and DeHart (1998 [DIRS 106563], Table 24). The sources studied BWR and PWR fuels respectively.

$$
\% \text { Difference }=(\text { calculated } / \text { measured }-1) \times 100 \%
$$

The maximum and minimum percent difference between measured and computed isotopic concentrations for specific isotopes shown in Table 4-7 is +12.1 percent for ${ }^{99} \mathrm{Tc}$ and -7 percent for ${ }^{238} \mathrm{Pu}$. This percent difference is used to develop correction factors for CSNF in this analysis. The values ( +12.1 percent and -7 percent) have been converted to correction factors of 0.89 and 
1.08, respectively using Equation 6-2 and have been applied to the CSNF inventory (Section 6.6.1). Qualification of data used as direct input to this analysis taken from DeHart and Hermann (1996 [DIRS 156084], Table 19) and Hermann and DeHart (1998 [DIRS 106563], Table 24) is provided in Appendix IV.3.

$$
\text { Correction factor }=1 /[1+(\text { measure of error/100) }]
$$

The use of burnup uncertainty for PWR and BWR fuel is well known in the nuclear industry. Utility data were used to evaluate the uncertainties associated with calculated burnup versus measured burnup, and the percent difference of calculated to measured burnup $(P)$. Data for 5,447 fuel assemblies at the end of cycle (EOC) in groupings of burnup: $>10,000,10,000$ to 30,000 , and burnup $>30,000 \mathrm{MWd} / \mathrm{MTU}$ were evaluated and recently reported (Massie 2004 [DIRS 170651], Summary Sheet). $(P)$ is defined in Massie (2004 [DIRS 170651]) as the "percent difference of calculated to measured burnup" as shown by the Equation 6-3. It was determined that the largest uncertainty associated with $P$ for BWR and PWR assemblies, was 4.2 percent.

$$
P=100 \text { (calculated burnup - measured burnup)/(measured burnup) }
$$

Determination of the Accuracy of Utility Spent-Fuel Burnup Records (EPRI 1999 [DIRS 164649] p. vii) estimates the uncertainty in burnup history records to be 1.89 percent. Burnup history and uncertainties related to computational methods, records, and nuclear data were applied in the inventory calculations by DeHart and Hermann (1996 [DIRS 156084]) and Hermann and DeHart (1998 [DIRS 106563]). Therefore, these factors need not be applied separately in this analysis of DSNF radionuclide uncertainty.

The heterogeneity in CSNF inventory can be seen in the difference between configurations as shown in Figure 6-5, which compares the average grams per package for the 32 radionuclides of importance to the TSPA-LA for five CSNF configurations. The ratio of configuration average inventory to the repository weighted average inventory for each radionuclide is shown in Figure 6-6. In Figures 6-5 and 6-6, Configurations 1 (21-PWR AP), 3 (12-PWR AP), and 4 (44-BWR) are clustered around the weighted average. Configurations 2 (21-PWR CR) and 5 (24-BWR) are lower for all but ${ }^{14} \mathrm{C},{ }^{230} \mathrm{Th}$, and ${ }^{235} \mathrm{U}$. The maximum ratio of an isotopeaveraged grams per package, to the weighted average for a CSNF configuration is 1.3, with a minimum of 0.15. Calculations are shown in Appendix III Microsoft Excel workbook: inv_rev1.xls, worksheet config variability.

The configuration inventory trends are consistent with the average burnup trends shown in Table 6-5. Note that the correlation of radionuclide inventory with burnup is strong for activation and fission products, but weak for ${ }^{238} \mathrm{U} .{ }^{238} \mathrm{U}$ does not decrease much during reactor operations even with enrichments of 5 percent and maximum burnup as can be seen in the tight cluster of ${ }^{238} U$ inventories in Figures 6-5 and 6-6. The range of ${ }^{238} U$ inventory in Figures 6-5 and 6-6 is dominated by the variation in the amount of fuel per package in each configuration. 


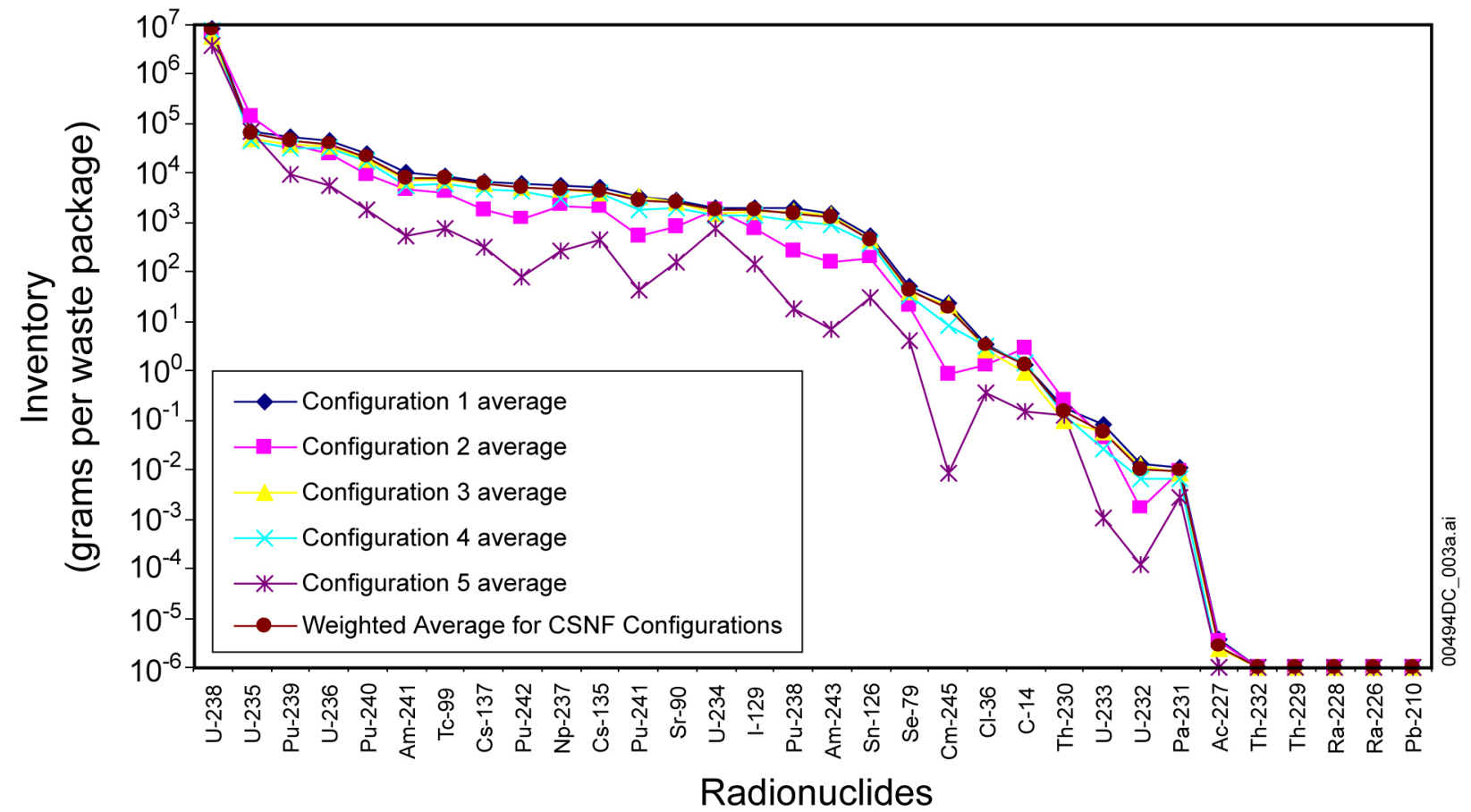

Source: From Appendix III Microsoft Excel workbook: inv_rev1.xls, worksheet, NewSRSbatches .

Figure 6-5. Comparison of the Per-Package Inventories of the Five CSNF Configurations

Table 6-5. Average Burnups for the 5 CSNF Configurations, and Ratios to Average

\begin{tabular}{|c|c|c|c|c|}
\hline Configuration & Number of Packages & $\begin{array}{c}\text { Average } \\
\text { Burnup } \\
\text { (GWd/MTU) }\end{array}$ & Configuration & $\begin{array}{c}\text { Ratio: Average } \\
\text { Burnup/Weighted } \\
\text { average }\end{array}$ \\
\hline 1 & 4,299 & 41 & 1 & 1.09 \\
\hline 2 & 95 & 20 & 2 & 0.51 \\
\hline 3 & 163 & 46 & 3 & 1.21 \\
\hline 4 & 2,831 & 34 & 4 & 0.89 \\
\hline 5 & 84 & 8 & 5 & 0.21 \\
\hline Total & 7,472 & & & \\
\hline $\begin{array}{c}\text { Weighted } \\
\text { Average }\end{array}$ & & & & \\
\hline Minimum & & 38 & & \\
\hline Maximum & & & & \\
\hline
\end{tabular}

Source: CRWMS M\&O 2000 [DIRS 138239]. See (this analysis) input data in Table 4-5 and Appendix III Microsoft Excel workbook: inv_rev1.xls, worksheet burnup. 


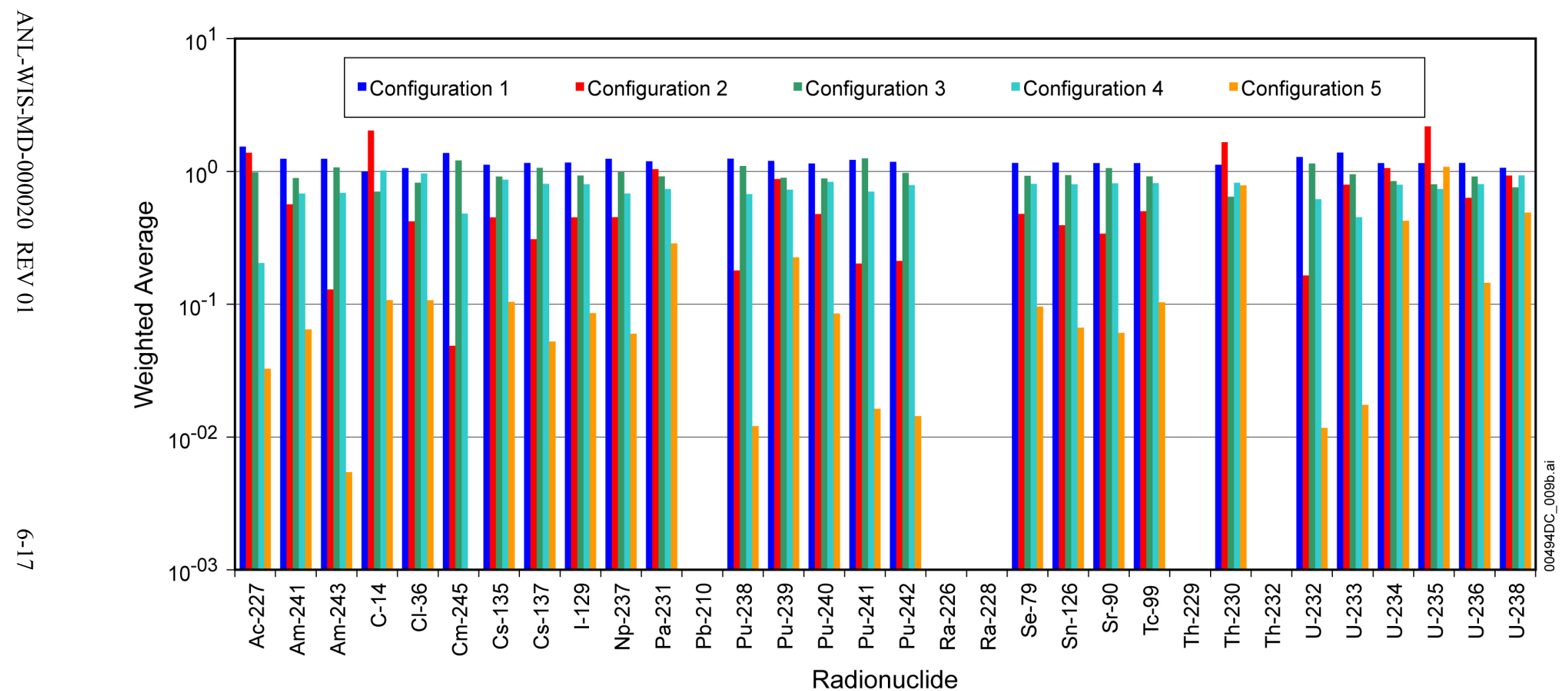

Source: Appendix III Microsoft Excel workbook: inv rev1.xls, worksheet config variability.

NOTE: The weighted average is the grams per waste package divided by the weighted average grams per waste package.

Figure 6-6. Ratios of CSNF Configuration Inventories to the CSNF Weighted Average 
To investigate the uncertainty in the repository-average inventories due to heterogeneity of the waste, the average burnups from three 1999 arrival forecasts, A to C (CRWMS M\&O 2000 [DIRS 138239]) and four 2002 arrival forecasts, $A^{\prime}$ to $D^{\prime}$ (BSC 2003 [DIRS 165990], Section 3.2.1) were compared. The "base case" (i.e., Case A 63,000 MTHM) (CRWMS M\&O 2000 [DIRS 138239]), was used to derive the CSNF inventory given in Table 7-1. Since it is unknown which assemblies the utilities will send at a given time, factors were calculated using the three 1999 arrival forecasts in relation to the four 2002 forecasts, all based on the base case of 63,000 MTHM commercial fuel allocation. For ease of comparison, the cases are defined in Table 6-6.

Table 6-6. Arrival Forecasts for the 63,000 MTU

\begin{tabular}{|c|l|}
\hline Case & \multicolumn{1}{c|}{ Definition } \\
\hline A & Fuel selection begins with 10-year-old spent fuel \\
\hline B & Fuel selection begins with 10-year-old spent fuel in strict order of age \\
\hline C & Fuel selection begins with oldest fuel first. \\
\hline$A^{\prime}$ & Oldest fuel first with no dry storage.(OFF) \\
\hline B' $^{\prime}$ & Youngest fuel first greater than 10 years (YFF10) \\
\hline C' $^{\prime}$ & Youngest Fuel first greater that 5 years old in strict age order (YFF5) \\
\hline$D^{\prime}$ & $\begin{array}{l}\text { Limiting YFF5: All youngest (5-year old) fuel is selected first followed by older fuel } \\
\text { in increasing age order. }\end{array}$ \\
\hline \multirow{2}{*}{ Source: } & $\begin{array}{l}\text { Cases A to C are from CRWMS M\&O 2000 [DIRS 138239], Tables 10, 12, and 14 } \\
\text { Cases A' to D' are from BSC 2003 [DIRS 165990]. }\end{array}$
\end{tabular}

The actual arrival sequence will be determined by the utilities, but the forecasts were designed to bound the actual arrival sequence with waste streams that are the most and least stressing to the repository systems. The 2002 forecast arrival scenarios B', C', and D' have larger fractions of younger fuel than the 1999 forecast projections. The resulting higher average burnups for these scenarios can be seen in Table 6-7. Because reactor technology has advanced and the younger fuels have higher average burnups than older fuels, the average burnups from these arrival scenarios are higher. The minimum and maximum projected average burnup ratios for these, and all the cases over the 1999 Case A, are 0.95 and 1.29 (Table 6-7). When multiplied by the minimum and maximum correction factors (measured/calculated), of 0.89 and 1.08 for the computational method, a range of 0.85 to 1.40 was obtained. This range of ratios provides a reasonable estimate for the range of uncertainty present in the repository-average inventories for burnup-dependent radionuclides. Since the radionuclide inventories are burnup-dependent (except that of ${ }^{238} \mathrm{U}$ for CSNF), they were not sampled independently. Accordingly, a single variable is defined to capture the uncertainty for all isotopes except ${ }^{238} \mathrm{U}$. In this case, an uncertainty multiplier was chosen that was sampled and then applied to all radionuclide inventories except ${ }^{238} \mathrm{U}$. In defining the probability distribution of this multiplier, the end points were known (i.e., 0.85 and 1.40), but the shape of the uncertainty distribution was unknown. In the absence of that information, a uniform distribution was chosen. Thus, an uncertainty multiplier with a uniform distribution between 0.85 and 1.40 was chosen for the TSPA-LA, for application to the nominal CSNF values (provided in Table 7-1) for all radionuclides except ${ }^{238} \mathrm{U}$. 
Table 6-7. Average Burnups for the Arrival Scenarios Projected For Years 1999 And 2002

\begin{tabular}{|c|c|c|}
\hline Case for 63,000 MTHM & $\begin{array}{c}\text { 1999 Projected } \\
\text { Average Burnup } \\
\text { (GWd/MTU) }\end{array}$ & $\begin{array}{c}\text { Ratios To } \\
\text { 1999 Case A }\end{array}$ \\
\hline $\mathrm{A}$ & 38 & 1.00 \\
\hline $\mathrm{B}$ & 39 & 1.03 \\
\hline $\mathrm{C}$ & 37 & 0.97 \\
\hline & $\begin{array}{c}\text { 2002 Projected } \\
\text { Average Burnup } \\
\text { GWd/MTU }\end{array}$ & \\
\hline $\mathrm{A}^{\prime}$ & 36 & 0.95 \\
\hline $\mathrm{B}^{\prime}$ & 44 & 1.16 \\
\hline $\mathrm{C}^{\prime}$ & 47 & 1.24 \\
\hline $\mathrm{D}^{\prime}$ & 49 & 1.29 \\
\hline & & \\
\hline & min & 0.95 \\
\hline & max & 1.29 \\
\hline & &
\end{tabular}

NOTES: The three 1999 arrival forecasts A to C (CRWMS M\&O 2000 [DIRS 138239], Tables 10, 12, and 14) and four 2002 arrival forecasts, A' to D' (BSC 2003 [DIRS 165990] 3.2.1 and Tables 2 and 4).

\subsubsection{DSNF Waste}

The inventory estimates given provide a nominal and a bounding radionuclide inventory for the many heterogeneous types of DOE-owned spent nuclear fuels (DSNFs) (DOE 2003 [DIRS 163377]). Although the bounding radionuclide inventory estimates were provided to assess the preclosure risk associated with handling a worst-case canister, the values have also been used to represent a bounding inventory for assessing postclosure risk. In Appendix III, Microsoft Excel workbook: inv_rev1.xls, worksheet DSNF uncert, the nominal and bounding grams per package (gpp) for the weighted average of DSNF waste were analyzed, excluding the bare commercial PWR and BWR assemblies in DOE's possession (DOE 2003 [DIRS 163377]). The source of inventory data for DSNF (DOE 2003 [DIRS 163377]) and the canister count (DOE 2004 [DIRS 169354] are qualified for intended use in Appendix IV.

Source Term Estimates for DOE Spent Nuclear Fuels (DOE 2004 [DIRS 169354], p. 38) determined that bounding burnup information was not available to support inventory calculations. Therefore, the nominal burnup was estimated and the bounding burnup was conservatively assumed to be two times $(2 \times)$ the nominal burnup (DOE 2004 [DIRS 169354], p. 38). Thus, the ratio of the bounding to nominal grams per package for each isotope ranges from approximately one to two. Source Term Estimates for DOE Spent Nuclear Fuels (DOE 2003 [DIRS 163377], p. 39) reports that 38 percent of the DSNF inventory comes from 0.31 percent of the total DSNF. This 0.31 percent of the mass relied on conservative assumptions to compensate for missing information. If we can assume that 0.31 percent of the fuel can be represented by the 99.69 percent of the DSNF with sufficient information, we can conclude that the expected inventory is more reasonably represented as 62 percent of the nominal. See assumption in Section 5.2. 
In addition to the uncertainty of the DSNF inventory, there is the uncertainty associated with the loading of the DSNF waste into DSNF canisters. The 2004 DOE report states that the "Spent Fuel Database" provides point estimates of the number of U.S. DSNF canisters required for all DSNF (DOE 2004 [DIRS 169354] Appendix F, p. F-3). In 2003, Source Term Estimates for DOE Spent Nuclear Fuels REV 0 (DOE 2003 [DIRS 163377]) used a canister count of 3,607. Revision 1 of that report (DOE 2004 [DIRS 169354] p. 41) provides a DSNF canister count range of 2,500 to 5,000 to include uncertainty. Using the canister counts to examine the uncertainty used here, applying a factor based on the ratio of 3,607/2,500 to the maximum of 1.99 (DSNF_uncert worksheet) and 3607/5000 to the "reasonable" inventories (i.e., 0.62 of the nominal (DSNF_uncert worksheet), yields a maximum and minimum of 2.90 and 0.45 , respectively). As noted in Source Term Estimates for DOE Spent Nuclear Fuels (DOE 2003 [DIRS 163377]), the best estimate of the inventory is the inventory that is represented by 0.62 of the nominal inventory. The minimum, reasonable, and maximum DSNF radionuclide inventories associated with the 2003 data are shown in Figure 6-7.

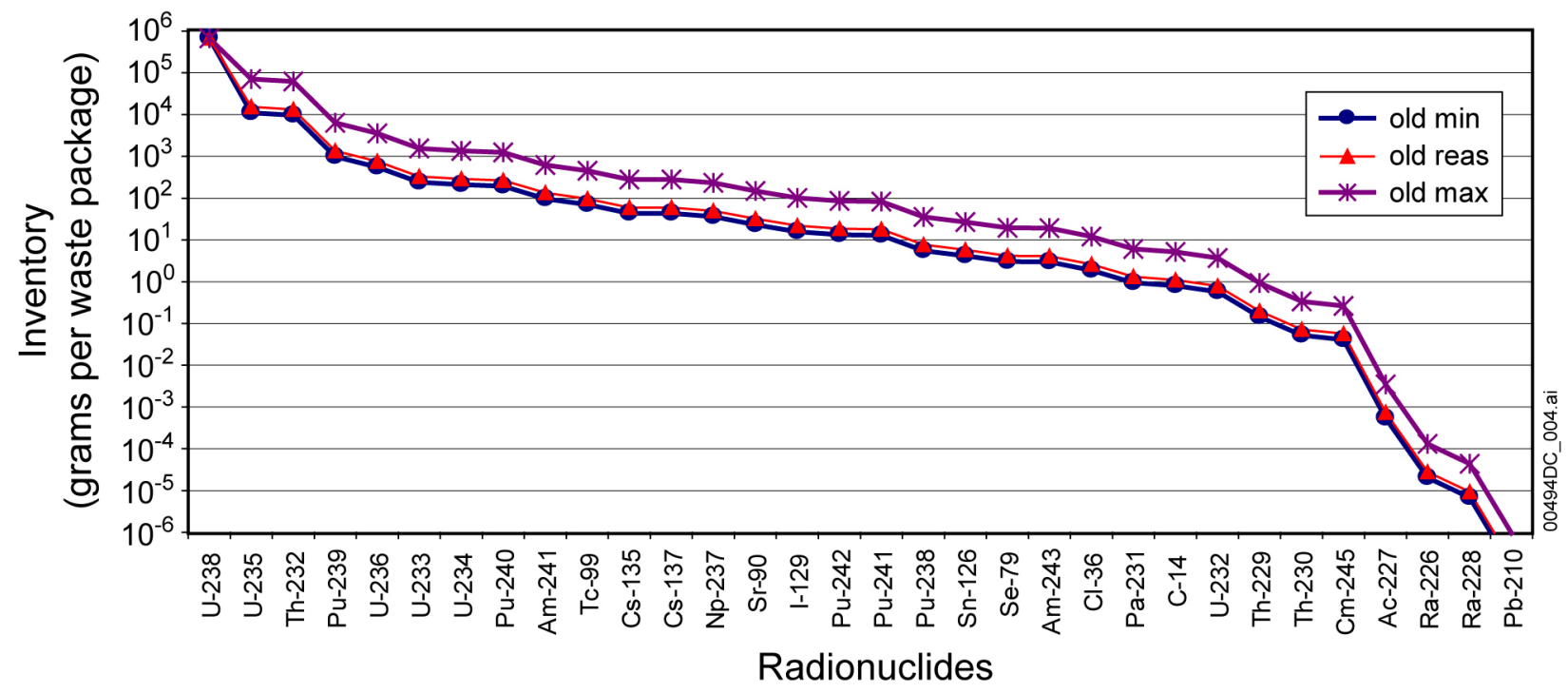

Source: DOE 2003 [DIRS 163377]; Appendix III Microsoft Excel workbook: inv_rev1.xls, worksheet chart DSNF uncert.

Figure 6-7. Uncertainty in 2003 DSNF Radionuclide Inventory Estimates

Since this analysis uses inventory data from Source Term Estimates for DOE Spent Nuclear Fuels (DOE 2003 [DIRS 163377]), a comparison has been made of the two inventories (i.e., against DOE 2004 [DIRS 169354]). The results are plotted on a log scale in Figure 6-8 and Figure 6-9. These data are provided in worksheets described in Appendix II and provided on the Appendix III CD. As can be seen in Figure 6-8, the 2003 data used in this analysis tracks closely with 2004 data. Both "old max" and "old min" inventory projections are bounded by the uncertainty calculated for the 2003 data (Figure 6-9). In fact, the 2004 report states that the "net impact of the changes on the total estimated radionuclide inventory" based on updates to the DOE spent nuclear fuel database "was an 2\% decrease for the bounding case and an $\sim 14 \%$ decrease for the nominal case. An assessment of the impacts concluded that these changes are not expected to impact the repository licensing basis" (DOE 2004 [DIRS 169354], p. 7). Therefore, the analysis performed using the 2003 DSNF inventory is valid for TSPA-LA. 


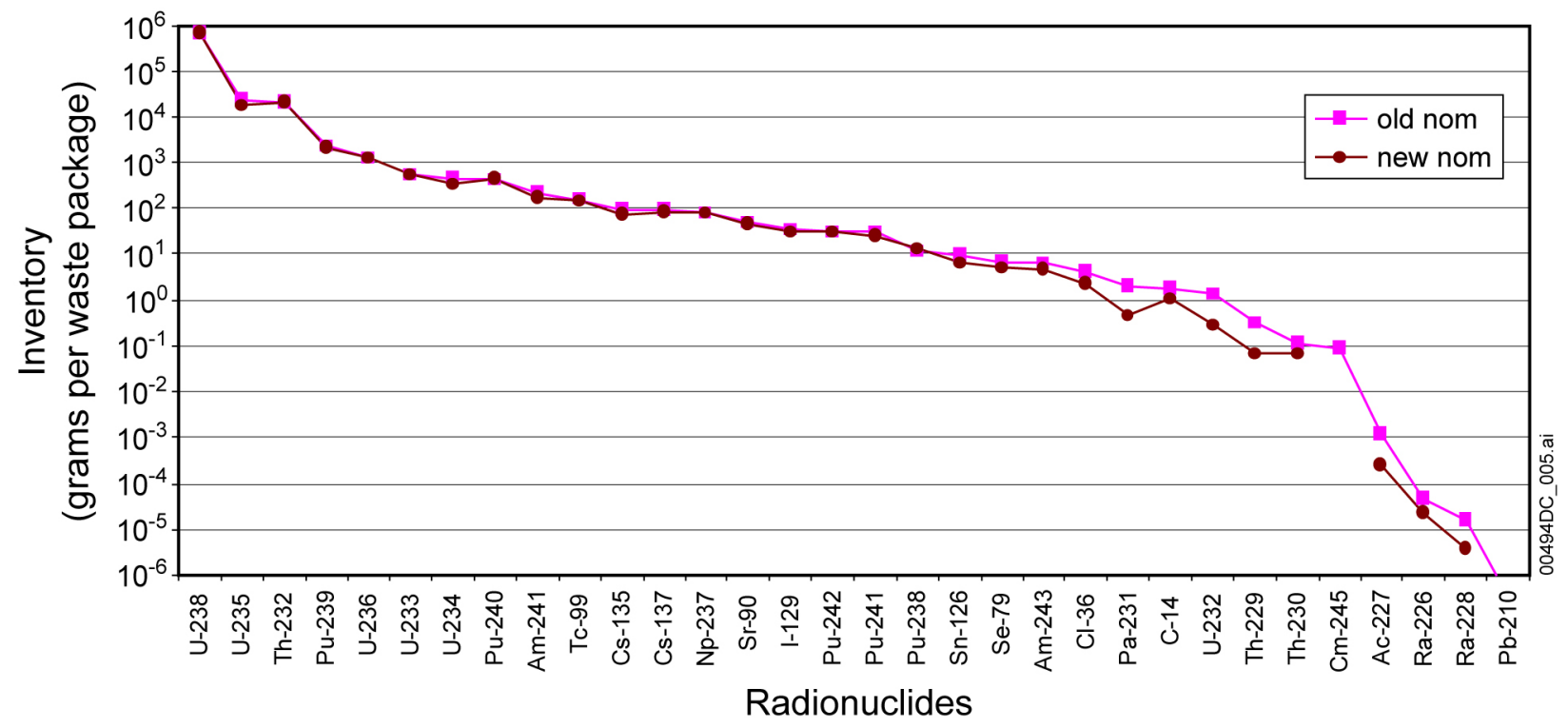

Source: DOE 2003 [DIRS 163377] and DOE 2004 [DIRS 169354]; Appendix III Microsoft Excel workbook: inv_rev1.xls, worksheet, DSNF compare plots.

Figure 6-8. Comparison of the Nominal Radionuclide Inventory for 2003 (old nom) and 2004 (new nom)

Like CSNF, the uncertainties of the DSNF radionuclide inventories are correlated and an uncertainty multiplier is defined to capture the uncertainty for all radionuclides except ${ }^{238} \mathrm{U}$. The inventory of ${ }^{238} \mathrm{U}$ is well known for DSNF and has much less relative uncertainty than the other radionuclides because it is present in the initial fuel and generally changes little during reactor operation. This is seen in Figures 6-7, 6-8, and 6-9. Defining a probability distribution for the DSNF multiplier, three points are provided: a minimum value, expected or "most likely" value and a bounding value. In this situation, using a triangular distribution is reasonable to best estimate the range of the data. Thus, the DSNF multiplier is defined as a triangular distribution, with a minimum of 0.45 , a "most likely" value of 0.62 , and a maximum value of 2.90 . These factors have been applied to the nominal values for DSNF grams per package in Table 7-1 for all isotopes except ${ }^{238} \mathrm{U}$. Figures 6-8 and 6-9 plot the data applying these factors to the radionuclide inventory identified in the DOE 2003 and the DOE 2004 reports (old nom overlaid on new nom in Figure 6-8; old nom, old reas, old bound, old max overlaid on new nom, new reas, new bound, new max in Figure 6-9).

For the "new" data plotted in Figures 6-8 and 6-9, it is noted in the 2004 report (DOE 2004 [DIRS 169354]) that 17.4 percent of the 2004 radionuclide inventory comes from the results of 0.2 percent of the total DSNF. This 0.2 percent of the mass relied heavily on conservative assumptions to compensate for missing information. Consequently, by assuming 0.2 percent of the DSNF with insufficient information can be reasonably represented by the 99.8 percent of DSNF inventory with sufficient information, one may conclude that the total radionuclide inventory associated with DSNF is more reasonably about 83 percent of the nominal inventory estimated. This is compared to the DOE 2003 report estimates that 38 percent of the DSNF radionuclide inventory comes from 0.31 percent of the DSNF inventory. The 0.31 percent with insufficient information is represented by the 99.69 percent of the DSNF inventory with sufficient information such that the "expected value" for the radionuclide inventory is "reasonably about 62\% of the nominal inventory estimated" (DOE 2003 [DIRS 163377]). 


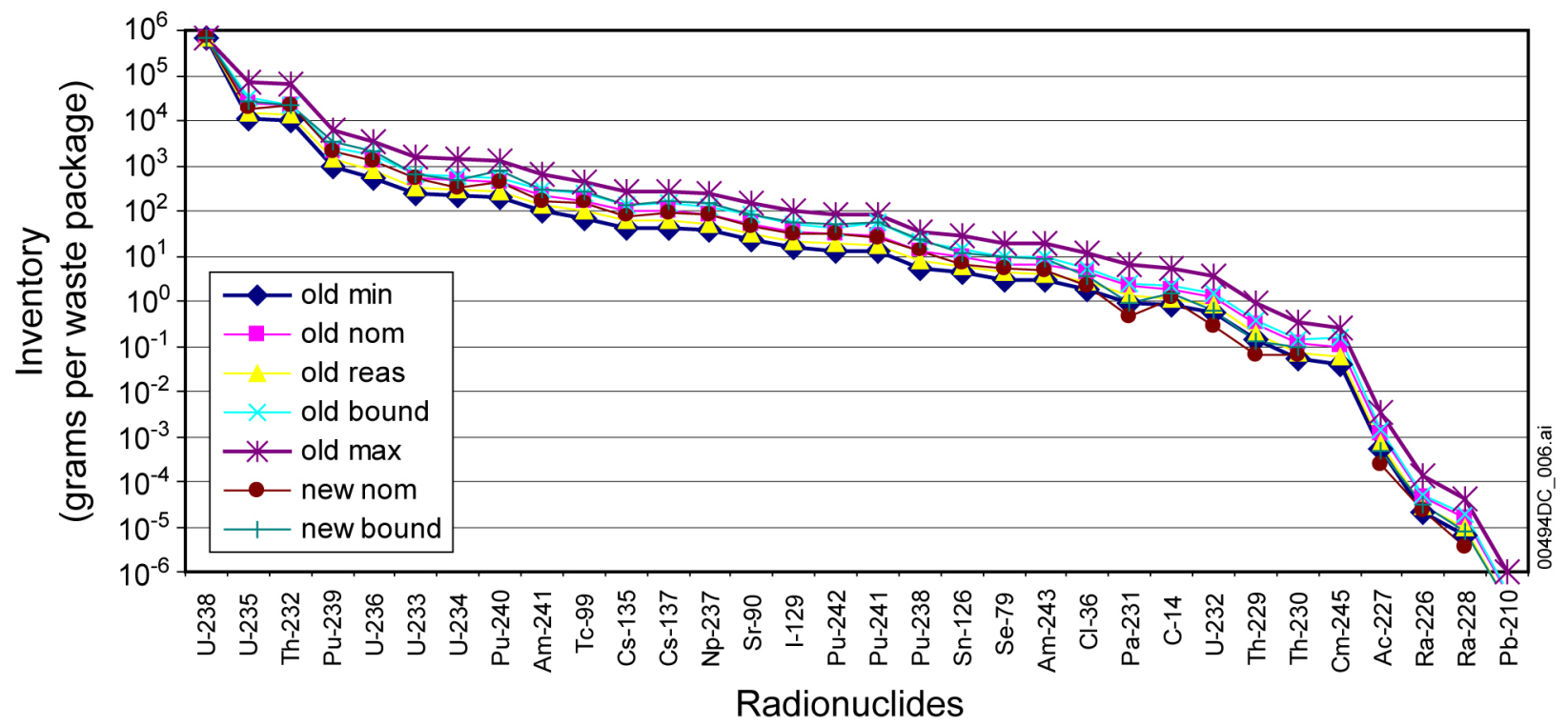

Source: DOE 2003 [DIRS 163377] and DOE 2004 [DIRS 169354]; Appendix III Microsoft Excel workbook: inv_rev1.xls, worksheet, DSNF compare plots.

Figure 6-9. Comparison of the 2003 and 2004 DSNF Radionuclide Inventories

\subsubsection{HLW Glass Waste}

Earlier determinations of HLW inventories such as Inventory Abstraction (BSC 2001 [DIRS 157575]) used information for glass from four sites: 1) Hanford, (2) INEEL, (3) Savannah River Site (SRS), and (4) the West Valley Demonstration Project. The estimated inventories per package from the four sites were heterogeneous. In that analysis, the SRS and Hanford glass packages dominated the radionuclide content of the glass inventory. Since that analysis, new information has been reported from SRS (Allison 2004 [DIRS 168734], Appendix 1) and Hanford (Hamel 2003 [DIRS 164947]). These sources are used in this analysis as the basis for the radionuclide content HLW and are expected to bound the HLW inventory for TSPA-LA. Qualification of data from Allison 2004 is provided in Appendix IV.1; data from Hamel (2003 [DIRS 164947]) is qualified in Appendix IV.2)

The new HLW calculations use the data for the Savannah River HLW glass inventory (Allison 2004 [DIRS 168734], Appendix 1) and are shown in Table 4-9. The Hanford canister production and waste loading estimates are shown in Tables 4-10 and 4-11 (Hamel 2003 [DIRS 164947]). These data were used to compare the difference between the old (CRWMS M\&O 2000 [DIRS 151947]) and new estimates for average short and long canister radionuclide inventories as shown in Figure 6-10. This comparison does not imply that the two inventories are intended to match each other. Source Terms of HLW Glass (CRWMS M\&O 2000 [DIRS 151947]) is used by TSPA-LA for heat calculations, whereas this document is used by TSPA-LA for the radionuclide inventory.

Data for curies per SRS batch and curies for all of Hanford HLW for the year 2030 were collected and converted to curies per canister based on the inventory for 32 radionuclides from Table 6-2 and a weighted average is calculated based on the new number of canisters in new configurations. The average ratio of new/old inventories for isotopes reported with greater than 
$1 \times 10^{-6}$ grams was 3.4 for short canisters and 1.8 for long canisters. The new information for short canisters (Allison 2004 [DIRS 168734], Appendix 1, Tables 5 to 8) provide the curies per canister decayed to the year 2030 for batches of SRS glass already poured (batch 1A, year 1994; batch 1B, year 2000; and batch 2 and 3, year 2002) and for those in the future (batches 4 through 10). Figure 6-11 shows the estimated radionuclide inventories for those batches, which show significant heterogeneity. It can also be seen that the future batches dominate the average.

New long canister information for Hanford shown in Table 4-11 (Hamel 2003 [DIRS 164947], p. 1-9, Tables 1-3) shows the expected production of canisters for the program, planning, and technology cases based on three canister-fill scenarios: maximum fill (100 percent), WTP contract fill (95 percent), and minimum fill ( 87 percent). The data in Table 4-11 are used to develop the uncertainty distribution as discussed in Section 6.6.3.

Canister production estimates take into account three assumed levels of waste loadings in weight-percent (wt \%). The Program case assumes an effective waste loading of $27.7 \mathrm{wt} \%$; the planning case assumes an effective waste loading of $36.3 \mathrm{wt} \%$; and the technology case assumes an effective waste loading of $45 \mathrm{wt} \%$. Therefore, for radionuclide loading, the program case with the lowest waste loading (27.7) results in the maximum number of HLW canisters for the three canister-fill scenarios. The planning case, with 36.3 percent waste loading yields the nominal, expected number of HLW canisters for the three canister-fill scenarios. The technology case, which requires new technology to increase the radionuclide waste-loading capability to $45.0 \mathrm{wt} \%$, yields the minimum the number of canisters needed to store the waste inventory for the three canister-fill scenarios (Hamel 2003 [DIRS 164947], p.1-9 and Tables 1 to 3). For canister-fill scenarios, the LA case is the contract case of 95 percent full.

Like that of CSNF and DSNF, the uncertainties in HLW radionuclide inventories are not independent. In this case, the inventories are dependent on radionuclide loading (wt \%) per canister; therefore, an uncertainty multiplier is used. With the current information, the nominal values reported in Table 7-1 are the "most likely" values and, thus, the "most likely" value for the uncertainty multiplier is one. The "most likely" value corresponds to the expected/nominal number of Hanford HLW canisters shown at center of the matrix listed in Table 4-11 (i.e., the planning case and contract fill scenario of 95 percent yielding 9,202 canisters per waste packages). The minimum uncertainty multiplier of 0.70 is obtained from the ratio of the nominal number of canisters per waste packages $(9,202)$ to the maximum number of canisters per waste packages $(13,205)$. An uncertainty ratio of 1.3 is derived from the nominal number of canisters/waste packages $(9,202)$ to the minimum number of canisters per waste packages $(7,071)$. However, because of the uncertainty in possible new vitrified waste forms at SRS with loading up to 50 percent and higher, it is prudent to be conservative in the estimate of the upper limit. Therefore, conservatively estimating increase in waste loading of $7 \mathrm{wt} \%$ above that specified for the technology case and applying it to the 100-percent fill scenario, this new maximum loading of 52 percent provides a margin, which corresponds to a ratio of 1.5 . With the "most likely," the maximum, and the minimum values defined, a triangular distribution is chosen for the HLW uncertainty multiplier used by TSPA. This multiplier is to be applied to the nominal HLW inventories shown in Table 7-1 for all isotopes (including ${ }^{238} \mathrm{U}$ ). The uncertainty multiplier using a triangular distribution has a minimum of 0.7 , a "most likely" value of 1.0, and a maximum value of 1.5 . 


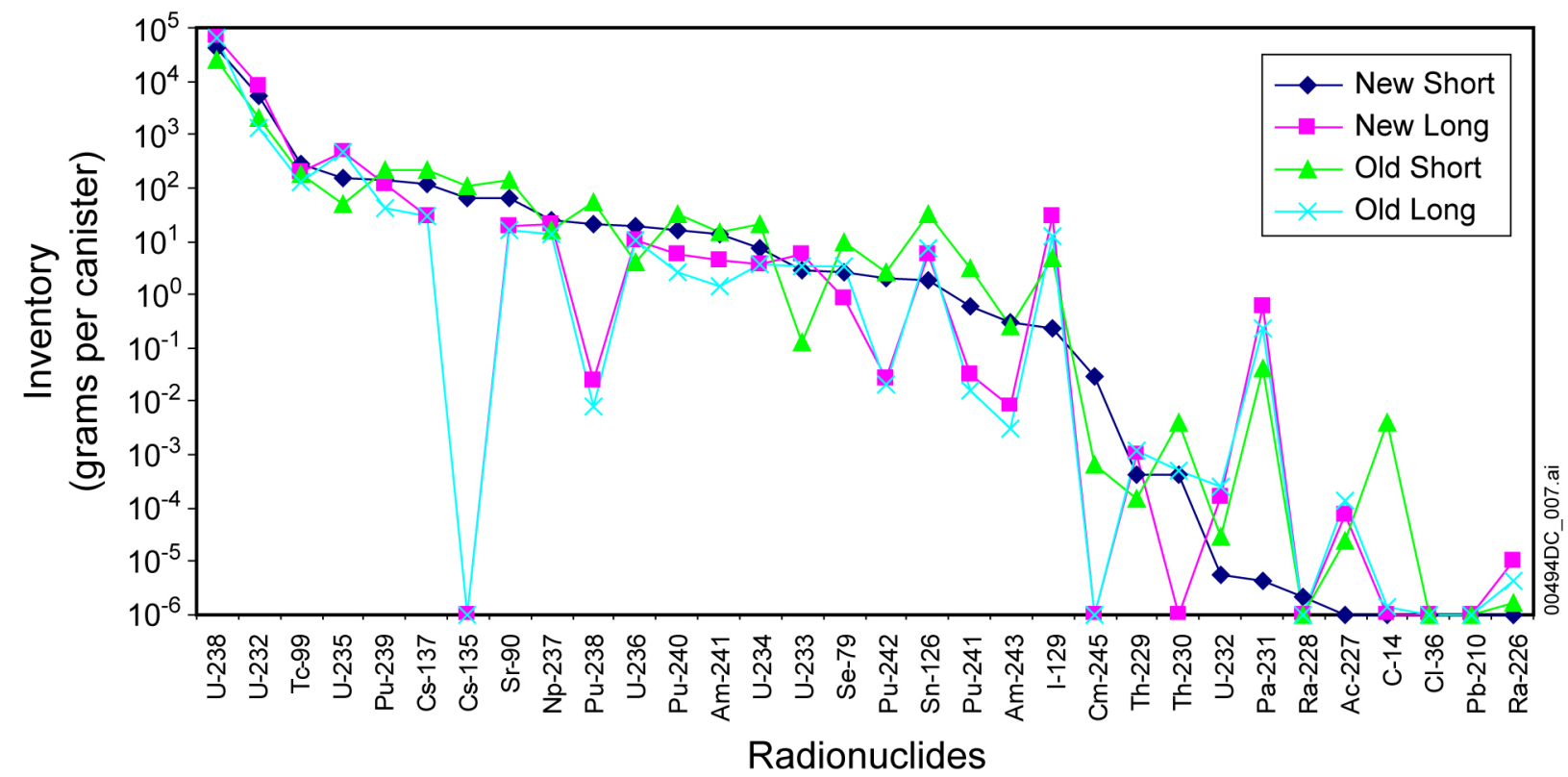

Source: CRWMS M\&O 2000 [DIRS 151947]; Hamel 2003 [DIRS 164947]; Allison 2004 [DIRS 168734], Appendix I; Appendix III Microsoft Excel workbook: inv_rev1.x1s, worksheet - newHLW32 .

NOTE: Values less than $10^{-6}$ have been truncated to $10^{-6}$ for plotting purposes.

Figure 6-10. Radionuclide Inventories of the Older and Newer Estimates for Average Short and Long HLW Glass Canisters

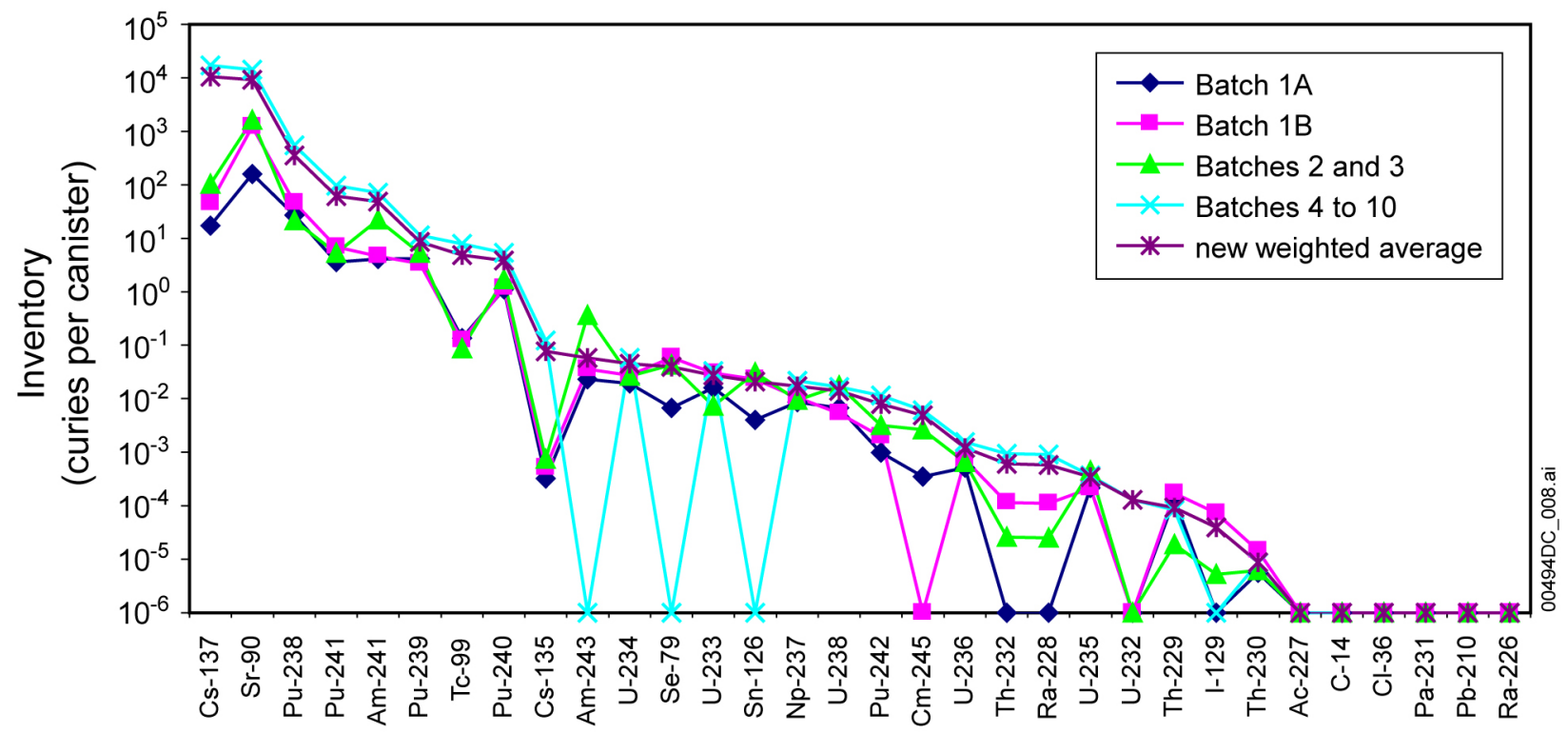

Radionuclides

Source: Allison 2004 [DIRS 168734], Appendix 1; Appendix III Microsoft Excel workbook: inv_rev1.xls, worksheet newSRSbatches.

NOTE: Values less than $10^{-6}$ have been truncated to $10^{-6}$ for plotting purposes.

Figure 6-11. SRS Glass Batch Inventories 


\subsection{INTENDED USE OF OUTPUT DATA}

The output from this inventory analysis will be used as a direct input to the TSPA-LA and is limited to postclosure analysis. The calculations were performed in this report uses year-specific inventories from direct inputs described in Section 4 and identified in Table 4.1: 2033 for CSNF, and 2030 for HLW and DSNF. This report provides the inventories at years 2033 and 2030 that TSPA-LA will use to model that inventory at 2060. The data are reported with uncertainties due to many assumptions used to derive waste inventories. Several of these uncertainties have been discussed and applied both in the derivation of the source data used in this analysis and application of these data in this analysis. The effects of conservative assumptions used to compensate for missing information clearly show an inverse correlation between the available information used in the methodology and the resulting radionuclide concentrations estimated.

In the selection of radionuclides for initial inventory analysis, radioactive decay, and in-growth were considered. The daughter radionuclides of these processes, along with parent radionuclides are included in the list of screened radionuclides for the TSPA-LA (BSC 2002 [DIRS 160059]). Radioactive decay and in-growth can be used to reduce the number of isotopes carried by the TSPA-LA calculations. For example, in the chain ${ }^{245} \mathrm{Cm} \rightarrow{ }^{241} \mathrm{Pu} \rightarrow{ }^{241} \mathrm{Am},{ }^{241} \mathrm{Am}$ is screened in as an important isotope, but ${ }^{245} \mathrm{Cm}$ and ${ }^{241} \mathrm{Pu}$ are not. To account for the in-growth of ${ }^{241} \mathrm{Am}$ from these isotopes, they can be included in the TSPA-LA calculation, or they can be artificially decayed to ${ }^{241} \mathrm{Am}$ to augment the ${ }^{241} \mathrm{Am}$ at the start of the calculation.

The output of this analysis is shown in Tables 7-1 and 7-2. The values from Table 7-1 are to be used as the nominal values. For scenarios where many packages breach, the uncertainties for most radionuclide inventories are modeled with the uncertainty multipliers shown in Table 7-2. Because the uncertainty multipliers specifically address the heterogeneity of the waste form inventory per package, the inclusion of these uncertainty multipliers in the TSPA-LA disposition provides for a direct implementation of FEP 2.1.01.03.0A regarding heterogeneity of the waste package in the TSPA-LA model. The isotopes ${ }^{36} \mathrm{Cl},{ }^{79} \mathrm{Se},{ }^{126} \mathrm{Sn}$, and ${ }^{210} \mathrm{~Pb}$ have been included in Table 7-1 to retain a capability to meet the needs of the million-year calculations, but are not required for the 10,000-year calculations. The list of radionuclides identified for the regulatory period (i.e., 10,000 years did not change when the screening analysis was extended to 20,000 years).

In Appendix I, the analysis of activation products show that 18 percent of the ${ }^{14} \mathrm{C}$ inventory in CSNF is calculated to originate from neutron activation of stainless steel hardware outside the fuel rods. For the TSPA-LA model this inventory was considered to be an unbound inventory, available for immediate release after potential breach of the waste package. 
INTENTIONALLY LEFT BLANK 


\section{CONCLUSIONS}

This analysis uses the most recent radionuclide information for CSNF, DSNF, and HLW to provide nominal radionuclide inventory in grams per package and uncertainty distributions for radionuclides important to dose calculations for TSPA-LA. A revision of a report providing source term estimates for DOE spent nuclear fuels (DSNF) was released by the U.S. DOE National Spent Nuclear Fuel Program in January 2004 (DOE 2004 [DIRS 169354]). The data in that revision (DOE 2004 [DIRS 169354]) was compared to the previous revision of the same report released in March 2003 (DOE 2003 [DIRS 163377]) that was the source of radionuclide inventory data used in this analysis. These comparisons are presented in Section 6.6.2, Figures 6-8 and 6-9. As noted in the revised report (DOE 2004 [DIRS 169354]):

Subsequent to the original March 2003 issue of this report, the National Spent Nuclear Fuel Program Spent Fuel Database has been updated to Version 5.0.1. This revision incorporates information from Version 5.0.1 of the Spent Fuel Database. The net impact of the changes on the total estimated radionuclide inventory was an $\sim 2 \%$ decrease for the bounding case and an $\sim 14 \%$ decrease for the nominal case. An assessment of the impacts concluded that these changes are not expected to impact the repository licensing basis.

Therefore, the DSNF radionuclide inventory analyzed and reported in Table 7-1 is valid and bounding. The sources of data for CSNF (CRWMS M\&O 2000 [DIRS 138239]) and Waste Stream Projections Report (BSC 2003 [DIRS 165990])) and DHLW glass (memorandums by Hamel (2003 [DIRS 164947]) and Allison (2004 [DIRS 168734], Appendix 1)) are the most recent available.

Data used as direct input to analyses must meet the definition of "qualified data" in accordance with AP-3.15Q, Managing Technical Product Inputs. Data (BSC 2003 [DIRS 165990]; Hamel 2003 [DIRS 164947]; and Allison 2004 [DIRS 168734]) have been qualified in Appendix IV in accordance with procedural requirements (AP-SIII.9Q and AP-SIII.2Q) that are part of Quality Assurance Requirements and Description (DOE 2004 [DIRS 171539]) definitions for "Qualification of Data."

The initial radionuclide inventory represents that inventory of radionuclides that has been identified as being important to dose. The quantity and activity of these radionuclides have been modeled and these data reported in referenced documents to the year of projected emplacement; 2033 for CSNF, 2030 for DSNF and HLW. This analysis used the modeled inventory data provided by the referenced sources and calculated the total grams for each of the 28 radionuclides identified for the 10,000-year regulatory period required for the TSPA-LA and four additional radionuclides for the FEIS million-year calculations. Based on the configuration, quantity, and capacity of waste package types, this analysis provides TSPA-LA with the nominal grams per waste package of these radionuclides for each type of waste. The total number of waste packages for each waste type (i.e., CSNF, DSNF, and HLW) is also provided. In addition, this analysis provides uncertainty multipliers for inventory of radionuclides for each waste type (CSNF, DSNF, and HLW). These data will be used by the TSPA-LA to model the inventory to the year 2060, the projected repository closure. 


\subsection{INITIAL RADIONUCLIDE INVENTORIES}

The output of this analysis is provided in Tables 7-1 and 7-2 and reported in DTN: SN0310T0505503.004; only the three significant figures shown are to be used. The DTN numbers should not be reformatted to show more significant numbers, because these additional significant numbers are meaningless and have changed slightly. The numbers reported here were formatted by Microsoft Excel to three significant figures and were not rounded. See Table 6-2 for the list of radioisotopes directly screened in, and for the list of radionuclides that were not directly screened in by the analysis, but should be accounted for in the inventory, either by direct inclusion, or by appropriate augmentation of the daughter product. These results are provided for repositoryscale postclosure calculations and are restricted to that use.

Table 7-1. Nominal Grams per Waste Package of Radionuclides for Each Type of Waste

\begin{tabular}{|c|c|c|c|}
\hline \multirow[b]{2}{*}{ Radionuclide } & \multicolumn{3}{|c|}{ Grams per Waste Package } \\
\hline & CSNF & DSNF & HLW \\
\hline${ }^{227} \mathrm{Ac}$ & $2.50 \mathrm{E}-06$ & $1.20 \mathrm{E}-03$ & $2.07 \mathrm{E}-04$ \\
\hline${ }^{241} \mathrm{Am}$ & $8.28 \mathrm{E}+03$ & $2.15 \mathrm{E}+02$ & $4.07 \mathrm{E}+01$ \\
\hline${ }^{243} \mathrm{Am}$ & $1.26 \mathrm{E}+03$ & $6.63 \mathrm{E}+00$ & $6.24 \mathrm{E}-01$ \\
\hline${ }^{14} \mathrm{C}^{\mathrm{a}}$ & $1.37 E+00$ & $1.78 \mathrm{E}+00$ & $0.00 \mathrm{E}+00^{\mathrm{c}}$ \\
\hline${ }^{36} \mathrm{Cl}^{\mathrm{b}}$ & $3.27 E+00$ & $4.17 \mathrm{E}+00$ & $0.00 \mathrm{E}+00^{\mathrm{c}}$ \\
\hline${ }^{245} \mathrm{Cm}$ & $1.77 \mathrm{E}+01$ & $9.11 \mathrm{E}-02$ & 5.89E-02 \\
\hline${ }^{135} \mathrm{Cs}$ & $4.41 \mathrm{E}+03$ & $9.59 \mathrm{E}+01$ & $1.38 \mathrm{E}+02$ \\
\hline${ }^{137} \mathrm{Cs}$ & $5.97 \mathrm{E}+03$ & $9.57 \mathrm{E}+01$ & $3.28 \mathrm{E}+02$ \\
\hline${ }^{129} I$ & $1.75 \mathrm{E}+03$ & $3.51 \mathrm{E}+01$ & $7.89 \mathrm{E}+01$ \\
\hline${ }^{237} \mathrm{~Np}$ & $4.63 \mathrm{E}+03$ & $8.02 \mathrm{E}+01$ & $1.08 \mathrm{E}+02$ \\
\hline${ }^{231} \mathrm{~Pa}$ & $9.28 \mathrm{E}-03$ & $2.11 \mathrm{E}+00$ & $1.66 \mathrm{E}+00$ \\
\hline${ }^{210} \mathrm{~Pb}^{\mathrm{b}}$ & $0.00 \mathrm{E}+00^{c}$ & 3.30E-07 & $3.69 \mathrm{E}-10$ \\
\hline${ }^{238} \mathrm{Pu}$ & $1.54 \mathrm{E}+03$ & $1.23 \mathrm{E}+01$ & $4.24 \mathrm{E}+01$ \\
\hline${ }^{239} \mathrm{Pu}$ & $4.37 E+04$ & $2.18 \mathrm{E}+03$ & $6.06 \mathrm{E}+02$ \\
\hline${ }^{240} \mathrm{Pu}$ & $2.08 E+04$ & $4.28 \mathrm{E}+02$ & $5.01 \mathrm{E}+01$ \\
\hline${ }^{241} \mathrm{Pu}$ & $2.69 \mathrm{E}+03$ & $2.88 \mathrm{E}+01$ & $1.32 \mathrm{E}+00$ \\
\hline${ }^{242} \mathrm{Pu}$ & $5.34 \mathrm{E}+03$ & $2.97 \mathrm{E}+01$ & $4.22 \mathrm{E}+00$ \\
\hline${ }^{226} \mathrm{Ra}$ & $0.00 \mathrm{E}+00^{c}$ & $4.50 \mathrm{E}-05$ & 2.63E-05 \\
\hline${ }^{228} \mathrm{Ra}$ & $0.00 \mathrm{E}+00^{\mathrm{c}}$ & 1.49E-05 & 6.51E-06 \\
\hline${ }^{79} \mathrm{Se}^{\mathrm{b}}$ & $4.24 \mathrm{E}+01$ & $6.72 \mathrm{E}+00$ & $7.61 \mathrm{E}+00$ \\
\hline${ }^{126} \mathrm{Sn}^{\mathrm{b}}$ & $4.69 \mathrm{E}+02$ & $9.26 \mathrm{E}+00$ & $1.85 \mathrm{E}+01$ \\
\hline${ }^{90} \mathrm{Sr}$ & $2.52 \mathrm{E}+03$ & $5.14 \mathrm{E}+01$ & $1.89 \mathrm{E}+02$ \\
\hline${ }^{99} \mathrm{Tc}$ & $7.64 \mathrm{E}+03$ & $1.56 \mathrm{E}+02$ & $1.10 \mathrm{E}+03$ \\
\hline${ }^{229} \mathrm{Th}$ & $0.00 \mathrm{E}+00^{c}$ & 3.19E-01 & 3.58E-03 \\
\hline${ }^{230} \mathrm{Th}$ & $1.54 \mathrm{E}-01$ & 1.16E-01 & 8.81E-04 \\
\hline${ }^{232} \mathrm{Th}$ & $0.00 \mathrm{E}+00^{\mathrm{c}}$ & $2.14 \mathrm{E}+04$ & $3.23 E+04$ \\
\hline${ }^{232} \mathrm{U}$ & 1.03E-02 & $1.26 \mathrm{E}+00$ & 4.43E-04 \\
\hline${ }^{233} \mathrm{U}$ & 5.83E-02 & $5.30 \mathrm{E}+02$ & $2.11 \mathrm{E}+01$ \\
\hline${ }^{234} \mathrm{U}$ & $1.77 \mathrm{E}+03$ & $4.66 \mathrm{E}+02$ & $2.53 \mathrm{E}+01$ \\
\hline${ }^{235} \mathrm{U}$ & $6.34 \mathrm{E}+04$ & $2.47 \mathrm{E}+04$ & $1.53 \mathrm{E}+03$ \\
\hline${ }^{236} \mathrm{U}$ & $3.89 E+04$ & $1.23 E+03$ & $6.50 \mathrm{E}+01$ \\
\hline${ }^{238} \mathrm{U}$ & $7.92 E+06$ & $6.74 \mathrm{E}+05$ & $2.57 \mathrm{E}+05$ \\
\hline
\end{tabular}

Output DTN: SN0310T0505503.004.

Source: Appendix III Microsoft Excel workbook: inv_rev1.xls, worksheet inv32.

NOTES: Year of projection: CSNF, 2033; DSNF, 2030; and HLW, 2030

Total number of waste packages is 11,184 (7,772 CSNF and 3,412 Codisposal)

a 18 percent of ${ }^{14} \mathrm{C}$ for CSNF originates from activation of the hardware outside of the cladding.

b Isotopes not needed for 10,000-year regulatory period, but included to retain ability to perform millionyear calculations.

Grams listed as $0.00 \mathrm{E}+00$ is the value presented in the data input source. 
Table 7-2. Uncertainty Multipliers for Grams per Package of Radionuclides for Each Waste Type

\begin{tabular}{|l|l|l|l|}
\hline & \multicolumn{1}{|c|}{ CSNF } & \multicolumn{1}{|c|}{ DSNF } & \multicolumn{1}{c|}{ HLW } \\
\hline Isotopes & All except ${ }^{238} \mathrm{U}$ & All except ${ }^{238} \mathrm{U}$ & All \\
\hline Distribution & Uniform & Triangular & Triangular \\
\hline Minimum & 0.85 & 0.45 & 0.70 \\
\hline "Most Likely" & $\mathrm{N} / \mathrm{A}$ & 0.62 & 1 \\
\hline Maximum & 1.40 & 2.90 & 1.5 \\
\hline
\end{tabular}

Output DTN: SN0310T0505503.004.

Source: Appendix III Microsoft Excel workbook: inv_rev1.xls, worksheet inv32.

\subsection{YUCCA MOUNTAIN REVIEW PLAN ACCEPTANCE CRITERIA}

The following acceptance criteria from Section 2.2.1.3.4.3 of Yucca Mountain Review Plan, Final Report (NRC 2003 [DIRS 163274]) are based on meeting the relevant requirements of 10 CFR 63.114(a) to (c) and (e) to (g) [DIRS 156605], as they relate to the radionuclide release rates and solubility limits model abstraction. For each applicable criterion, the criterion is quoted, followed by pointers to the information addressing the criterion. In some cases, the criterion is shared by more that one analysis/model report. These criteria will be fully addressed when related reports are complete.

\section{Acceptance Criterion 1-System Description and Model Integration Are Adequate}

(1) TSPA adequately incorporates important design features, physical phenomena, and couplings, and uses consistent and appropriate assumptions throughout the radionuclide release rates and solubility limits abstraction process;

The input to this analysis in Section 4.1 came from the cited documents. The physical process of decay and in-growth is accounted for. The discretization of the inventory and the form of the uncertainty were consistent with TSPA analysis.

(2) The abstraction of radionuclide release rates and solubility limits uses assumptions, technical bases, data, and models that are appropriate and consistent with other related U.S. Department of Energy abstractions.

For example, the assumptions used for this analysis are consistent with the abstractions of "Degradation of Engineered Barriers" (Section 2.2.1.3.1); "Mechanical Disruption of Waste Packages" (Section 2.2.1.3.2); "Quantity and Chemistry of Water Contacting Engineered Barriers and Waste Forms" (Section 2.2.1.3.3); "Climate and Infiltration" (Section 2.2.1.3.5); and "Flow Paths in the Unsaturated Zone" (Section 2.2.1.3.6). The descriptions and technical bases provide transparent and traceable support for the abstraction of radionuclide release rates and solubility limits;

The technical bases and data are appropriate but not always consistent. Differences between Tables 4-2 and 6-3 are justified in Section 6.2. 
(3) The abstraction of radionuclide release rates and solubility limits provides sufficient, consistent design information on waste packages and engineered barrier systems.

For example, inventory calculations and selected radionuclides are based on the detailed information provided on the distribution (both spatially and by compositional phase) of the radionuclide inventory, within the various types of high-level radioactive waste;

This analysis is based on the detailed information provided on the distribution (both spatially and by compositional phase) of the radionuclide inventory, within the various types of high-level radioactive waste as described in Sections 4 and 6.

(4) to (8)

Not applicable.

\section{Acceptance Criterion 2-Data Are Sufficient for Model Justification}

(1) Not applicable.

(2) Sufficient data have been collected on the characteristics of the natural system and engineered materials to establish initial and boundary conditions for conceptual models and simulations of thermal-hydrologic-chemical coupled processes.

For example, sufficient data should be provided on design features, such as the type, quantity, and reactivity of materials, that may affect radionuclide release for this abstraction;

The data and its uncertainty are discussed in Sections 4.1 and 6.6, respectively.

(3) to (4)

Not applicable.

\section{Acceptance Criterion 3-Data Uncertainty Is Characterized and Propagated Through the} Analysis

(1) Data used for parameter values, assumed ranges, probability distributions, and bounding assumptions that are technically defensible, reasonably account for uncertainties and variabilities, and do not result in an under-representation of the risk estimate;

Data uncertainty is described in Section 6.6.

(2) to (9)

Not applicable. 


\section{INPUTS AND REFERENCES}

\subsection{DOCUMENTS CITED}

168734 Allison, J.M. 2004. "Request for Referenceable Information on High-Level Waste (HLW) Radionuclide Inventories in Support of Preparation of the Yucca Mountain Project License Application (Your Letter, JCP-0445, 1/28/04)." Memorandum from J.M. Allison (DOE/SR) to J. Arthur, III (OCRWM), February 26, 2004, 0303040661, with attachment. ACC: MOL.20040317.0265.

170913 Bowman, S.M. 2002. Configuration Management Plan for the SCALE Code System. SCALE-CMP-001, Rev. 6. Oak Ridge, Tennessee: Oak Ridge National Laboratory. ACC: MOL.20040708.0339.

170910 Broadhead, B.L. 1996. Verification and Validation Plan for the SCALE Code System. SCALE-CCV-001, Rev. 1. Oak Ridge, Tennessee: Oak Ridge National Laboratory. ACC: MOL.20040708.0341.

157575 BSC (Bechtel SAIC Company) 2001. Inventory Abstraction. ANL-WIS-MD-000006 REV 00 ICN 03. Las Vegas, Nevada: Bechtel SAIC Company. ACC: MOL.20020123.0278.

152059 BSC 2001. Performance Assessment of U.S. Department of Energy Spent Fuels in Support of Site Recommendation. CAL-WIS-PA-000002 REV 00. Las Vegas, Nevada: Bechtel SAIC Company. ACC: MOL.20010627.0026.

157450 BSC 2001. Technical Work Plan for: Design Basis Waste Input for License Application. TWP-CRW-SE-000005 REV 00. [Washington, D.C.]: Bechtel SAIC Company. ACC: MOV.20010814.0002.

158966 BSC 2002. The Enhanced Plan for Features, Events, and Processes (FEPs) at Yucca Mountain. TDR-WIS-PA-000005 REV 00. Las Vegas, Nevada: Bechtel SAIC Company. ACC: MOL.20020417.0385.

160059 BSC 2002. Radionuclide Screening. ANL-WIS-MD-000006 REV 01. Las Vegas, Nevada: Bechtel SAIC Company. ACC: MOL.20020923.0177.

165990 BSC 2003. 2002 Waste Stream Projections Report. TDR-CRW-SE-000022 REV 01. Las Vegas, Nevada: Bechtel SAIC Company. ACC: DOC.20031020.0002.

162153 BSC 2003. Clad Degradation - Summary and Abstraction for LA. ANL-WIS-MD000021 REV 00. Las Vegas, Nevada: Bechtel SAIC Company. ACC: DOC.20030626.0002.

163693 BSC 2003. DSNF and Other Waste Form Degradation Abstraction. ANL-WIS-MD000004 REV 02. Las Vegas, Nevada: Bechtel SAIC Company.

ACC: DOC.20030711.0002. 
168795 BSC 2003. In-Package Chemistry for Waste Forms. ANL-EBS-MD-000056 REV 00, with 1 errata. Las Vegas, Nevada: Bechtel SAIC Company.

ACC: MOL.20010322.0490; DOC.20031014.0005.

166296 BSC 2003. Total System Performance Assessment-License Application Methods and Approach. TDR-WIS-PA-000006 REV 00 ICN 01. Las Vegas, Nevada: Bechtel SAIC Company. ACC: DOC.20031215.0001.

169472 BSC 2004. D\&E/PA/C IED Typical Waste Package Components Assembly. 800-IEDWIS0-00202-000-00C. Las Vegas, Nevada: Bechtel SAIC Company. ACC: ENG.20040517.0008.

167321 BSC 2004. CSNF Waste Form Degradation: Summary Abstraction. ANL-EBS-MD000015 REV 01, with 2 errata. Las Vegas, Nevada: Bechtel SAIC Company. ACC: DOC.20030708.0004; DOC.20031224.0001; DOC.20040202.0002.

167058 BSC 2004. PWR and BWR Source Term Sensitivity Study. 000-00C-MGR0-00300000-00A. Las Vegas, Nevada: Bechtel SAIC Company. ACC: ENG.20040114.0003.

171583 BSC 2004. Technical Work Plan For: Regulatory Integration Modeling and Analysis of the Waste Form and Waste Package. TWP-WIS-MD-000009 REV 00 ICN 01. Las Vegas, Nevada: Bechtel SAIC Company. ACC: DOC.20040910.0001.

170020 BSC 2004. Miscellaneous Waste-Form FEPs. ANL-WIS-MD-000009 REV 02. Las Vegas, Nevada: Bechtel SAIC Company.

171407 BSC 2004. D\&E/RIT IED - PWR and BWR Source Term. 000-IED-MGR0-00101000-00A. Las Vegas, Nevada: Bechtel SAIC Company. ACC: ENG.20040812.0032.

171435 BSC 2004. D\&E/RIT IED - PWR and BWR Source Term. 000-IED-MGR0-00104000-00A. Las Vegas, Nevada: Bechtel SAIC Company. ACC: ENG.20040813.0003.

171436 BSC 2004. D\&E/RIT IED - PWR and BWR Source Term. 000-IED-MGR0-00106000-00A. Las Vegas, Nevada: Bechtel SAIC Company. ACC: ENG.20040813.0005.

171502 BSC 2004. D\&E/RIT IED PWR AND BWR SOURCE TERM. 000-IED-MGR000102-000-00A. Las Vegas, Nevada: Bechtel SAIC Company. ACC: ENG.20040813.0001.

171503 BSC 2004. D\&E/RIT IED PWR AND BWR SOURCE TERM. 000-IED-MGR000103-000-00A. Las Vegas, Nevada: Bechtel SAIC Company. ACC: ENG20040813.0002.

166275 Canori, G.F. and Leitner, M.M. 2003. Project Requirements Document. TER-MGRMD-000001 REV 02. Las Vegas, Nevada: Bechtel SAIC Company. ACC: DOC.20031222.0006. 
170914 Carlisle, G. 1999. "SCALE 4.2 Retirement." Memorandum from G. Carlisle to T. Doering, and D. Lancaster, September 3, 1999. ACC: MOL.20020110.0090.

151947 CRWMS M\&O 2000. Source Terms for HLW Glass Canisters. CAL-MGR-NU000002 REV 01. Las Vegas, Nevada: CRWMS M\&O. ACC: MOL.20000823.0004.

153246 CRWMS M\&O 2000. Total System Performance Assessment for the Site Recommendation. TDR-WIS-PA-000001 REV 00 ICN 01. Las Vegas, Nevada: CRWMS M\&O. ACC: MOL.20001220.0045.

150707 CRWMS M\&O 2000. Waste Form Degradation Process Model Report. TDR-WISMD-000001 REV 00 ICN 01. Las Vegas, Nevada: CRWMS M\&O. ACC: MOL.20000713.0362.

138239 CRWMS M\&O 2000. Waste Packages and Source Terms for the Commercial 1999 Design Basis Waste Streams. CAL-MGR-MD-000001 REV 00. Las Vegas, Nevada: CRWMS M\&O. ACC: MOL.20000214.0479.

156084 DeHart, M.D. and Hermann, O.W. 1996. An Extension of the Validation of SCALE (SAS2H) Isotopic Predictions for PWR Spent Fuel. ORNL/TM-13317. Oak Ridge, Tennessee: Oak Ridge National Laboratory. ACC: MOL.19970930.0475.

104384 Dreyfus, D. 1995. "Proposed Mix of DOE-Owned High Level Waste and Spent Nuclear Fuel” Memorandum from D. Dreyfus (DOE/OCRWM) to J.E. Lytle (DOE/OEM), November 9, 1995, with attachment. ACC: MOL.19990319.0341

103492 DOE (U.S. Department of Energy) 1985. An Evaluation of Commercial Repository Capacity for the Disposal of Defense High-Level Waste. DOE/DP/0020/1. Washington, D.C.: U.S. Department of Energy. ACC: MOL.20010730.0387.

132333 DOE 1987. Appendix 2A. Physical Descriptions of LWR Fuel Assemblies. Volume 3 of Characteristics of Spent Fuel, High-Level Waste, and Other Radioactive Wastes Which May Require Long-Term Isolation. DOE/RW-0184. Washington, D.C.: U.S. Department of Energy, Office of Civilian Radioactive Waste Management. ACC: HQX.19880405.0024.

103191 DOE 1994. Final Supplemental Environmental Impact Statement, Defense Waste Processing Facility. DOE/EIS-0082-S. Aiken, South Carolina: U.S. Department of Energy. ACC: MOL.20010730.0383.

171371 DOE 2001. Quality Assurance Audit Report EM-ARC-01-13 of the National Spent Nuclear Fuel Program At Idaho Falls, Idaho. EM-ARC-01-13. [Washington, D.C.]: U.S. Department of Energy. ACC: MOL.20011206.0198.

155970 DOE 2002. Final Environmental Impact Statement for a Geologic Repository for the Disposal of Spent Nuclear Fuel and High-Level Radioactive Waste at Yucca Mountain, Nye County, Nevada. DOE/EIS-0250. Washington, D.C.: U.S. Department of Energy, Office of Civilian Radioactive Waste Management. 
ACC: MOL.20020524.0314; MOL.20020524.0315; MOL.20020524.0316;

MOL.20020524.0317; MOL.20020524.0318; MOL.20020524.0319;

MOL.20020524.0320.

171675 DOE 2002. Quality Assurance Checklist, National Spent Fuel Nuclear Fuel Program. Dates of Evaluation September 23-27, 2002. Activity No.: EM-ARC-02-10.

Washington, D.C.: U.S. Department of Energy, Office of Civilian Radioactive Waste Management:. ACC: MOL.20030303.0018.

158873 DOE 2002. Waste Acceptance System Requirements Document. DOE/RW-0351, Rev. 4. Washington, D.C.: U.S. Department of Energy, Office of Civilian Radioactive Waste Management. ACC: MOL.20020326.0056.

155943 DOE 2002. Yucca Mountain Science and Engineering Report. DOE/RW-0539, Rev. 1. Washington, D.C.: U.S. Department of Energy, Office of Civilian Radioactive Waste Management. ACC: MOL.20020404.0042.

163377 DOE 2003. Source Term Estimates for DOE Spent Nuclear Fuels. DOE/SNF/REP078, Rev. 0. Idaho Falls, Idaho: U.S. Department of Energy, Idaho Operations Office. TIC: 254275.

167367 DOE 2003. Repository Design Asset Functional \& Operational Requirements and Design Solutions. DOE/RW-0600, Rev. 1. Las Vegas, Nevada: U.S. Department of Energy, Office of Civilian Radioactive Waste Management. ACC: DOC.20040202.0005.

171539 DOE 2004. Quality Assurance Requirements and Description. DOE/RW-0333P, Rev. 16. Washington, D.C.: U.S. Department of Energy, Office of Civilian Radioactive Waste Management. ACC: DOC.20040907.0002.

169354 DOE 2004. Source Term Estimates for DOE Spent Nuclear Fuels. DOE/SNF/REP078 Rev. 1. Three volumes. Idaho Falls, Idaho: U.S. Department of Energy, Idaho Operations Office. ACC: MOL.20040524.0451.

164649 EPRI (Electric Power Research Institute) 1999. Determination of the Accuracy of Utility Spent-Fuel Burnup Records. EPRI TR-112054. Palo Alto, California: Electric Power Research Institute. TIC: 254706.

154365 Freeze, G.A.; Brodsky, N.S.; and Swift, P.N. 2001. The Development of Information Catalogued in REV00 of the YMP FEP Database. TDR-WIS-MD-000003 REV 00 ICN 01. Las Vegas, Nevada: Bechtel SAIC Company. ACC: MOL.20010301.0237.

164947 Hamel, W.F. 2003. "Waste Treatment and Immobilization Plant (WTP) High-Level Waste (HLW) Canister Production Estimates to Support Analyses by the Yucca Mountain Project." Memorandum from W.F. Hamel (DOE) to W.J. Taylor, June 26, 2003, with attachment. ACC: MOL.20030828.0080. 
150704 Harris, J.A. and Birch, P. 1987. "The Effects on Topsoil of Storage During Opencast Mining Operations.” Journal of the Science of Food and Agriculture, 40, (3), 220-221. [New York, New York]: Elsevier. TIC: 243316.

106563 Hermann, O.W. and DeHart, M.D. 1998. Validation of SCALE (SAS2H) Isotopic Predictions for BWR Spent Fuel. ORNL/TM-13315. Oak Ridge, Tennessee:

Oak Ridge National Laboratory. TIC: 245042.

131202 Lide, D.R., ed. 1991. CRC Handbook of Chemistry and Physics. 72nd Edition. Boca Raton, Florida: CRC Press. TIC: 3595.

104398 Lytle, J.E. 1995. "Disposal of DOE-owned High Level Waste and Spent Nuclear Fuel.” Memorandum from J.E. Lytle (DOE) to D.A. Dreyfus (DOE/OCRWM), October 26, 1995. ACC: HQO.19951116.0015.

170651 Massie, H.L., Jr. 2004. Reactor Record Uncertainty Determination. 32-5041666-02. Las Vegas, Nevada: Areva. ACC: DOC.20040623.0002.

158051 McKenzie, J.M. 2001. Thermal Data for Naval Nuclear Propulsion Program Spent Nuclear Fuel Canister. Letter from J.M. McKenzie (Department of the Navy) to S.P. Mellington (DOE/YMSCO), August 29, 2001, Ser 08U/01-13933, with enclosure. ACC: MOL.20011029.0285.

163274 NRC (U.S. Nuclear Regulatory Commission) 2003. Yucca Mountain Review Plan, Final Report. NUREG-1804, Rev. 2. Washington, D.C.: U.S. Nuclear Regulatory Commission, Office of Nuclear Material Safety and Safeguards. TIC: 254568.

170912 ORNL (Oak Ridge National Laboratory) 2002. Quality Assurance Plan for the SCALE Computational System. SCALE-QAP-005, Rev. 1. Oak Ridge, Tennessee: Oak Ridge National Laboratory. ACC: MOL.20040708.0340.

103896 Parrington, J.R.; Knox, H.D.; Breneman, S.L.; Baum, E.M.; and Feiner, F. 1996. Nuclides and Isotopes, Chart of the Nuclides. 15th Edition. San Jose, California: General Electric Company and KAPL, Inc. TIC: 233705.

164741 Singh, B. 2002. "Nuclear Data Sheets for A = 79." Nuclear Data Sheets, 96, (1), 1-240. San Diego, California: Elsevier. TIC: 254728.

\subsection{CODES, STANDARDS, REGULATIONS, AND PROCEDURES}

15660510 CFR 63. Energy: Disposal of High-Level Radioactive Wastes in a Geologic Repository at Yucca Mountain, Nevada. Readily available.

16551940 CFR 197. Protection of Environment: Public Health and Environmental Radiation Protection Standards for Yucca Mountain, Nevada. Readily available. 
AP-2.22Q, Rev. 1, ICN 0. Classification Analyses and Maintenance of the Q-List. Washington, D.C.: U.S. Department of Energy, Office of Civilian Radioactive Waste Management. ACC: DOC.20030807.0002.

AP-3.12Q, Rev. 2, ICN 2. Design Calculations and Analyses. Washington, D.C.: U.S. Department of Energy, Office of Civilian Radioactive Waste Management.

ACC: DOC.20040318.0002.

AP-3.15Q, Rev. 4, ICN 4. Managing Technical Product Inputs. Washington, D.C.: U.S. Department of Energy, Office of Civilian Radioactive Waste Management. ACC: DOC.20040510.0004.

AP-SIII.2Q, Rev. 1, ICN 2. Qualification of Unqualified Data. Washington, D.C.: U.S. Department of Energy, Office of Civilian Radioactive Waste Management. ACC: DOC.20040127.0008.

AP-SIII.9Q, Rev. 1, ICN 6. Scientific Analyses. Washington, D.C.: U.S. Department of Energy, Office of Civilian Radioactive Waste Management.

ACC: DOC.20040805.0003.

AP-SV.1Q, Rev. 1, ICN 0. Control of the Electronic Management of Information. Washington, D.C.: U.S. Department of Energy, Office of Civilian Radioactive Waste Management. ACC: DOC.20040308.001.

LP-SI.11Q-BSC, Rev. 0, ICN 0. Software Management. Washington, D.C.: U.S. Department of Energy, Office of Civilian Radioactive Waste Management. ACC: DOC.20040225.0007.

153446 ANSI/ASME NQA-1. 1986. Quality Assurance Program Requirements for Nuclear Facilities. New York, New York: American Society of Mechanical Engineers. TIC: 223750.

103902 ASME NQA-1 1994. Retention of Quality Assurance Records. New York, New York: American Society of Mechanical Engineers. TIC: 223334.

105725 ASTM C 1174-97. 1998. Standard Practice for Prediction of the Long-Term Behavior of Materials, Including Waste Forms, Used in Engineered Barrier Systems (EBS) for Geological Disposal of High-Level Radioactive Waste. West Conshohocken, Pennsylvania: American Society for Testing and Materials. TIC: 246015.

100016 Nuclear Waste Policy Amendments Act of 1987. Public Law No. 100-203, 101 Stat. 1330. Readily available.

\subsection{SOFTWARE CODES}

154059 Software Code: SCALE. V4.3. HP. 30011 V4.3. 
154134 Software Code: SCALE. V4.3 (Addendum). HP. 30011 V4.3 (Addendum).

154394 Software Code: SCALE. V4.4A. HP. 10129-4.4A-00.

\subsection{SOURCE DATA, LISTED BY DATA TRACKING NUMBER}

170760 MO0407SEPFEPLA.000. LA FEP List. Submittal date: 07/20/2004.

\subsection{OUTPUT DATA, LISTED BY DATA TRACKING NUMBER}

SN0310T0505503.004. Initial Radionuclide Inventories for TSPA-LA. Submittal date: $10 / 27 / 2003$.

The DIRS number 168761 was issued for this DTN upon the approval of Rev.00 of this analysis. Neither the DTN nor the data have changed as a result of generating Rev. 01 of this analysis. 
INTENTIONALLY LEFT BLANK 


\section{APPENDIX I \\ NEUTRON-ACTIVATION PRODUCTS OUTSIDE THE SPENT-FUEL MATRIX}


INTENTIONALLY LEFT BLANK 


\section{NEUTRON-ACTIVATION PRODUCTS OUTSIDE THE SPENT-FUEL MATRIX}

This appendix has been taken from Inventory Abstraction (BSC 2001 [DIRS 157575]) with only minor updates and editing.

\section{I.1 PURPOSE}

Most of the radioactivity associated with CSNF assemblies is contained within the spent-fuel matrix. To the extent that the cladding is credited as a barrier to the release of radioactivity, the release of radioactivity from within the cladding is associated with cladding failure. However, during reactor operation, some materials outside the fuel rods become radioactive due to neutron activation. Activation products outside the fuel rods can become available for release after breach of the waste package but long before the bulk of the radionuclide inventory from the fuel matrix is released. Two kinds of materials are candidates for neutron activation: (1) accumulated mineral deposits (crud) on the surface of the cladding that can build up during reactor operation, and (2) assembly hardware (e.g., top and bottom tie plates or nozzles, grid plates, springs, end caps, guide tubes, instrument tubes, or the cladding). The radionuclide inventories that are inputs to this analysis include activation products from the hardware but not from the crud. Activation products from the hardware have been lumped together with the inventory of radionuclides within the fuel matrix in the radionuclide inventory presented in Table 7-1. The purpose of this appendix is to examine the appropriateness of (1) neglecting the radionuclides in the crud and (2) combining the inventory of hardware-activation products in CSNF together with radionuclides in the fuel matrix for repository performance assessment.

\section{I.2 INPUTS}

The data used in this appendix were derived from BSC Design and Engineering calculations that provide radionuclide inventories as a function of time for CSNF assemblies (BSC 2004 [DIRS 171435]; BSC 2004 [DIRS 171436]).

\section{I.3 ACTIVATED MINERAL DEPOSITS (CRUD)}

In addition to the source terms for an assembly based on the irradiated assembly, the activated corrosion products from the coolant deposited on the surfaces of the assembly (crud) are estimated. These surfaces include all the areas of the assembly exposed to the flow of coolant. The composition of the crud is determined by the conditions within the reactor during operation. A number of studies have identified the following radionuclides in PWR (BSC 2004 [DIRS 171435]) and BWR (BSC 2004 [DIRS 171407]) crud: ${ }^{51} \mathrm{Cr},{ }^{54} \mathrm{Mn},{ }^{55} \mathrm{Fe},{ }^{58} \mathrm{Co},{ }^{59} \mathrm{Fe},{ }^{60} \mathrm{Co}$,

${ }^{63} \mathrm{Ni},{ }^{65} \mathrm{Zn}$, and ${ }^{95} \mathrm{Zr}$. These data are based on bounding estimates of surface area and the radionuclide activity density. With the exception of ${ }^{63} \mathrm{Ni}$, these radionuclides need not be considered further because they have half-lives of less than 10 years and become insignificant by the time SNF arrives at the potential repository; they have been screened out on that basis. ${ }^{63} \mathrm{Ni}$, which has a much longer half-life (about 100 years), was screened out by the scenario analyses described in Section 6 of Radionuclide Screening (BSC 2002 [DIRS 160059]). However, because the crud contribution was not included as input to the radionuclide-screening analysis, ${ }^{63} \mathrm{Ni}$ is considered in the crud. It has been estimated that there is no ${ }^{63} \mathrm{Ni}$ in the crud present on BWR fuel (BSC 2004 [DIRS 171407]). The amount of ${ }^{63} \mathrm{Ni}$ present in 30 -year-old PWR crud is 
estimated to be $0.55 \mathrm{Ci}$ (BSC 2004 [DIRS 171435]). The amount of ${ }^{63} \mathrm{Ni}$ in hardware is shown to be much greater. For example, for an average 30 -year-old PWR assembly, $20.5 \mathrm{Ci}$ of ${ }^{63} \mathrm{Ni}$ is calculated for the top-region hardware such as the top nozzle, spring retainer, upper end plug, and upper nuts (BSC 2004 [DIRS 171436]). Thus, the crud would contribute less than 3 percent of the total curies from crud and hardware combined. Therefore, due to the small contribution from crud and the relative short 100-year half-life of ${ }^{63} \mathrm{Ni}$, it is appropriate for the screening analysis in particular and for performance assessment generally to neglect the radionuclides present in SNF crud.

\section{I.4 HARDWARE}

The elements included as constituents of the hardware in BWR and PWR assemblies (BSC 2004 [DIRS 171435]; BSC 2004 [DIRS 171436]), ${ }^{99} \mathrm{Tc}$ and ${ }^{14} \mathrm{C}$, have been screened in and are expected to be present in hardware as neutron activation products. Radionuclides that have been screened out but have half-lives greater than 20 years and are present in the hardware are ${ }^{93} \mathrm{Zr}$, ${ }^{59} \mathrm{Ni},{ }^{63} \mathrm{Ni}$, and ${ }^{94} \mathrm{Nb}$.

The radionuclide-inventory calculations divide the BWR and PWR assemblies into four regions: fuel, bottom, plenum, and top. The calculations preserve the distinction between activation products (called light elements in the computer output) and fission products. The activation products in the bottom, plenum, and top regions originate from hardware because there is no fuel in those regions. In the fuel region, the distinction between activation products from hardware and from constituents of the fuel is not maintained. However, by noting the relative amounts of an element in the hardware and fuel that activates to a radionuclide of interest, it is often possible to determine the primary location of the activation product of interest.

This analysis of activation products in hardware, specifically ${ }^{14} \mathrm{C}$, cites Appendix $2 \mathrm{~A}$. Physical Descriptions of LWR Fuel Assemblies (DOE 1987 [DIRS 132333]) to corroborate data pertaining to the fact that stainless steels such as Stainless Steel Type 304 are present in hardware components. This analysis is not impacted by the technical errors in that DOE report (DOE 1987 [DIRS 132333]).

\section{I.4.1 Technetium-99}

${ }^{99} \mathrm{Tc}$ is an abundant fission product (Parrington et al. 1996 [DIRS 103896]). Therefore, the inventory of ${ }^{99} \mathrm{Tc}$ that is produced as a fission product in the matrix expected to be much greater than the inventory of ${ }^{99} \mathrm{Tc}$ that is produced by hardware activation. However, at least for CSNF and naval fuel, the corrosion-resistant Zircaloy fuel cladding will impede the release of the bulk of the radionuclides from the fuel. For codisposal waste packages, no credit is taken in the TSPA-LA for DSNF cladding (BSC 2003 [DIRS 163693], p. 50).

For CSNF, the amount of radioactivity released shortly after the breach of the waste package depends on the fraction of fuel rods with perforated cladding and the fraction of a perforated fuel rod's radionuclide inventory that can escape. The fraction of fuel rods whose cladding will have failed by the time the waste package is breached depends on the condition of the fuel as emplaced and on repository conditions. Clad Degradation - Summary and Abstraction for LA (BSC 2003 [DIRS 162153], p. 38) estimates the fraction of rods whose cladding will have failed 
by the time the waste package is breached as ranging from 0.01 to 1 percent for Zircaloy rods. To this fraction, the fraction of rods with stainless steel cladding (1.04 percent) is added. The maximum fraction, 2.04 percent will be used in this Appendix for illustrative calculations.

The fast-release fraction of the fission-product inventory for a perforated fuel rod will migrate through cracks and gaps in perforated fuel rods soon after waste-package breach. The recommended fast-release fraction for a perforated rod is given as a triangular distribution between 0.01 and 0.26 (BSC 2004 [DIRS 167321], Table 8.1-1). Illustrative calculations in this appendix will use the value of 0.1 .

The estimated inventory of fission-product ${ }^{99} \mathrm{Tc}$, for the average 25 -year-old PWR assembly is 8.99 Ci (Table 4-16). Because PWR fuels have low concentrations of Mo (BSC 2004 [DIRS 171435]), which activates to ${ }^{99} \mathrm{Tc}$, for the average PWR assembly (Table 4-15), nearly the entire ${ }^{99} \mathrm{Tc}$ activation product in the fuel region originates in the fuel-region hardware. The estimated total neutron-activation inventory of ${ }^{99} \mathrm{Tc}$ for an average 25 -year-old PWR assembly is $1.10 \times 10^{-3} \mathrm{Ci}$ (Table 4-16). This value is an order of magnitude less than the mean fast-release inventory of ${ }^{99} \mathrm{Tc}$ that would be available at that time from fission products upon waste package breach, $0.0204 \times 0.1 \times 8.99 \mathrm{Ci}=1.8 \times 10^{-2} \mathrm{Ci}$. Similarly, for a bounding 5-year-old PWR assembly, the inventory of ${ }^{99} \mathrm{Tc}$ from activation is less than the fission product inventory that would be available from fast release of fission products (Table 4-16). Therefore, combining the CSNF hardware ${ }^{99} \mathrm{Tc}$ with the CSNF matrix ${ }^{99} \mathrm{Tc}$ is a reasonable approximation for TSPA-LA.

\section{I.4.2 Carbon-14}

${ }^{14} \mathrm{C}$ is not produced in appreciable amounts as a fission product (Parrington et al. 1996 [DIRS 103896]). It is produced by activation of nitrogen, carbon, and oxygen in the fuel and hardware (Table 4-15). To judge the relative importance of the three elements as sources of ${ }^{14} \mathrm{C}$, consider the product of the reaction cross-section and the relative abundance (see Parrington et al. 1996 [DIRS 103896], pp. 18 and 19 for the cross-sections and relative abundances). For oxygen, the ${ }^{17} \mathrm{O}$ abundance is 0.04 percent and the thermal $(n, \alpha)$ cross-section is 0.24 barns, yielding $9.6 \times 10^{-5}$ barns per atom. For carbon, the ${ }^{13} \mathrm{C}$ abundance is $1.1 \%$ and the thermal $(\mathrm{n}, \gamma)$ cross section is 1.4 millibarns, yielding $1.5 \times 10^{-5}$ barns per atom. For nitrogen, the ${ }^{14} \mathrm{~N}$ abundance is $99.63 \%$ and the thermal $(\mathrm{n}, \mathrm{p}$ ) cross-section is 1.83 barns, yielding 1.8 barns per atom. Therefore, unless concentrations of oxygen or carbon exceed those of nitrogen by many orders of magnitude, nitrogen is the most important source of ${ }^{14} \mathrm{C}$.

Hardware in the fuel region contains little nitrogen, carbon, and oxygen in comparison to the fuel (BSC 2004 [DIRS 171436]). Therefore, the entire ${ }^{14} \mathrm{C}$ inventory in the fuel region can be considered part of the fuel.

Hardware outside the fuel region does contain elements that activate to ${ }^{14} \mathrm{C}$. Typically, the top and bottom nozzles or tie plates are composed of Stainless Steel Type 304, though other stainless steels are found (DOE 1987 [DIRS 132333], tables throughout labeled "Fuel Assembly Hardware Parts and Materials Report"). The top and bottom tie plates or nozzles account for most of the mass of the top- and bottom-region hardware and contain carbon and nitrogen (BSC 2004 [DIRS 171436]). The Zircaloy components contain some oxygen, but this source of ${ }^{14} \mathrm{C}$ can be neglected because the mass of oxygen is comparable to or less than that of nitrogen 
(BSC 2004 [DIRS 171435]). The plenum springs and the plenum getters are the only other sources of ${ }^{14} \mathrm{C}$ outside the fuel region that are accounted for in the radionuclide inventory calculations (BSC 2004 [DIRS 171436]). The plenum springs and getters are protected by the cladding, so they should be lumped with the fuel for the purposes of this section.

For the average 25-year-old BWR assembly (Table 4-16), ${ }^{14} \mathrm{C}$ in the fuel matrix and the plenum region is approximately five times greater than in the top and bottom hardware $\left(1.40 \times 10^{-1}+\right.$ $\left.4.11 \times 10^{-3}\right) /\left(6.85 \times 10^{-3}+2.44 \times 10^{-2}\right)=4.6$. The ratio of the ${ }^{14} \mathrm{C}$ inventory in the top and bottom hardware to that available by fast release (see Appendix I.4.1) in the fuel region is estimated illustratively for an average BWR assembly as $\left(6.85 \times 10^{-3}+2.44 \times 10^{-2}\right) /\left(1.40 \times 10^{-1}\right.$ $\times 0.0204 \times 0.1)=104.3$ (Table 4-16). Thus, there is much more ${ }^{14} \mathrm{C}$ available from activation of exposed stainless steel components of the hardware than from fast release from the fuel. Similarly, for average PWR and for bounding PWR and BWR assemblies, there is much more ${ }^{14} \mathrm{C}$ available from activation of exposed stainless steel components of the hardware than from fast release from the fuel (Table 4-16).

This observation may seem to require that the ${ }^{14} \mathrm{C}$ from CSNF hardware activation be treated as separate from the fuel matrix. However, ${ }^{14} \mathrm{C}$ from $\mathrm{DSNF}$ will be available soon after waste package breach because the TSPA-LA model does not take credit for the DSNF cladding in codisposal waste packages. In fact, the dissolution of DSNF is conservatively modeled in the TSPA-LA to be instantaneous (BSC 2003 [DIRS 163693], p. 65). Therefore, it is important to consider the ${ }^{14} \mathrm{C}$ contribution from DSNF in codisposal waste packages.

First, consider the fraction of the ${ }^{14} \mathrm{C}$ in $\mathrm{CSNF}$ waste packages that originate from hardware activation. Based on the representative assemblies that were used in the radionuclide inventory calculations, the ratios of top and bottom region inventory to total inventory for BWR and PWR assemblies from Table 4-16 are:

$\left(6.85 \times 10^{-3}+2.44 \times 10^{-2}\right) / 1.75 \times 10^{-1}=0.1786=17.9$ percent for "average" BWR assemblies, and

$\left(2.26 \times 10^{-3}+0\right) / 3.32 \times 10^{-1}=0.00681=0.7$ percent for "average" PWR assemblies.

Similar ratios are obtained for "bounding" assemblies.

$\left(1.23 \times 10^{-2}+4.39 \times 10^{-2}\right) / 3.16 \times 10^{-1}=0.1778=17.8$ percent for "bounding" BWR assemblies;

$\left(3.62 \times 10^{-3}+0.00\right) / 5.35 \times 10^{-1}=0.0668=6.7$ percent for "bounding” PWR assemblies.

The great difference between the BWR and PWR fractions appears because the Babcock and Wilcox PWR assembly used for the inventory calculations has top and bottom nozzles composed of Stainless Steel Type CF3M, which does not contain nitrogen (N) as a constituent of the alloy (BSC 2004 [DIRS 171502]). The top and bottom nozzles or tie plates of most other assemblies (including Westinghouse and Combustion Engineering PWR assemblies and the representative General Electric BWR assembly) are made of Stainless Steel Type 304 (DOE 1987 [DIRS 132333], Fuel Assembly Hardware Parts and Materials Reports throughout), which 
contains N (BSC 2004 [DIRS 171503]). Therefore, the fraction computed for the General Electric BWR assembly is taken to represent CSNF in general. Thus, based on the "bounding" BWR assembly, approximately 18 percent of the ${ }^{14} \mathrm{C}$ inventory for CSNF assemblies originates from hardware activation.

The repository's ${ }^{14} \mathrm{C}$ inventory from CSNF can be estimated as the product of the ${ }^{14} \mathrm{C}$ inventory in a CSNF waste package, $1.37 \mathrm{~g}$ per waste package (Table 7-1); and the number of CSNF + naval waste packages, 7,772 (Table 6-3): $1.1 \times 10^{4} \mathrm{~g}$. The repository's ${ }^{14} \mathrm{C}$ inventory from CSNF hardware is estimated as 18 percent of the total (i.e., $2.0 \times 10^{3} \mathrm{~g}$ ).

Now consider the ${ }^{14} \mathrm{C}$ contribution from DSNF in codisposal waste packages. The amount of ${ }^{14} \mathrm{C}$ available soon after waste package breach from codisposal waste packages is estimated to be 3,412 waste packages (Table 6-3) times $1.78 \mathrm{~g}$ per waste package from DSNF (Table 7-1): $6.1 \times 10^{3} \mathrm{~g}$.

Because the amount of ${ }^{14} \mathrm{C}$ available from CSNF hardware $\left(2.0 \times 10^{3} \mathrm{~g}\right)$ is similar to that available from codisposal waste packages $\left(6.1 \times 10^{3} \mathrm{~g}\right)$, the consequence of combining hardware and fuel-matrix contributions is less benign than it is for ${ }^{99} \mathrm{Tc}$. As modeled in the TSPA-LA the early release from ${ }^{14} \mathrm{C}$ is proportional to the contribution from codisposal waste packages plus the fast release contribution from CSNF waste packages $\left(0.0204 \times 0.1 \times 1.1 \times 10^{4} \mathrm{~g}=22 \mathrm{~g}\right)$ : $6.1 \times 10^{3} \mathrm{~g}+22 \mathrm{~g} \cong 6.1 \times 10^{3} \mathrm{~g}$. Note that combining the ${ }^{14} \mathrm{C}$ from CSNF hardware with the fuel and applying protective effect of the cladding effectively removes ${ }^{14} \mathrm{C}$ due to $\mathrm{CSNF}$ from consideration.

A more realistic model would allow the portion of the ${ }^{14} \mathrm{C}$ inventory that is contained in the hardware to be released independent of the failure of the cladding. Depending on the degradation rate of the material containing the ${ }^{14} \mathrm{C}$, hardware degradation could be a significant contributor to the early release of ${ }^{14} \mathrm{C}$. At one extreme, hardware inventory could be released soon after breach of the waste package so that it would be available at roughly the same time as the fast-release inventory from the spent fuel. This would yield an early release roughly proportional to $6.1 \times 10^{3} \mathrm{~g}+2.0 \times 10^{3} \mathrm{~g}=8.1 \times 10^{3} \mathrm{~g}$. The ratio of the early release contributions from the two approaches $\left(8.1 \times 10^{3} \mathrm{~g} / 6.1 \times 10^{3} \mathrm{~g}\right)$ is a rough correction factor for early releases due to ${ }^{14} \mathrm{C}$ equal to about 1.3 . Thus, combining the inventory of ${ }^{14} \mathrm{C}$ from CSNF hardware-activation products together with the ${ }^{14} \mathrm{C}$ in the $\mathrm{CSNF}$ matrix may cause a slight underestimate in the early release of ${ }^{14} \mathrm{C}$. With time, more and more of the ${ }^{14} \mathrm{C}$ from the fuel matrix would be released, so the magnitude of the underestimate would diminish with time.

Although ${ }^{14} \mathrm{C}$ is not one of the primary contributors to general dose rate in the TSPA-SR model (CRWMS M\&O 2000 [DIRS 153246], Figure 6.1-8), it is first among the lesser contributors before 20,000 years (CRWMS M\&O 2000 [DIRS 153246], Figure 4.1-7). As shown by Figure 6.1-7 of Total System Performance Assessment for the Site Recommendation (CRWMS M\&O 2000 [DIRS 153246]), ${ }^{14} \mathrm{C}$, along with ${ }^{99} \mathrm{Tc}$, is an important contributor to the dose from photon- and beta-emitting radionuclides in groundwater shortly after the end of the 10,000-year regulatory period. Although the TSPA-SR document has been canceled as the project has moved closer to the License Application and preparation of TSPA-LA, these cited statements are appropriate for the use intended here due to the reliability of the source. Due to the importance of ${ }^{14} \mathrm{C}$ to the early dose and the moderate significance of the ${ }^{14} \mathrm{C}$ contribution 
from CSNF hardware, this analysis concludes that the ${ }^{14} \mathrm{C}$ from hardware should not be lumped with the ${ }^{14} \mathrm{C}$ for the fuel matrix in the TSPA-LA.

\section{I.4.3 Zirconium-93}

${ }^{93} \mathrm{Zr}$ is produced by activation of ${ }^{92} \mathrm{Zr}$ (Table 4-15), which is a constituent of Zircaloy components, most notably the cladding, and is not present in other hardware (BSC 2004 [DIRS 171502]; BSC 2004 [DIRS 171503]). Because Zircaloy is very resistant to corrosion under repository conditions (BSC 2003 [DIRS 168795], Appendix II), significant release of ${ }^{93} \mathrm{Zr}$ will be delayed well beyond waste package breach. Moreover, ${ }^{93} \mathrm{Zr}$ has been screened out as a potential contributor to TSPA-LA dose calculations (BSC 2002 [DIRS 160059], Table 13). Therefore, the ${ }^{93} \mathrm{Zr}$ produced by hardware activation can be neglected in assessing repository performance.

\section{I.4.4 Nickel-59, Nickel-63, and Niobium-94}

${ }^{59} \mathrm{Ni},{ }^{63} \mathrm{Ni}$, and ${ }^{94} \mathrm{Nb}$ are not produced in appreciable amounts as fission products (Parrington et al. 1996 [DIRS 103896]). They are produced by activation of $\mathrm{Ni}$ and $\mathrm{Nb}$ in hardware (Table 4-15). Some of the ${ }^{59} \mathrm{Ni},{ }^{63} \mathrm{Ni}$, and ${ }^{94} \mathrm{Nb}$ will originate in Inconel components. Because Inconel, like Zircaloy, is very corrosion resistant, the release of some fraction of the ${ }^{59} \mathrm{Ni},{ }^{63} \mathrm{Ni}$, and ${ }^{94} \mathrm{Nb}$ would be delayed well beyond waste package breach and should not be treated as available upon waste package breach. ${ }^{59} \mathrm{Ni},{ }^{63} \mathrm{Ni}$, and even ${ }^{94} \mathrm{Nb}$ are also found in stainless steel components, which would degrade more quickly than Inconel would and release the radionuclides sooner. However, because ${ }^{59} \mathrm{Ni},{ }^{63} \mathrm{Ni}$, and ${ }^{94} \mathrm{Nb}$ have been screened out by the inventory screening analysis (BSC 2002 [DIRS 160059], Table 13), they can be neglected in assessing repository performance.

\section{I.5 CONCLUSION}

Radionuclide contributions from the crud on CSNF assemblies were screened out based on the methodology used in the screening analysis performed in Radionuclide Screening (BSC 2002 [DIRS 160059]. Further analysis here based on current assessment of CSNF (BSC 2004 [DIRS 171407]) shows that radionuclides in the crud can be neglected in TSPA-LA dose calculations.

A negligible fraction of the ${ }^{99} \mathrm{Tc}$ in CSNF originates from neutron activation of hardware. The inventories of ${ }^{99} \mathrm{Tc}$ from CSNF hardware-activation products and from the CSNF matrix have been combined for TSPA-LA calculations.

Approximately 18 percent of the ${ }^{14} \mathrm{C}$ inventory in CSNF originates from neutron activation of stainless steel hardware outside the fuel rods. Combining the inventory of ${ }^{14} \mathrm{C}$ from CSNF hardware-activation products together with the ${ }^{14} \mathrm{C}$ in the $\mathrm{CSNF}$ matrix is a nonconservative approximation for repository performance assessment. It is recommended that TSPA analysts consider the importance of treating the ${ }^{14} \mathrm{C}$ in the hardware separately. 


\section{APPENDIX II}

DESCRIPTION OF FILES ON CD 
INTENTIONALLY LEFT BLANK 


\section{DESCRIPTION OF FILES ON CD}

The Appendix III CD contains the 687kb workbook: inv_rev1.xls dated 10/31/2003. Information was added to this workbook on 6/23/2004. Note workbooks and worksheets are shown in Courier font throughout the report.

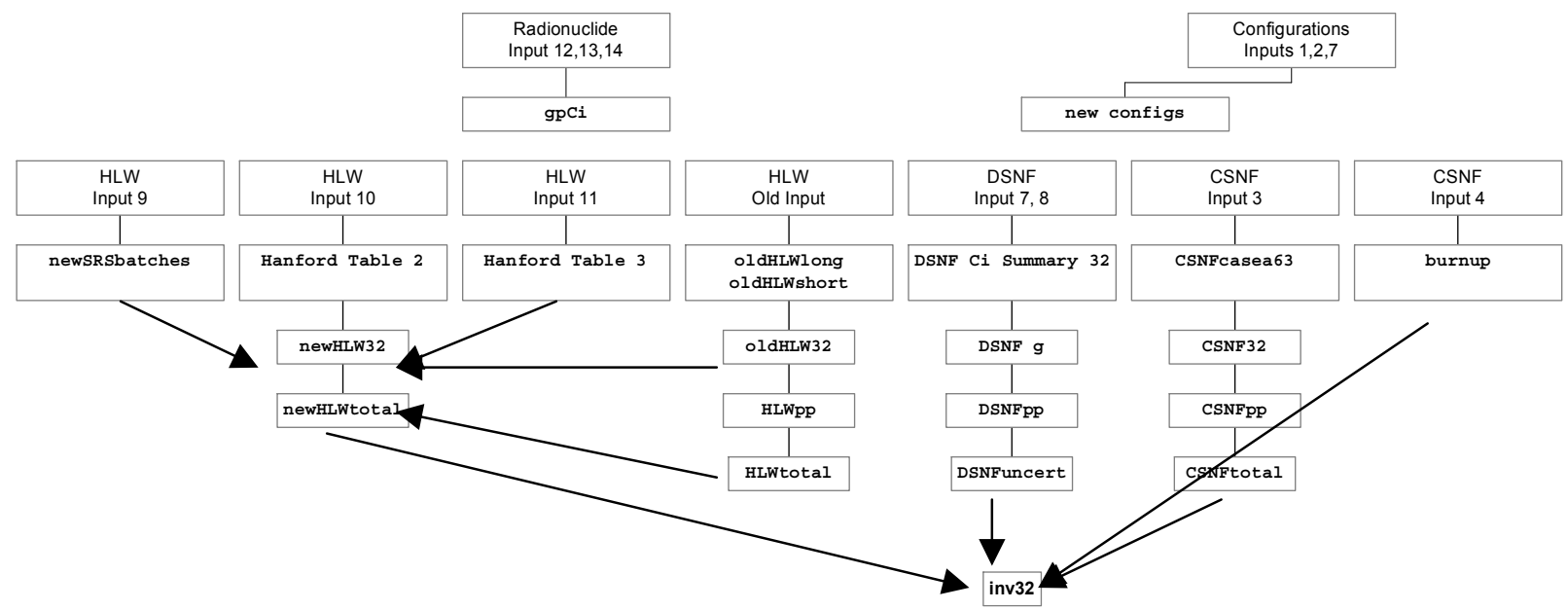

Figure II-1. Flow of Information Between Worksheets in Excel Workbook inv_rev1.xls

The following sections describe the arithmetic operations and calculations performed in this analysis and the content of the Excel worksheets that contain the data in these files. The data is provided on a CD, which is Appendix III. Figure II-1 shows flow of the calculations and information in between the worksheets in inv_revi.xls. Arithmetic operations are also shown on the Excel worksheets. The cumulative list of worksheet files and plot files that can be found on the Appendix III CD is provided in III.1.

\section{II.1 GENERAL INFORMATION SHEETS IN INV_REV1.XLS}

Configurations, new configs, gpCi

The information discussed in Sections 6.1 and 6.2 and presented in Table 4-2 is presented in Microsoft Excel worksheets configurations, new configs and charted in Chart config. Information in Table 4-3 is found in gpCi.

gpCi (grams per curie)

Using Equation II- 1 , the mass per activity $\left(\mathrm{m}_{\mathrm{i}} / \mathrm{a}_{\mathrm{i}}\right)$ in $\mathrm{g} / \mathrm{Ci}$ for each of 32 radionuclides (i) are calculated using constants by Parrington et al. (1996 [DIRS 103896]): half-lives in years $\left(\mathrm{t}_{\mathrm{i}}\right)$, pp. 18 to 50; Avogadro's constant $\left(\mathrm{N}_{\mathrm{A}}\right)$, p. $59 ; 3.7 \times 10^{10} \mathrm{~Bq} / \mathrm{Ci}$, p. 58; and 31,556,930 sec/yr, p. 55. 
The latest half-life for ${ }^{79} \mathrm{Se}$ was taken from nuclear data sheets by Singh (2002 [DIRS 164741]). The molecular weights $\left(\mathrm{MW}_{\mathrm{i}}\right)$ in $\mathrm{g} / \mathrm{mol}$ were taken from the radionuclide names because that value had enough significant figures for these purposes:

$$
\frac{\mathrm{m}_{\mathrm{i}}(\mathrm{g} / \mathrm{Ci})}{\mathrm{a}}=\frac{3.7 \times 10^{10} \mathrm{~Bq} / \mathrm{Ci} \times 31,556,930 \mathrm{sec} / \mathrm{yr} \times \mathrm{MW}_{\mathrm{i}} \times \mathrm{t}_{\mathrm{i}}}{\ln (2) \times \mathrm{N}_{\mathrm{a}}}
$$

\section{II.2 CSNF SHEETS:}

a63, CSNFcasea63, CSNF32, CSNFpp, CSNFtotal, burnup, burnup recalc, config variability

The average CSNF radionuclide and curie per assembly data for the year 2033 (CRWMS M\&O 2000 [DIRS 138239]) were transposed into columns of sheet CSNFcasea63.

Sheet CSNF32 collected the information for the 32 isotopes of interest from the 61 radionuclides in CSNFCasea63. Next, the curies were converted to grams by multiplying by the $\mathrm{g} / \mathrm{Ci}$ for each radionuclide from gpCi. To prevent errors when plotting zero grams in log-space, a cutoff of $1 \times$ $10^{-6}$ was imposed.

The worksheet CSNFpp (pp stands for per package) takes the per assembly inventories in grams from CSNF32 and multiples by the number of assemblies per package for the configuration. The number of assemblies per package is taken from new configs. The data is repeated with a $1 \times$ $10^{-6}$ cutoff for log plotting. The weighted average of the five configurations is provided in column N, but calculated in column Q of CSNFtotal, which is discussed below.

The worksheet CSNFtotal calculates the total grams for each waste type for each configuration by multiplying the per package values from CSNFpp by the number of packages in that configuration. The configuration is listed in row 2; the number of packages for each configuration is listed in row 3 as taken from configurations. The grand total for the appropriate CSNF package type is calculated in column G by summing the values in columns B through $\mathrm{F}$. The weighted average is calculated in column $\mathrm{H}$ as the grand total divided by the total number of CSNF packages. This information is repeated with a $1 \times 10^{-6}$ cutoff for log-plotting. The weighted average, $i$, is carried forward to inv32 for use in TSPA-LA.

To estimate uncertainty in the weighted average in inv32, the burnups were examined in worksheet burnup. Weighted average burnups were calculated for the three 1999 waste stream "arrival scenarios" (CRWMS M\&O 2000 [DIRS 138239]) and the four 2002 "arrival scenarios" (BSC 2003 [DIRS 165990], Tables 2 and 4). The calculated weighted average burnups were then compared to the nominal base for use in Section 6.6.1. The data in sheet: burnup recalc compares two methods of determining the uncertainty factors; one based on the number of packages associated with a given burnup and the other uses the MTU. The results are the same for the two methods.

Sheet config variability is the data used to graph Figure 6-6, which shows the ratios of CSNF configuration inventories to the CSNF weighted average. 


\section{II.3 HLW SHEETS:}

oldHLWlong, oldHLWshort, oldHLW32, newSRSbatches, Hanford table 3, Hanford table 2, HLWpp, HLWtotal, newHLW32, new HLW total

Inventory Abstraction (BSC 2001 [DIRS 157575]) data was repeated here before new information was made available. This old information has been kept in this document in order to examine the volatility of the projected radionuclide inventory estimates. The old calculations are presented first.

The HLW radionuclide and curie per canister data for the year 2040 in Tables 6-1 and 6-2 of Source Terms for HLW Glass Canisters (CRWMS M\&O 2000 [DIRS 151947]) were cut and pasted into sheets oldHLWshort and oldHLWlong, respectively. From these, the relevant data was collected into convenient format in sheet oldHLW32 columns. Columns L through P of oldHLW32 performed two tasks: they summarized the short glass canister inventory into minimum, maximum and average, and converted curies to grams.

During production of this analysis, the codisposal configurations were changed from those in Table 4-2 to those in Table 6-3. Sheets HLWpp and HLWtotal were done for the first set of configurations, and new HLW total was used for the new set of configurations (new calculations described below).

The worksheet HLWpp takes the per-canister inventories in grams from oldHLW32 and multiplies by the number of cans per package for the configuration. The number of canisters per package is taken from configurations and listed in row 4 (columns B-F). The weighted average of the 5 configurations is provided in column $\mathrm{N}$ that is linked to column $\mathrm{Q}$ of HLWtotal where it is calculated. The worksheet HLWtotal calculates the total grams for each waste type for each configuration by multiplying the per package values from HLWpp by the number of packages in that configuration. The configuration is listed in row 3; the number of packages for each configuration is listed in row 4 as taken from configurations. The grand total for the codisposal package type is calculated in column $\mathrm{G}$ by summing the values in columns $\mathrm{B}$ through $\mathrm{F}$ (configurations 1 through 5 for CSNF). The weighted average is calculated in column $\mathrm{H}$ as the grand total divided by the total number of CSNF packages. This information is repeated in columns with a $1 \times 10^{-6}$ cutoff for easy log plotting.

The new calculations start with newSRSbatches (Allison 2004 [DIRS 168734] and Hanford table 2 (Hamel 2003 [DIRS 164947]), where curies per SRS batch and curies for all of Hanford for the year 2030, were collected and converted to curies per canister. Data shown in newSRSbatches continues to the right with comparisons of the curies in the old short canisters and with preparations for plotting Figure 6-11. Data in newHLW32 converts the curies per canister to grams per canister for the two sets of HLW glass data and compares the new to old calculations. The data was prepared for plotting Figure 6-10. The file: newHLWtotal calculated the weighted average based on the new number of canisters in new configs. It also prepares and plots the old and new HLW weighted averages. Hanford table 3 is used to develop the uncertainty distribution as discussed in Section 6.6.3. 


\section{II.4 DSNF SHEETS}

The following is a list of data worksheets for the DSNF analysis: DSNF Ci summary 32, DSNF $g$, DSNFpp, DSNF uncert, Chart DSNF uncert, DSNF Ci summary 32 new, DSNF $g(2)$, DSNFpp.

The following is a list of plot files for DSNF: chart total, chart gpp, inv32 for plotting, inv32.

The following is a list of plot files comparing the 2003 DSNF data with the 2004 data:

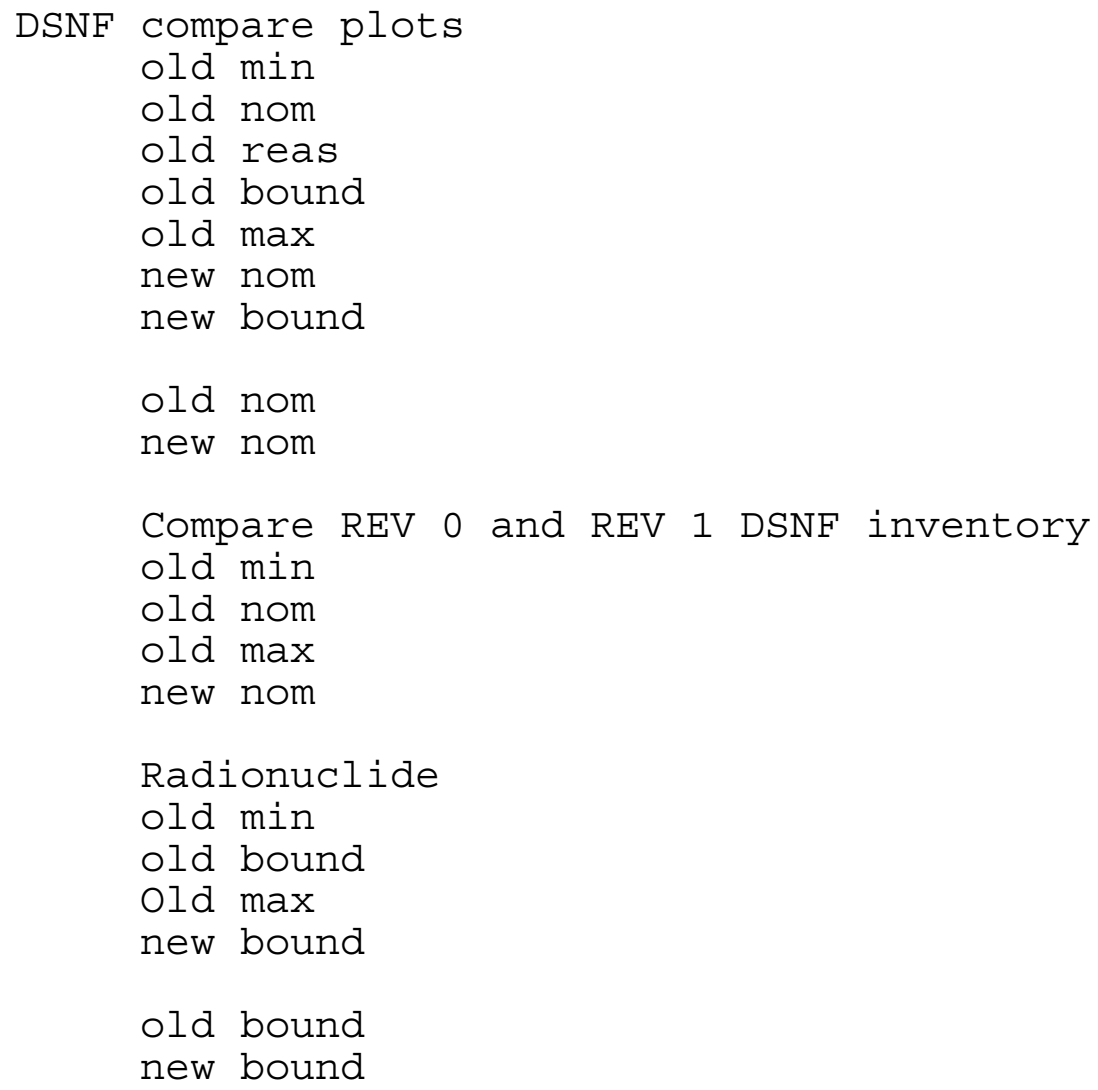

DSNF Ci summary 32 collected information from the first eight worksheets of "Total 2030 D568-585.xls" file from the NSNFP report REP-078 (DOE 2003 [DIRS 163377]) for the 32 isotopes of interest. DSNF $g$ converts the curies to grams, and adds a column for the "base case" which contains all wastes except the bare assemblies. DSNFpp converts the total grams to grams per package and DSNF uncert computes the ratio of the maximum to the nominal value for each isotope.

This analysis uses, as a basis for DSNF wastes, a second set of DSNF files created to compare radionuclide inventory data provided by Revisions 0 and 1 of Source Term Estimates for DOE Spent Nuclear Fuels (DOE 2003 [DIRS 163377]; DOE 2004 [DIRS 169354]). The new files parallel the content and the calculations in the same way as the original files using Rev. 0 of the referenced report. 
Therefore, DSNF Ci summary 32 new collected information from the first eight worksheets of "Summary_2030.xls" file from Source Term Estimates for DOE Spent Nuclear Fuels (DOE 2004 [DIRS 169354]) for the 32 isotopes of interest. DSNF $g$ (2) converts the curies to grams and adds a column for the "base case," which contains all wastes except the bare assemblies. DSNFpp (2) converts the total grams to grams per package and DSNF uncert (which is the same as the same uncertainty is applied to the new data) computes the ratio of, in this case, the bounding instead of maximum, to the nominal value for each isotope. Columns "new nom" and "new bound" from worksheet DSNF uncert are used to create the plots presented in Section 6.6.2 comparing the radionuclide inventory from the 2004 data with the 2003 data used in this analysis to prepare the radionuclide inventory for TSPA-LA.

\section{II.5 TSPA-LA INVENTORY SHEETS}

Inv32, inv32 for plotting, Chart total, and Chart gpp

The worksheet inv 32 collects the weighted average grams per package for the 32 radionuclides for the three waste types into a single sheet. Note that the inventory reported is for various dates: CSNF 2033, DSNF 2030, and HLW 2030 respectively. The number of CSNF and codisposal waste packages is listed at the top of the columns. Note that there are 7,472 CSNF waste packages, but the addition of 300 naval waste packages that will be treated as CSNF waste packages in the TSPA-LA, increases the total as listed to 7,772. inv32 for plotting, Chart total, and Chart gpp were included for plotting purposes. 
INTENTIONALLY LEFT BLANK 


\section{APPENDIX III}

WORKSHEETS AND PLOTS IN INV REV1. XLS 
INTENTIONALLY LEFT BLANK 


\section{WORKSHEETS AND PLOTS IN INV_REV1.XLS}

The following worksheets and plot files are in workbook inv_rev1.xls on the CD. The use and content of these is described in Appendix II and in the analysis.

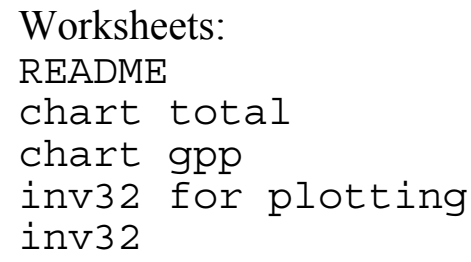

Plot files:

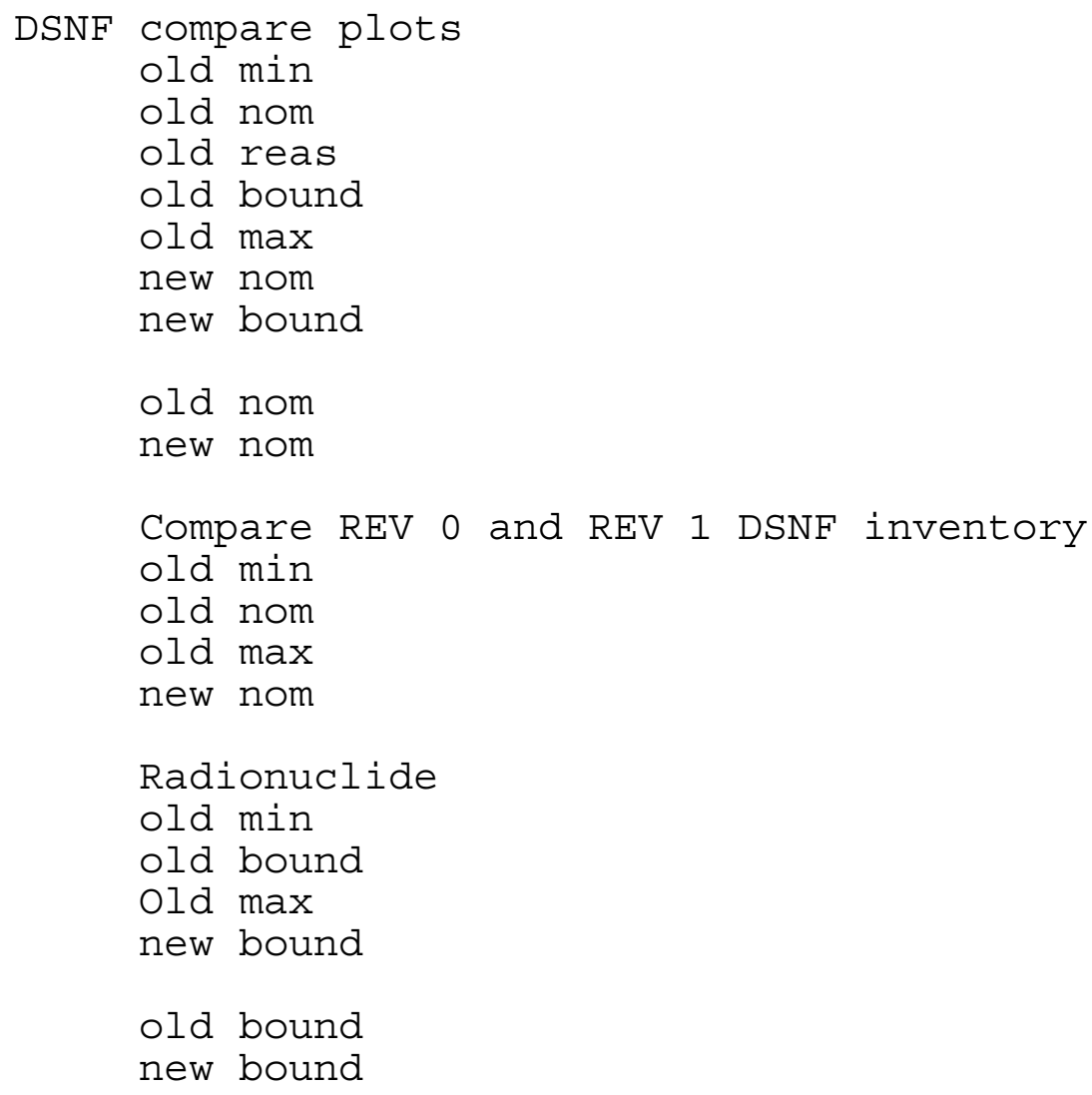

Worksheets:

DSNF uncert

DSNFpp (2)

DSNFpp

DSNF $g$ (2)

DSNF $g$

DSNF Ci summary 32

DSNF Ci summary 32 new

new HLW total

newHLW3 2

HLWtotal

HLWpp

Hanford table 2 


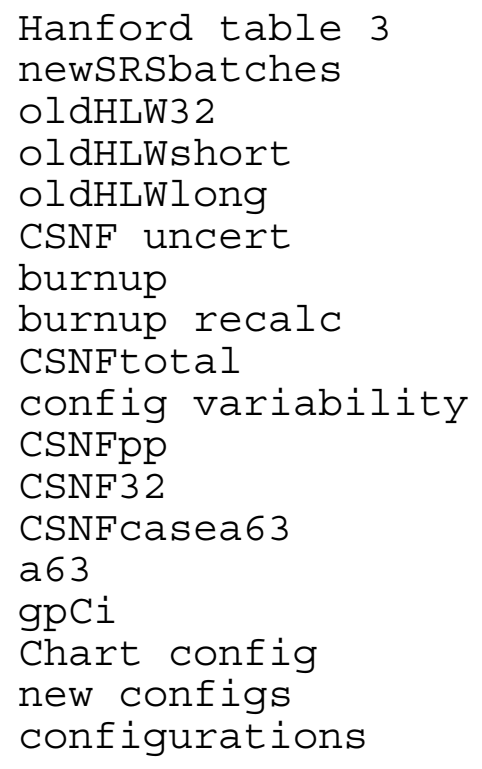




\section{APPENDIX IV \\ QUALIFICATION OF UNQUALIFIED DATA USED AS DIRECT INPUTS}


INTENTIONALLY LEFT BLANK 


\section{QUALIFICATION OF UNQUALIFIED DATA USED AS DIRECT INPUTS}

Data from references used as direct input to this analysis must meet the definition of "qualified" in accordance with AP-3.15Q, Managing Technical Product Inputs. Input data that does not meet the definition "qualified" data require qualification in accordance with AP-SIII.9Q, Scientific Analyses, Section 5.5.1 k-m, requirements. Where "data is obtained from outside sources that are not established facts," the data must be "demonstrated to be suitable for the specific application. When appropriately justified these data are considered qualified for use within the technical product." This data qualification is intended to provide the desired level of confidence that the data are suitable for their intended use and the intended use is only for this analysis. AP-SIII.9Q, Section 5.2.1-1 states, "The extent to which the data demonstrate the properties of interest shall be addressed. One or more of the following factors shall be used when presenting the case that the data are suitable for intended use:"

- Reliability of data source

- Qualification of personnel or organizations generating the data

- Prior uses of the data

- Availability of corroborating data.

Data from the following sources are qualified for intended use in accordance with the above factors in AP-SIII.9Q:

IV.1. "Projected Glass Composition and Curie Content of Canisters from the Savannah River Site (U)" (Allison 2004 [DIRS 168734], Appendix 1 (Fowler report, Rev.2))

IV.2. "Waste Treatment and Immobilization Plant (WTP) High-Level Waste (HLW) Canister Production Estimates to Support Analyses by the Yucca Mountain Project" (Hamel 2003 [DIRS 164947])

IV.3. Validation of SCALE (SASH2H) Isotopic Predictions for BWR Spent Fuel (Hermann and DeHart 1998 [DIRS 106563]); An Extension of the Validation of SCALE (SASH2H) Isotopic Predictions for PWR Spent Fuel (DeHart and Hermann 1996 [DIRS 156084])

IV.4. Source Term Estimates for DOE Spent Nuclear Fuels (DOE 2004 [DIRS 163377]; Source Term Estimates for DOE Spent Nuclear Fuels (DOE 2004 [DIRS 169354]).

For data not derived from external sources, AP-SIII.2Q, Qualification of Unqualified Data, has been used for data qualification. Inputs qualified in accordance with AP-SIII.2Q require a Data Qualification Plan and use of one or a combination of methods identified in Attachment 3 of AP-SIII.2Q. These plans are provided in this appendix along with the results of the data qualification task. The data to be qualified in accordance with AP-SIII.2Q are from the following reference sources:

IV.5 2002 Waste Stream Projections Report (BSC 2003 [DIRS 165990]). 


\section{IV.1 Qualification of Data from Allison 2004 ( [DIRS 168734], Attachment I, Addendum I: Projected Glass Composition and Curie Content of Canister from the Savannah River Site (U)}

The following data qualification was performed in accordance with AP-SIII.9Q, Scientific Analyses, Section 5.2.11. The following factors have been used to show that data are suitable for intended use:

- Reliability of data source

- Qualification of personnel or organizations generating the data

- Extent to which the data demonstrate the properties of interest

- Prior uses of the data.

The data used in this analysis is from a report by J.R. Fowler, Projected Glass Composition and Curie Content of Canister from the Savannah River Site (U) attached as a memorandum from J. M. Allison, Manager, Department of Energy (DOE) Savannah River Operations Office (SR), to John Arthur III, Deputy Director, Office of Civilian Radioactive Waste Management, Las Vegas, NV (Allison 2004 [DIRS 168734], Attachment I and Appendix I). This report is the source of input data for Savannah River DHLW glass. The memorandum has been attached to this report.

The memorandum states that these data have been reviewed and determined by the Deputy Director, Office of Civilian Radioactive Waste Management (OCRWM) as technically adequate and referenceable information on HLW glass. It has been determined that the use of these data are appropriate for this analysis and characterization of the radionuclide inventory for HLW forms/glass for the SRS. The memorandum included in this qualification notes that the Westinghouse Savannah River Company endorses the report demonstrating the reliability of the source.

The data used in this analysis includes: the HLW radionuclide inventory and their source terms (i.e., curies per canister, and the number of canisters for each "batch(es).)" These data are shown in Table 4-9 "New Estimated Curies Per Canister for the Savannah River Site (SRS), HLW (Batches 1A, 1B, 2\&3, 4-10" of this analysis. The data are found in the Appendix 1 of the source document (Allison 2004 [DIRS 168734]): Tables 5-8 corresponding to "Decay of SRS Sludge Batches 1A, 1B, 2\&3, 7 and 4-10," the corresponding number of canisters identified as needed to contain the HLW in that "batch" where the curies per canister are decayed to the year 2030 (i.e., the projected year of emplacement of these wastes). The data are appropriate for the type of data under consideration and demonstrate the properties of interest. The properties of interest include the HLW radionuclide inventory in curies, the number of canisters projected as necessary for disposal of these wastes, and the curie levels projected to the year of projected emplacement of these wastes (currently 2030). These specific data are needed in order to produce the necessary input to TSPA-LA and, therefore, the data are considered qualified for intended use in that they demonstrate the properties of interest.

Any comprehensive characterization of the inventory of radionuclides planned for geologic disposal must include HLW forms. Westinghouse Savannah River Company (WSRC) is the DOE contractor responsible for HLW form production and the Savannah River Defense Waste 
Processing Facility (DWPF) processes such waste for disposal. Having been informally reviewed (by John Arthur III) and concluded (by him) to be technically adequate for (the programs) needs, the WSRC "has endorsed the report and formally entered it into their document control system and is submitting the report to the Office of Science and Technical Information."

Attachment I to the memorandum states the appended (Fowler) report "was prepared by WSRC to provide referenceable information on SRS HLW forms planned for geologic disposal (Allison 2004 [DIRS 168734]). The radiological data requested by DOE OCRWM and will be used in preparation of the preclosure and postclosure safety analyses for the Yucca Mountain Project (YMP) and License Application." This attachment also states that "a design check of Appendix I (the Fowler report) has been performed by WSRC in accordance with the SRS procedure for design verification and checking" and "this design check is documented by signature of the reviewer on the Appendix 1 document" (Allison 2004 [DIRS 168734]).

It was also determined that the data cited were obtained from testing and analyses conducted at the Westinghouse Savannah under the requirements of ASME NQA-1 [DIRS 103902], Retention of Quality Assurance Records. This was confirmed by discussions with Joe Yanek, QA Manager for the Savannah River Site, where the analyses of the sludges were made. An NQA-1 quality assurance (ASME NQA-1 [DIRS 103902]) is a nuclear quality assurance program instituted by many DOE-contracted facilities and consists of 18 criteria that are the basis of the QARD that defines the quality assurance for the Yucca Mountain project. It contains requirements for the qualification of personnel for the work they do, the calibration of measuring and test equipment, requirements for the content and retention of records to name a few.

The qualification team contacted the Savannah River site quality assurance manager, Mr. Joe Yanek, who confirmed the subject report was contracted out by the Westinghouse Savannah River Company. The author of the report, John R. Fowler, researched and collected data from existing documentation and reports containing analytical results from testing the composition of HLW glass and curie content of canisters based on these measured values and projections. The "updated data in this report are based on either actual production of waste glass or the remaining high-level waste inventory stored at the SRS. Accordingly, the radiological content for the various glasses described provide actual concentrations for canisters already produced into a reasonable and realistic estimate for future production of SRS canisters" (Allison 2004 [DIRS 168734], Appendix 1, p.5).

With respect to the analytical data in the Fowler report that characterized the sludge and waste forms, it was determined through interviews with the QA Manager of Westinghouse SRS, Joe Yanek, that Westinghouse SRS has had an NQA-1 Quality Assurance Program for many years. Mr. Yanek confirmed that one of the authors/co-authors (N.E. Bibler) of a referenced report providing analytical data on DWPF glass and sludge samples was known to him and that the laboratory analyses performed by Mr. Bibler would have been conducted under an NQA-1 QA program. Such a program would be equivalent to the QA program that BSC is currently under. Therefore, based on this information, these data may be considered qualified for intended use based on qualification of personnel or organizations generating the data.

As noted in this report, the inventory data needed is for projections of the curie levels at the year of projected emplacement. For HLW glass, this is currently 2030. The report notes that the 
values provided are bounding numbers and that, "the exact number of canisters to be produced in the future is, as always, uncertain." The Fowler report states that the number of canisters from future production estimates is based on a 2002 forecast used by many within the DOE complex. Therefore, based on this information, the data used from this source is qualified for intended use based on prior uses of the data.

The fact that the curie content and the number of canisters is formulated to be bounding "using estimates based on actual canister production and current waste inventories" and, therefore, "they more accurately reflect the expected curie content and isotopic mix of DWPF glass canisters than the curie content" the data used from this source meets data requirements for this analysis. In light of the fact that the data from sludge analyses is reported in a current report (Fowler report is dated 1/6/04), and these data have been reviewed and determined by the Deputy Director, OCRWM as "technically adequate and referenceable information" on HLW glass, it has been determined that the use of these data are appropriate for this analysis and characterization of the radionuclide inventory for HLW forms or glass for the SRS.

These data are combined with the HLW data obtained from Hanford (Hamel 2003 [DIRS 164947]). Uncertainty values are derived to show the range of values reported. The Fowler report states that the SRS production of canisters for HLW glass and the storage and filling of canisters is conducted in accordance with the environmental impact statements for the DWPF, such as Final Supplemental Environmental Impact Statement, Defense Waste Processing Facility (DOE 1994 [DIRS 103191].

Conclusion: Based on the information obtained and examined (and noted in this report), the data used from the referenced document (Allison 2004 [DIRS 168734]) meets the data qualification requirements in accordance with AP-SIII.9Q, and as such, provides the desired level of confidence that the data are suitable for intended use. The intended use is only for this work product. Therefore, no action is required under AP-SIII.3Q, Submittal and Incorporation of Data to the Technical Data Management System. However, the data and its source have been identified in the document input reference system under AP-3.15Q, Managing Technical Product Inputs. 


\section{BSC CORRESPONDENCE LOG \#0303040661}

DOE F 1325:8 (Res |1.12-91)

United States Government

\section{memorandum}

DATE:

FE\& 262004

REPLY TO

ATTN OF:

WDED (T. L. Montgomery, 803-208-8565)
MOL.20040317.0265 QA: N/A

Department of Energy (DOE)

Savannah River Operations Office (SR)

RECEIVED BY BSC CCU

DATE: 03/03/2004

\section{SUBJECT: Inventories in Support of Preparation of the Yucca Mountain Project License Application (Your letter, JCP-0445, 1/28/04)}

To: John Arthur, II, Deputy Director, Office of Civilian Radioactive Waste Management, Las Vegas, NV

In response to your request for referenceable information on HLW glass, I am providing a report titled "Projected Glass Composition and Curie Content of Canisters from the Savannah River Site (SRS) (U)." Based on your informal review of this information, you previously concluded that it is technically adequate for your needs. The Westinghouse Savannah River Company, the contractor responsible for HLW Form Production at the SR Defense Waste Processing Facility, has endorsed the report and formally entered it into their document control system and is submitting the report to the Office of Science and Technical Information.

If you have any questions, please contact me or Terry Montgomery, of my staff, at 803-208-8565.

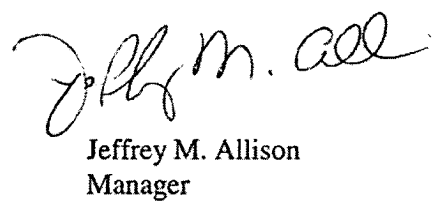

DC-04-019

Attachment:

Report

cc w/attch:

G. Martin, Jr., BSC, Las Vegas, NV

S. E. Gomberg, (RW-20E), HQ 


\section{IV.2 QUALIFICATION OF DATA USED FROM "WASTE TREATMENT IMMOBILIZATION PLANT (WTP) HIGH-LEVEL WASTE (HLW) CANISTER PRODUCTION ESTIMATES TO SUPPORT ANALYSES BY THE YUCCA MOUNTAIN PROJECT" (HAMEL 2003 [DIRS 164947])}

The following data qualification was performed in accordance with AP-SIII.9Q, Scientific Analyses, Section 5.2.11. The following factors have been used to show that data are suitable for intended use:

- Reliability of data source

- Qualification of personnel or organizations generating the data

- Extent to which the data demonstrate the properties of interest

- Prior uses of the data.

The source of the data used in this analysis comes from a memorandum from W.F. Hamel, Director, Waste Treatment Project Engineering \& Commissioning Division of DOE Richland Operations Office, dated June 26 2003. The subject of the memorandum is "Waste Treatment Immobilization Plant (WTP) High-Level Waste (HLW) Canister Production Estimates To Support Analyses By the Yucca Mountain Project." The memorandum has an attached report: "Estimates of Immobilized High-Level Waste (HLW) to be Produced in the Hanford Waste Treatment and Immobilization Plant (WTP)."

The memorandum states that it "transmits estimates of the HLW canister production requirements for the WTP" and that "these estimates have been derived from existing WTP Project information and have been prepared to support analyses by the Office of Civilian Radioactive Waste Management (RW) for the Yucca Mountain Project."

The memorandum describes three Cases that bound the expected range of HLW canisters to be produced in the WTP; the WTP Program Case, the WTP Planning Case, and the WTP Technology Case. A description of these cases is provided in the memorandum with the associated wt \% waste loading. These data in the memorandum along with the data in the attached report are used in this report and are the subject of this data qualification.

The data from the Hamel memo and attached report that are used in this analysis are:

1. The HLW canister production estimates that bound the range of HLW canisters produced in the WTP.

2. The data from Table 1 of this reference summarizing the chemical composition of the HLW glass provided and the associated waste loading wt \% for three cases: WTP program case, the planning case, and the technology case.

3. Table 2, which provides the estimated radioactivity in the HLW canisters at decay dates of which only the data for 2030, and the waste loading percent.

4. The data from Table 3 of this reference entitled: "HLW Canister Production Estimates for Alternative Canister Waste Loading and Canister Fill Levels" providing the percent canister fill levels $(100 \%, 95 \%$ and $87 \%)$, corresponding to the three canister 
fill scenarios, maximum fill case, WTP contract fill case, and minimum fill case; the number of canisters for each case based on fill levels.

5. The wt $\%$ of waste loading corresponding to the three cases from Table 2 of the reference is used to develop uncertainty related to Hanford HLW. The inputs from this reference are shown in Table 4-11.

The estimates of canister production were prepared to support scoping studies to be conducted by DOE Richland Operations Office (RW). It is stated however that these scoping studies were not prepared under Quality Assurance Requirements and Description (DOE 2004 [DIRS 171539]).

This qualification analysis has determined that there is confidence in the data acquisition and development of results; that results are appropriate, reasonable, and suitable for their intended use and the information is transmitted by sources or professionals considered reliable and qualified.

The transmittal letter and report are prepared by an individual (William J. Hamel) prominent in the organization responsible for managing and assessing the production and content of HLW at the Hanford facility in Richland, WA.; he is the Director of the Waste Treatment Project Engineering \& Commissioning Division. The memorandum states that the estimates of HLW canister production are stated to "bound the expected range of HLW canisters to be produced by the Waste Treatment and Immobilization Plant (WTP)." Although the estimates provided were prepared to support "scoping studies that will be conducted by RW" and have not been prepared under Quality Assurance Requirements and Description (DOE 2004 [DIRS 171539]), all three cases are believed to be compliant with the current "Waste Acceptance System Requirements Document" (WASRD) (DOE 2002 [DIRS 158873]). The memorandum states that other DOE organizations within RW will be using these estimates in addition to the fact that the WASRD is a well-known and used requirements document used for planning the management of HLWs.

The data provided in Table 2 of the reference summarizes the radiochemical inventory in curies of the HLW canisters for the decay date of 2030 needed in the analysis report. Table 3 of the reference provides data with respect to canister fill levels for the three cases (A through $\mathrm{C}$ ) that provide bounding estimates on the range of HLW canisters to be produced by the WTP. The memorandum states that: "All three cases result in a HLW form that is believed to be compliant with RW's acceptance requirements identified in "Waste Acceptance System Requirements Document (WASRD)." These data, chemical composition of HLW glass, the total curies per radionuclide for the radionuclides important to dose, and number of canisters for the three cases are intended to bound the range of HLW canisters and content for the year of projected emplacement, 2030. These data are needed for this report under revision by the RIT in order to provide necessary data on the radionuclide inventory to be used as input by TSPA-LA.

Conclusion: This data qualification analysis shows that the data used from the Hamel reference are qualified for intended use. The basis for this conclusion is that both the transmittal letter and the report are prepared by an individual (William J. Hamel) who is prominent in the organization responsible for managing and assessing the production and content of HLW at the Hanford facility in Richland, WA. Moreover, the estimates of HLW canister production are stated to "bound the expected range of HLW canisters to be produced by the Waste Treatment and 
Immobilization Plant (WTP)." Although the estimates provided were prepared to "scoping studies that will be conducted by RW" and have not been prepared under Quality Assurance Requirements and Description (DOE 2004 [DIRS 171539]), all three cases are believed to be compliant with the current "Waste Acceptance System Requirements Document" (WASRD). The fact that other DOE organizations within RW will be using these estimates in addition to the fact that the WASRD is a well known and used requirements document used for planning the management of HLWs, it is believed that the data reported in this reference source is qualified for the intended use in the this report. In addition, the data provided in Table 2 of the reference summarizes the radiochemical inventory in curies of the HLW canisters for the decay date of 2030 needed in the analysis report. Table 3 of the reference provides data with respect to canister fill levels for three fill scenarios (maximum, (100 percent), WTP contract fill (95 percent), and minimum fill case ((87 percent), correlated to the canister production numbers. These data allow uncertainty calculations to be applied to the inventory projected for 2030 .

In addition, the information obtained and examined provides the desired level of confidence that the data used from the subject reference are suitable for intended use, and the intended use is only for this work product. Therefore, no action is required under AP-SIII.3Q, Submittal and Incorporation of Data to the Technical Data Management System. However, the data and their sources have been identified in the Document Input Reference System under AP-3.15Q, Managing Technical Product Inputs.

\section{IV.3 QUALIFICATION OF DATA USED FROM "AN EXTENSION OF THE VALIDATION OF SCALE (SAS2H) ISOTOPIC PREDICTIONS FOR PWR SPENT FUEL" (DEHART AND HERMANN 1996 [DIRS 156084]) AND "VALIDATION OF SCALE (SAS2H) ISOTOPIC PREDICTIONS FOR BWR SPENT FUEL" (HERMANN AND DEHART 1998 [DIRS 106563])}

A data qualification effort has been conducted for the following data used as direct input to this analysis and referenced from the reports:

- Validation of Scale (SAS2H) Isotopic Predictions for BWR Spent Fuel, Hermann, O.W. and DeHart, M.D. 1998. ORNL/TM-13315; Table 24: "Summary of percentage differences between measured and computed composition in this BWR validation study as averages and spreads." Specifically, the minimum and maximum values (spread) associated with the identified BWR radionuclides of interest to TSPA-LA were used in this analysis. The equation used to determine these uncertainties and referenced in the Table 24 is: $($ Calculated/measured -1$) \times 100 \%$. The values from Table 24 are presented in Table 4-7 of this analysis.

- An Extension of the Validation of SCALE (SAS2H) Isotopic Predictions for PWR Spent Fuel, DeHart, M.D. and Hermann, O.W. 1996, ORNL/TM-13317; Table 19: "Summary of percentage differences between measure and computed composition in this study as averages and spreads." Specifically, the minimum and maximum values (spread) associated with the identified PWR radionuclides that are of interest to TSPA-LA were used in this analysis. The equation used to determine these uncertainties (referenced in the Table 24) is: (Calculated/measured -1$) \times 100 \%$. The values from Table 19 are presented in Table 4-7. 
The data from these two sources were used to identify the maximum and minimum correction factors associated with computational methods. When combined with the maximum and minimum projected average burnup ratios developed from arrival scenarios in Section 6.6.1 of this analysis, the overall uncertainty for the CSNF inventory was determined.

The following data qualification was performed in accordance with AP-SIII.9Q, Scientific Analyses, Section 5.2.11. The following factors have been used to show that data are suitable for intended use:

- Reliability of data source

- Extent to which the data demonstrate the properties of interest

- Prior uses of the data.

The average percent difference between measured and calculated radionuclide isotopes was derived using the SCALE (Standardized Computer Analyses for Licensing Evaluation) Code System. The SCALE Code System has been developed by the Nuclear Analysis Methods and Applications (NAMA) Group of the Nuclear Science and Technology Division at the Oak Ridge National Laboratory (ORNL). This work has been ongoing since 1976 for the Nuclear Regulatory Commission (NRC) Office of Nuclear Material Safety and Safeguards (NMSS) and NRC Office of Research. The SCALE code system is composed of control modules (e.g., SAS2H (Shielding Analysis Sequence 2H)), which drive functional modules (e.g., ORIGEN-S) to perform nuclear-related calculations, (e.g., isotope generation and depletion in the case of SAS2H/ORIGEN-S and as those used by this analysis). The major analysis modules and libraries implemented for the SCALE 4.0 release in 1990 had already been used for production quality analyses for at least 10 to 25 years then, and were already widely accepted as qualified by the nuclear industry.

In 1988, during the development of the SCALE 4.0 release, the Department of Energy (DOE) Office of Civilian Radioactive Waste Management (OCRWM) funded the development of a quality assurance program for SCALE, as described in SCALE-QAP-005, Rev.1 (ORNL 2002 [DIRS 170912]). This plan is based on requirements from: DOE Order 5700.6C, Quality Assurance; and ASME NQA-1, Quality Assurance Requirements for Nuclear Facilities (ASME 1986 [DIRS 153446]; as well as on ORNL Standards Based Management System QA requirements.

The SCALE QA Plan is complemented by Configuration Management Plan for the SCALE Code System (Bowman 2002 [DIRS 170913]), which provides configuration control of software for use at ORNL and for release through the Radiation Safety Informational Computational Center to users such as the Yucca Mountain Project. Formal verification and validation (V\&V) of the SCALE code system is controlled by Verification and Validation Plan for the SCALE Code System (Broadhead 1996 [DIRS 170910]).

The versions of the SCALE code system that have been baselined at the Yucca Mountain Project include: SCALE 4.2 (CRWMS M\&O 1996 [DIRS 170914]); SCALE 4.3 (SCALE V4.3, CSCI: 30011 [DIRS 154059]; SCALE V4.3, CSCI: 30011 Addendum [DIRS 154134]) and the current version, SCALE 4.4a (SCALE V4.4a, STN: 10129-4.4A-00 [DIRS 154394]). All of 
these were developed at ORNL under NRC sponsorship, following some approved version of these QA, Configuration Management, and V\&V plans.

Therefore, there is ample evidence as to the reliability of the sources of these data and use throughout the nuclear community. The authors of the subject references and data were among the developers as well as authors of the validation studies for SCALE and were members of the NAMA Group at ORNL. Over 20 publications using SCALE (SAS2H) are available for viewing and download from the on-line Oak Ridge National Laboratory (ORNL) Comprehensive Publications and Presentations Registry (http://lib1.isd.ornl.gov).

The data meets the needs of this analysis for determination of uncertainty factors associated with the CSNF inventory calculations, as it provides isotope depletion statistics provided using well known methods to account for differences between measure and computed composition given as averages and spreads.

Conclusion: Based on an evaluation of the factors identified from AP-SIII.9Q, it has concluded that the data are qualified for its intended use in this report; that the sources for the data and the data themselves provide the desired level of confidence needed for this analysis. These data are qualified here only for this work product and, therefore, no action required by AP-SIII.3Q. However, actions have been taken to update the Document Input Reference System in accordance with AP-3.15Q.

\section{IV.4 QUALIFICATION OF DATA USED FROM SOURCE TERM ESTIMATES FOR DOE SPENT NUCLEAR FUELS (DOE 2003 [DIRS 163377]) AND SOURCE TERM ESTIMATES FOR DOE SPENT NUCLEAR FUELS (DOE 2004 [DIRS 169354])}

A data qualification effort has been conducted for the following data used as direct input to the this analysis and referenced from the reports:

- Source Term Estimates for DOE Spent Nuclear Fuels. DOE/SNF/REP-078, Rev. 0. Idaho Falls, Idaho: U.S. Department of Energy, Idaho Operations Office (DOE 2003 [DIRS 163377]); 2030 Summary Tables from pages D-568 through D-575, estimates of the radiological source terms for spent nuclear fuels owned by DOE. Section 8, "Uncertainty and Error" to provide the uncertainty for the data.

- Source Term Estimates for DOE Spent Nuclear Fuels. DOE/SNF/REP-078 Rev.1. Three volumes. Idaho Falls, Idaho: U.S. Department of Energy, Idaho Operations Office (DOE 2004 [DIRS 169354]): Page 41, estimate of DOE spent nuclear fuel canisters to be used.

- Source Term Estimates for DOE Spent Nuclear Fuels (DOE 2004 [DIRS 169354]) Revision 1 is used as corroborative input to provide updated DSNF radionuclide inventory data published January 2004 and to provide a canister count that includes the uncertainty of the data. These data are compared with the DSNF radionuclide inventory data used in this analysis to validate the inputs used and validate the uncertainty factors developed. The data used in this analysis to develop the inventory comes from Revision 0 of the same report (DOE 2003 [DIRS 163377]). 
The following data qualification was performed in accordance with AP-SIII.9Q, Scientific Analyses, Section 5.2.11. The following factors have been used to show that data are suitable for intended use:

- Reliability of data source

- Qualification of personnel or organizations generating the data

- Extent to which the data demonstrate the properties of interest.

DSNF includes diverse fuels from various experimental, research, and production reactors and consists of several hundred different fuel types that have been stored at several sites over the years. As a result, the availability and completeness of the radionuclide inventories and associated documentation varies considerably for DSNF. A process for creating a conservative estimate of these SNF source terms was developed by a team of experts representing each of the DSNF storage sites. The process relies on precalculated results that are used to provide radionuclide inventories for typical SNFs at a range of decay times. These results are used to develop "templates" that are scaled to estimate the radionuclide inventory of other similar fuels. The templates were generated using ORIGEN-based calculational techniques. Several validation studies, referenced in the report, have been performed to demonstrate the validity of the model and underlying codes used.

The report was produced by the Idaho National Engineering and Environmental Laboratory (INEEL) under contract number DE-AC07-99ID13727 to U.S. Department of Energy for use in the Yucca Mountain Project. The Quality Assurance section states that procedures that implement Quality Assurance Requirements and Description (DOE 2004 [DIRS 171539]) principles were applied to the report. Audits have been performed on the Quality Assurance programs at INEEL by the Office of Civilian Radioactive Waste Management (OCRWM).

OCRWM performed an audit of selected QA program elements of INEEL's Quality Assurance program September 17-21, 2001 (DOE 2001 [DIRS 171371]). Included in the program elements evaluated was software. The results of the audit was satisfactory and effective implementation of the examined portions of the Office of Civilian Radioactive Waste Management (OCRWM) QA program in accordance with Quality Assurance Requirements and Description (QARD) (DOE 2004 [DIRS 171539]) and applicable implementing procedures.

OCRWM performed an audit of selected QA program elements of the INEEL quality assurance program September 23-26, 2002 (DOE 2002 [DIRS 171675]). Included in the program elements evaluated was software. The results of the audit were satisfactory and effective implementation of the examined portions of the Office of Civilian Radioactive Waste Management (OCRWM) QA program with the exception of deficiencies written during the audit. Deficiency Reports EM (O)-03-D-004 through 007 were written because of the audit and closed by 06/25/03.

The reports establish a process for a conservative estimate of DSNF source terms. The process relies on precalculated results that provide radionuclide inventories for typical SNFs at a range of decay times. These results are used as templates that are scaled to estimate radionuclides for other similar fuels. To estimate a SNF source term, an appropriate template is selected to model the production of activation products and transuranics by matching the reactor moderator, fuel cladding and compound and beginning-of-life enrichment. Precalculated radionuclide inventories 
are extracted from the appropriate template for the desired decay period and then scaled to account for differences in fuel mass and specific burnup. By modeling various combinations of reactor moderator, fuel enrichment, fuel compound and cladding, templates have been developed to reasonably model a broad range of DSNFs. The template methodology enables a source term estimate to be completed for virtually any DSNF for decay dates up to 100 years following reactor shutdown.

The inventory estimates from the reports provide both a nominal and a bounding radionuclide inventory estimates for each of the many and heterogeneous types of DSNFs.

Conclusion: Based on an evaluation of the factors identified from AP-SIII.9Q, it has been concluded that the data are qualified for its intended use in this report; that the sources for the data and the data themselves provide the desired level of confidence needed for this analysis. These data are qualified here only for this work product and, therefore, no action required under AP-SIII.3Q. However, actions have been taken to update the Document Input Reference System under AP-3.15Q.

\section{IV.5 QUALIFICATION OF DATA USED FROM 2002 WASTE STREAM PROJECTIONS REPORT (BSC 2002 [DIRS 160059])}

The following data qualification was performed in accordance with AP-SIII.2Q, Qualification of Unqualified Data. The qualification method used is technical assessment and is included as part of this analysis. The technical assessment approach may be taken when it is determined that an independent evaluation of the data by a subject matter expert is needed to raise the confidence of the data to a proper level for the intended use. The rationale for choosing this method is that this report develops project data that cannot be verified at this time. The criteria for this qualification are based on the evaluation of attributes and the determination that the data can be qualified for intended use as it is applied in this report. This qualification does not qualify the input for other analyses or for general use, but is limited to its use in this analysis.

The qualification attributes include: (1) the extent to which the data demonstrate the properties of interest; (2) prior peer reviews and uses of the data and their results and associated verification processes; (3) extent and reliability of the documentation associated with the data; (4) the importance of the data to showing that the repository design meets the performance objectives of 10 CFR Part 63 [DIRS 156605].

A data qualification effort has been conducted for data used by this analysis taken from 2002 Waste Stream Projections Report (BSC 2002 [DIRS 165990]). The data are:

1. Total number of BWR and PWR assemblies for the "63K Case A," "63K Case B," "63K Case C," and "63K Case D" arrival scenarios and methodologies shown in Table 2: CSNF Assembly Total for Discharge Projections of the subject reference. These data are shown in Table 4-6 of this analysis: CSNF Assembly Totals and Characteristics for the 63,000 MTHM Cases and referred to as Cases A' to D'.

2. The average burnup (GWd/MTU) for BWR and PWR assemblies for waste steam scenarios: Case A through Case D from Table 4: "Repository Arrival CSNF Assembly Characteristics for the 63K MTHM Cases" of the reference also shown in Table 4-6 of 
this analysis: CSNF Assembly Totals and Characteristics for the 63,000 MTHM Cases.

The qualification was conducted to determine if these data from 2002 Waste Stream Projections Report (TDR-CRW-SE-000022 REV 01) (BSC 2003 [DIRS 165990]) can be used as a direct input in Initial Radionuclide Inventories (ANL-WIS-MD-000020 REV01). The data used from this reference is used to derive the uncertainty factors to be applied to the average radionuclide inventory for CSNF as calculated in Section 6.6.1. The following justification is provided for this determination.

The reference document, 2002 Waste Stream Projections Report (BSC 2003 [DIRS 165990]), was produced under the Office of Civilian Radioactive Waste Management for the Yucca Mountain Project. The document was not produced as "QA:QA" and although an Activity Evaluation was conducted in accordance with the Technical Work Plan for Design Basis Input for License Application (BSC 2001 [DIRS 157450]), it was determined that the report "was not subject to the requirements based on Quality Assurance Requirements and Description." The inherent nature of the data does not lend itself to direct qualification because it is based on projections using data gathered from a variety of unqualified sources that include various nuclear power utilities. Raw data is originally submitted to the Department of Energy are compiled and Waste Steam Projection Reports are developed as necessary to establish the design basis. Office of Civilian Radioactive Waste Management (OCRWM) has accepted this process for design basis using data provided in these projection reports. The data contained in the reports is generally considered the best available and only available data because it originates directly from the utilities and has traceability to its source.

2002 Waste Stream Projections Report (BSC 2003 [DIRS 165990]) considers scenarios based on the design-basis legal limit of 63,000 MTHM CSNF and 7,000 MTHM government-managed wastes. As noted in the report, the purpose of the report was to provide information on waste stream characteristics and bounding and average waste stream, transportation characteristics as well as waste arrival data at the repository for use in the CRWMS design and development of system level requirements. 2002 Waste Stream Projections Report (BSC 2003 [DIRS 165990]) contains data sets that span the range of possible delivery options for CSNF, governmentmanaged wastes and HLW although the data apply primarily to CSNF. It is noted in the report that "these data capture probable limits of what might occur in the future with regard to fuel selection by the utilities." The report addresses the influence of arrival sequences of CSNF intended to provide insight into design margins for parameters that are affected by the waste stream (BSC 2003 [DIRS 165990], p. 1).

Because much of the data are projections far into the future and that there is no "factual" data to use (i.e., it is recognized that waste characteristic may be different from those described in this document), the data are technically correct in this respect. The use of burnup data from projections based upon current inventory data and applying arrival scenarios to develop uncertainty factors related to the CSNF inventory at the year of projected emplacement is appropriate for the intended use in this model report. The information and data provided in 2002 Waste Stream Projections Report support the conclusion that the data and the methodologies used for this analysis are appropriate. The data demonstrate the properties of interest (burnup projections for the year of projected emplacement; the importance of the data to showing that the 
proposed repository design meets the performance objectives of 10 CFR 60 (uncertainty associated with the CSNF inventory derived using current data and a range of arrival scenarios) all support the conclusion that the data used from this reference are qualified for intended use. Moreover, the report was reviewed and approved for use by the BSC Manager of Projects, Nancy Williams on 4/7/2003 (BSC 2003 [DIRS 165990]).

In conclusion, the Data Qualification Team has concluded that the source for the data and the data themselves provide the desired level of confidence needed for this analysis and based on the criteria and attributes used to evaluate the subject data, these data are qualified for intended use in this report and fulfill the performance objectives of the intended use. The technical expert, who is the technical checker for this analysis, has reviewed this data qualification and confirms that it meets all the requirements of AP-SIII.2.Q.

These data are qualified here only for this work product and, therefore, no action is required in accordance with AP-SIII.3Q. However, actions have been taken to update the Document Input Reference System under AP-3.15Q. 


\section{APPENDIX V}

DATA QUALIFICATION PLAN 
INTENTIONALLY LEFT BLANK 


\section{DATA QUALIFICATION PLAN}

\begin{tabular}{|c|c|c|}
\hline \multirow{2}{*}{ BSC } & \multirow{2}{*}{ Data Qualification Plan } & QA: QA \\
\hline & & Page 1 of 1 \\
\hline \multicolumn{3}{|c|}{ Section I. Organizational Information } \\
\hline \multicolumn{3}{|c|}{$\begin{array}{l}\text { Qualification Title } \\
2002 \text { Waste Stream Projections Report TDR-CWR-SE-000022 REV } 01\end{array}$} \\
\hline \multicolumn{3}{|c|}{$\begin{array}{l}\text { Requesting Organization } \\
\text { Regulatory Integration Team }\end{array}$} \\
\hline \multicolumn{3}{|c|}{ Section II. Process Planning Requirements } \\
\hline \multicolumn{3}{|c|}{$\begin{array}{l}\text { 1. List of Unqualified Data to be Evaluated } \\
\text { The report } 2002 \text { Waste Stream Projections Report, TDR-CWR-SE-000022 REV } 01 \text { provides Waste Package Characteristics: number } \\
\text { of BWR and PWR assemblies (waste packages) and average burnup (GWd/MTH) for arrival scenarios for the } 63,000 \text { MTHM Cases: } \\
\text { A, B, C, and D derived from Tables } 2 \text { and Table } 4 \text {. These data are presented in Table } 4-6 \text { of the Initial Radionuclide Inventories } \\
\text { analysis report, ANL-WIS-MD-000020 REV01. }\end{array}$} \\
\hline \multicolumn{3}{|c|}{$\begin{array}{l}\text { 2. Type of Data Qualification Method(s) [Including rationale for selection of method(s) from AP-SIII.2Q,Attachment } 3 \text { and } \\
\text { qualification attributes, Attachment 4] } \\
\text { Qualification method: Technical Assessment. Documentation or proof of proper data is unavailable for review. } \\
\text { Evaluation of the data and available documentation will be conducted to determine that the employed methodology used for the data } \\
\text { identified is acceptable. The rational for choosing this method is that this report develops projected data that cannot be verified at this } \\
\text { time. This effort is being conducted to ensure the data is acceptable under current QA requirements. } \\
\text { Qualification attributes:: (1) the extent to which the data demonstrate the properties of interest; (2) prior peer reviews and uses of the } \\
\text { data and their results and associated verification processes; (3) extent and reliability of the documentation associated with the data; (4) } \\
\text { the importance of the data to showing that the repository design meets the performance objectives of } 10 \text { CFR Part } 63 \text { [156605] }\end{array}$} \\
\hline \multicolumn{3}{|c|}{$\begin{array}{l}\text { 3. Data Qualification Team and Additional Support Staff Required } \\
\text { Author and Checker (subject matter expert). }\end{array}$} \\
\hline \multicolumn{3}{|c|}{$\begin{array}{l}\text { 4. Data Evaluation Criteria } \\
\text { The data provide the desired level of confidence needed for this analysis and based on the criteria and attributes used to evaluate the } \\
\text { subject data, these data are qualified for intended use in this report and fulfill the performance objectives of the intended use. This } \\
\text { data provides the data on the average burnup (GWd/MTH) and number of packages associated with that burnup for four "Case } \\
\text { Methodologies" used to derive the uncertainty for the inventory. Data is to be used as a direct input in the Initial Radionuclide } \\
\text { Inventories report ANL-WIS-MD-000020 REV01. }\end{array}$} \\
\hline \multicolumn{3}{|c|}{$\begin{array}{l}\text { 5. Identification of Procedures Used } \\
\text { AP-SIII.2Q/Rev.1/ICN2 }\end{array}$} \\
\hline \multicolumn{3}{|c|}{ Section III. Approval } \\
\hline \multicolumn{2}{|c|}{$\begin{array}{l}\text { Qualification Chairperson Printed } \\
\text { Name } \\
\text { Holly Miller }\end{array}$} & $\begin{array}{l}\text { Date } \\
7 / 29 / 04 \\
\end{array}$ \\
\hline $\begin{array}{l}\text { Responsible Manager Printed Name } \\
\text { Neil Brown }\end{array}$ & Responsible Manger Signature & $\begin{array}{l}\text { Date } \\
7 / 29 / 04\end{array}$ \\
\hline
\end{tabular}


INTENTIONALLY LEFT BLANK 